FACULDADE DE ARQUITETURA E URBANISMO UNIVERSIDADE DE SÃO PAULO

MARILI DE LIMA FERREIRA BRANDÃO

DESIGN SUSTENTÁVEL: O USO DA MATÉRIA PRIMA RENOVÁVEL. UM ESTUDO DE CASO DA PRODUÇÃO DO COURO VEGETAL NO NORTE DO BRASIL 
Marili de Lima Ferreira Brandão

\section{Design sustentável: o uso da matéria prima renovável. Um estudo de caso da produção do couro vegetal no norte do Brasil.}

Dissertação de Mestrado apresentada à Faculdade de Arquitetura e Urbanismo da Universidade de São Paulo como exigência parcial para obtenção do título de Mestre em Arquitetura e Urbanismo - área de concentração: Design e Arquitetura, sob orientação da Prof. Dra. Maria Cecília Loschiavo dos Santos. 
AUTORIZO A REPRODUÇÃO E DIVULGAÇÃO TOTAL OU PARCIAL DESTE TRABALHO, POR QUALQUER MEIO CONVENCIONAL OU ELETRÔNICO, PARA FINS DE ESTUDO E PESQUISA, DESDE QUE CITADAA FONTE.

ASSINATURA:

E-MAIL: marili@brasilfazdesign.com.br

B817d Brandão, Marili de Lima Ferreira

Design sustentável: o uso da matéria prima renovável.

um estudo de caso da produção do couro vegetal no norte do Brasil /Marili de Lima Ferreira Brandão.-São Paulo, 2007.

137 p. : il.

Dissertação (Mestrado - Área de Concentração:

Design e Arquitetura) - FAUUSP.

Orientadora: Maria Cecília Loschiavo dos Santos

1.Design( Projeto) - Brasil 2.Projetos de produtos

3.Borracha 4.Áreas de conservação I.Título

CDU 7.05(81) 
é certo que tempos difíceis existem para aperfeiçoar o aprendiz...

sei que não dá para mudar o começo, mas, se a gente quiser, dá para mudar o final.

(Só de Sacanagem - Elisa Lucinda - CD Ana Carolina e Seu Jorge)

Aos meus pais Maria Lygia e Augusto 


\section{AgRADECIMENTOS}

Agradeço a todos que colaboraram para realização deste trabalho:

A minha orientadora Maria Cecília Loschiavo do Santos pela acolhida dada a este trabalho e pelo apoio nos percalços de caminho, permitindo sua finalização.

Aos professores da Universidade de São Paulo que me aceitaram em suas disciplinas possibilitando um entendimento multidiciplinar da complexa questão da sustentabilidade: Prof. Pedro Jacobi da Faculdade de Educação, Prof. Tadeu Malheiros da Faculdade de Saúde Pública, Prof. Isak Kruglianskas da Faculdade de Economia e Administração, Prof. Wagner Ribeiro da Faculdade de Filosofia, Letras e Ciências Humanas, Departamento de Geografia.

Ao Centro São Paulo Design pela possibilidade de freqüentar o Curso da Avaliação de Ciclo de Vida e ao Prof. Gil Anderi da Engenharia Química da Escola Politécnica, que me auxiliou com informações de ACV aplicada a meu estudo de caso.

Aos professores da ESALQ, Marcos Bernardes Silveira pelas informações sobre borracha natural e seringal plantado; e ao Prof. José Nivaldo Garcia por ter acreditado no encaminhamento deste trabalho. Á Henrique Sérvulo Filho pela possibilidade de assistir sua dissertação de mestrado sobre o couro vegetal.

Ao Prof. da Faculdade de Contabilidade da FEA, Gilberto Andrade Martins que me permitiu participar de suas Discussões Metodológicas

Aos Prof. da FAU, Giorgio Giorgi Jr. pela colaboração no exame de qualificação e Chico Homem de Melo pelo incentivo de iniciar o processo de mestrado.

Ao Prof. Giuseppe Lotti da Universidade de Florença, Itália e a prof. Aslaug Mikkelsen da Universidade de Stavanger, Noruega, por confirmarem que a linguagem da sustentabilidade é universal.

Ao Grupo de Meio Ambiente da FIESP pela possibilidade de ter trabalhado na revisão da tradução da ISO 14062 e a Suzana Serrão, do INPI, pelas informações sobre Patente de Invenção.

A Patrícia Gomes, Coordenadora de Certificação Florestal Comunitária e PFNMs do Imaflora, que mostrou ser possível traçar a cadeia produtiva do couro vegetal produzido em Boca do Acre e ao Estevão do WWF-Brasil, pelos esclarecimentos sobre a parceria desta ONG com o Projeto Couro Vegetal da Amazônia.

A Alexandre Goulart de Andrade, autor de dissertação de mestrado pela Unicamp sobre o couro vegetal do Alto Juruá, pelo envio de relatório de visita de campo de autoria de Luis Mario Fujiwara realizado para a Fundação Ford.

A Bia Saldanha da Couro Vegetal da Amazônia e a Wilson Manzoni, ex-presidente da APAS, pela colaboração.

Aos amigos designers Christian Ullmann, Ivo Pons, Gustavo Dias, Vanessa Espínola, Daniela Jardim, Carla Tenenbaum, pelas constantes conversas sobre como o design pode colaborar para construir uma sociedade mais saudável e mais justa.

Ao Tasso Azevedo, diretor do Serviço Florestal do MMA pela introdução ao tema do Manejo Florestal e da Certificação. Á Haroldo de Mattos Lemos, presidente do Instituto Brasil PNUMA, pelas várias conversas sobre sustentabilidade.

Aos ministros José Sarney Filho e Marina Silva por prestigiarem nosso evento Design \& Natureza, confirmando a possibilidade de harmonia entre estes temas. 


\section{RESUMO}

Esta dissertação constitui-se em um estudo do Projeto Couro Vegetal da Amazônia que possui características de um projeto de design sustentável. O trabalho procura demonstrar isto através da conceituação de sustentabilidade aplicada ao projeto de produto sob os ângulos ambiental, social e econômico.

A conceituação foi feita segundo parâmetros internacionais aplicadas ao contexto brasileiro. O estudo tem como ponto de partida o uso e características da matéria prima renovável, a borracha, e seu histórico do ponto de vista do extrativismo, dos conflitos sociais e dos resultados positivos destas lutas a favor dos seringueiros que resultou também em benefícios ecológicos para a preservação das florestas através da criação de Unidades de Conservação de Uso Sustentável que fazem parte das políticas públicas brasileiras atuais. Para medir o impacto ambiental do produto foi estudada a ferramenta de Avaliação de Ciclo de Vida e sua aplicação na fabricação do couro vegetal. O trabalho pretende contribuir para a criação de parâmetros de sustentabilidade aplicados ao design brasileiro que possam servir de referência na atividade de projeto de produto. 


\section{ABSTRACT}

This dissertation is a study of Amazonia Vegetal Leather Project that has caracteristics of "sustainable design". The aim of this work is to demonstrate it, based upon concepts of sustainability considering environmental, social and economic aspects, applied to product project. This approach has been made based in international concepts applied to brazilian reality. The starting point of the study is the use and the caracteristics of the renewable raw material, the natural rubber, its history of extractivism, social conflicts, and the positive results for the "seringueiros" and for the conservation of the forest by the creation of Conservation Units with Sustainable Use that is part of brazilian public politics nowadays. To measure the environmental impacts of the product the Life Cycle Assesstment has been studied and its application to vegetal leather production. The intention of this work is contribute to create parameters of sustainability applied to Brazilian design that can be a reference to the activity of product project. 


\section{LISTA DE FIGURAS}

Figura 1: A volta ao mundo na fabricação de uma calça jeans. Fonte: Kazazian, Tierry, 2003, p. 61 22

Figura 2: Logotipo Rio 92. Design: Evelyn Grumach. Fonte: Catálogo Brasil Faz Design 1995 38

Figura 3: Mapa com localização da Floresta Nacional Mapiá-Inauiní. Fonte: Mapa ISA .... 45

Figura 4: Negócios Sustentáveis na Amazônia. Fonte: Negócios para Amazônia Sustentável, 2002/03

Figura 5: Fotografia da extração do látex da seringueira. Fonte: Catálogo Amazon Life, 2006.

Figura 6: Fotografia de lâminas de couro vegetal secando ao ar livre após processo de vulcanização. Fonte: Catálogo Amazon Life, 2006 66

Figura 7: Mapa das Unidades de Produção de Couro Vegetal da APAS. Fonte: Site APAS, 2007

Figura 8: Fotografia de Produtos da Amazon Life. Fonte: Catálogo Amazon Life.. 91

Figura 9: Comunicação Visual da Amazon Life: Logotipo, capa do catálogo, página inicial do site e cartão de visita

Figura 10: Foto da loja da Amazon Life em Ipanema, Rio de Janeiro. Fonte: Catálogo Amazon Life, 2006

Figura 11: Fotografia de Produtos da Amazon Life. Fonte: Catálogo Amazon Life 92

Figura 12: Esquema do Ciclo de Vida do Produto. Fonte: Kazazian, Thierry, 2003, p.53.

Figura 13: Esquema de etapas críticas para integração dos aspectos ambientais no projeto e desenvolvimento do produto. Fonte: ISO 14.062 96

Figura 14: Esquema Linear Unidirecional da Economia. Fonte: Kazazian, Tierry, 2003, p. 52 98

Figura 15: Esquema de Fluxo Fechado. Fonte: Kazazian, Tierry, 2003, p. 53 99 
Figura 16: Foto de seringueiro banhando tecido de algodão com látex natural. Fonte: Catálogo Amazon Life, 2006 113

Figura 17: Foto de seringueiro defumandotecido dealgodãoem látex. Fonte: Catálogo Amazon Life, 2006 113 


\section{LISTA DE SigLAS}

ABNT Associação Brasileira de Normas Técnicas

ACV Avaliação do Ciclo de Vida

APAS Associação de Produtores de Artesanato de Seringa

BID Banco Interamericano de Desenvolvimento

BNDES Banco Nacional de Desenvolvimento Econômico

BNDESpar Banco Nacional de Desenvolvimento Econômico Participações S.A.

CEMPRE Compromisso Empresarial para Reciclagem

CETEA Centro de Tecnologia de Embalagem

COC Cadeia de Custódia (Chain of Custody)

$\mathrm{CO}^{2} \quad$ Monóxido de Carbono

EPR Extended Producer Responsability

ESD Ecologilly Sustainable Development

ESALQ Escola Superior de Agricultura Luis Evaldo de Queirós

FSC Conselho de manejo Florestal (Forest Stewardship Council)

FSC/BR Iniciativa Nacional do FSC no Brasil

FLONA Floresta Nacional

IBAMA Instituto de Meio Ambiente e Recursos Naturais Renováveis

IDH Índice de Desenvolvimento Humano

ISA Instituto Socioambiental

Imaflora Instituto de Manejo e Certificação Florestal e Agrícola

ISO International Organization for Stantardization

MMA Ministério do Meio Ambiente

ONG Organização Não Governamental

ONU Organização das Nações Unidas

PAS Plano Amazônia Sustentável

PIB Produto Interno Bruto

P\&C Princípios e Critérios do FSC 
PMF Plano de Manejo Florestal

PNMA Programa Nacional de Meio Ambiente

PNUD Programa das Nações Unidas para o Desenvolvimento

PPG7 Programa Piloto de Conservação das Florestas Tropicais do Brasil

RESEX Reserva Extrativista

SGA Sistema de manejo Ambiental

G7 Grupo dos sete países mais ricos do mundo, substituído por G8

SLIMF Manejo Florestal em Pequenas Propriedades e de Baixa Intensidade (Small and Low Intensity Managed Florests)

SNUC Sistema Nacional de Unidade de Conservação

SRI Social Responsible Investing

TR Technical Report

UC Unidade de Conservação

USAID United States Agency for International Development 


\section{SUMÁRIO}

RESUMO

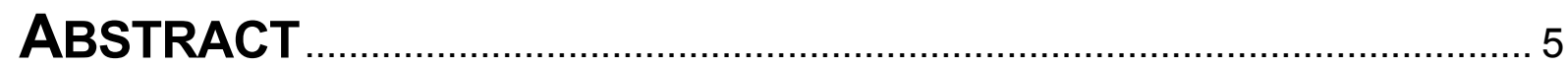

INTRODUÇÃO

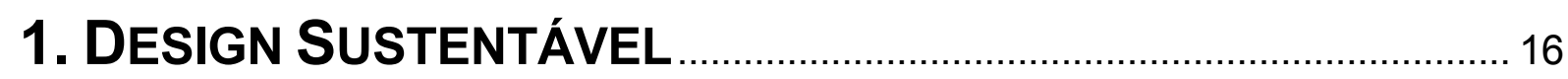

1.1. Questões Conceituais ........................................................................ 16

1.2. Abrangência do design para a sustentabilidade ............................ 18

1.2.1. Considerações sobre tempo e lugar................................................. 19

1.2.2. Aparência e Longevidade ................................................................. 23

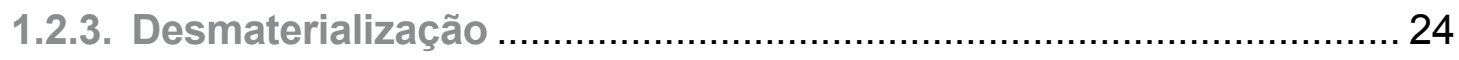

1.2.4. Mais Veloz, Mais Insustentável....................................................... 24

1.2.5. Responsabilidade sobre os Efeitos dos Próprios Atos......................... 25

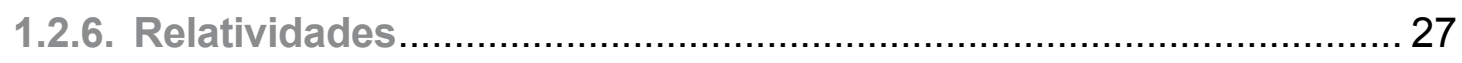

1.3. Design Sustentável no Setor Empresarial Brasileiro ........... 28

1.4. Utopia ou um Projeto Necessário? ................................................ 32

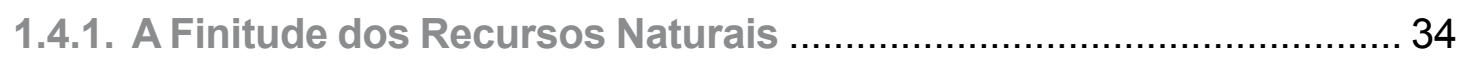

\section{Políticas Públicas Ambientais no BRASIL .........................37}

2.1. Políticas Ambientais e Conseqüências da Rio 92 .................. 37

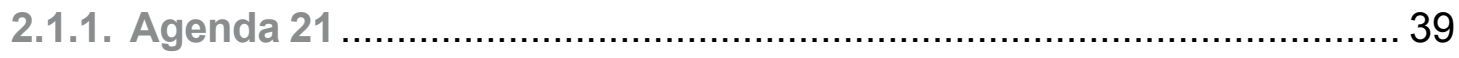

2.1.2. Programa Piloto para a Proteção das Florestas Tropicais do Brasil 40

2.1.3. SNUC - Sistema Nacional Unidades de Conservação.. 44

2.2. SNUC: Preservação das Florestas e Desenvolvimento na

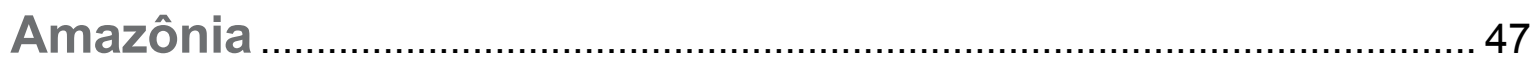

2.2.1. Povos da Floresta ....................................................................... 52

2.2.2. Conhecimento Tradicional............................................................. 54 
2.3. Extração de Madeira e Produtos Florestaís Não Madeireiros .. 64 2.4. Valorização do Conhecimento Tradicional 64

\section{A BORRACHA NATURAL}

3.1. Borracha Natural: matéria prima renovável 57

3.1. Extrativismo e Plantio 59

3.2. Ciclos da Borracha e Movimentos Socioambientais 61

\section{O Couro Vegetal}

4.1. O couro vegetal: aprimoramento do tecido encauchado ...... 66

4.2. Projetos similares ao Couro Vegetal da Amazônia 68

4.3. AAPAS - Associação de Produtores de Artesanato e Seringa da Boca do Acre - Amazonas/ Flona Mapiá Inauní

4.3.1. A Certificação FSC - Forest Stewardship Council ............................. 76

4.3.2. A Certificação FSC da APAS pelo Imaflora ............................................ 82

4.4. A empresa Couro Vegetal da Amazônia e a Amazon Life.... 86

4.4.1. Questões Sociais do empreendimento ............................................. 90

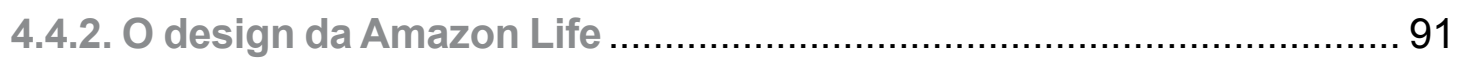

\section{AVALIAÇÃO de CICLO dE VIDA dO PRODUTO .........................93}

5.1. Indicadores de Sustentabilidade ..................................................93

5.2. A ACV - Avaliação do Ciclo de Vida do Produto ...................... 94

5.3. Os desafios para o designer ............................................................... 96

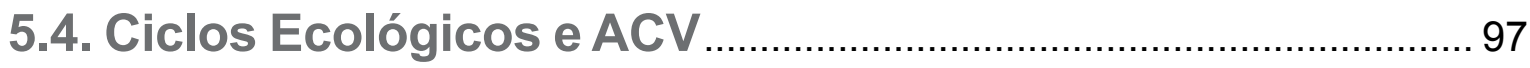

5.5. O Conceito de ACV ......................................................................... 100

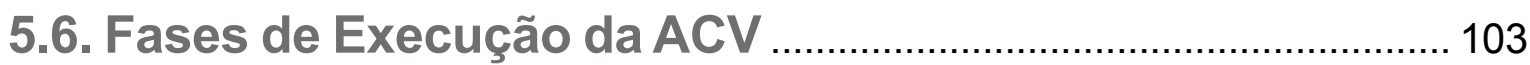

5.7. Informações Qualitativas para ACV do Couro Vegetal .......110 
CONCLUSÃO 124

REFERÊNCIAS BIBLIOGRÁFICAS 129

ANEXOS 135 


\title{
INTRODUÇÃO
}

\begin{abstract}
"Sustentabilidade significa encontrar meios de distribuição dos recursos existentes que sejam sadios, economicamente viável, ecologicamente correto e socialmente justo. Significa garantir qualidade de vida valorizando os bens comuns, o meio ambiente e a comunidade, e reconhecer a interdependência entre eles. O planeta está em grau de manter-se inteiro somente se respeitarmos as exigências da natureza e tornarmos eficientes o uso da tecnologia." (Rogers, 1997, p.166)
\end{abstract}

Para que haja um desenvolvimento com futuro é necessário que seja "sustentável". O conceito de "desenvolvimento sustentável" foi criado para que haja uma convergência entre a sustentabilidade dos seres humanos e os ambientes dos quais eles dependem; impõe uma redução contínua dos impactos dos modos humanos de habitar - seja pensando nas populações atuais seja nas futuras.

Aatividade humana continua criando ambientes artificiais e, encontrar a melhor forma de interação entre o "natural" e o "artificial" é o grande desafio dos profissionais que projetam produtos de design.

O presente trabalho teve por objetivo, através do estudo de caso da produção do couro vegetal no norte do país e sua aplicação na produção de artefatos com este material, apresentar um caminho possível para o desenvolvimento de um design sustentável em território brasileiro, respeitando suas particularidades naturais, suas políticas ambientais e suas carências sociais, porém tendo como base conceitos e instrumentos globais.

O Projeto Couro Vegetal da Amazônia tem como proposta: desenvolvimento, produção, promoção e comercialização do couro vegetal que é um tecido emborrachado com látex natural extraído da seringueira (Hevea brasiliensis) por seringueiros no estado do Acre e Amazonas.

Este trabalho refere-se à produção realizada na área da Floresta Nacional de Mapiá 
Inauiní no estado do Amazonas, coordenada pela APAS - Associação dos Produtores de Seringa e Artesanato da Boca do Acre, coordenada pela Couro Vegetal da Amazônia e comercializada pela Amazon Life, seja em formato de lâmina ou já transformada em produto final: bolsas, pastas, mochilas e bonés.

A escolha deste caso se deu porque o processo de produção deste material envolve questões de grande importância para discussão de sustentabilidade, quais sejam: matéria prima de origem renovável extraída de árvore nativa brasileira, manejo florestal de baixo impacto, certificação florestal, agroextrativismo, conhecimento tradicional, inclusão social e geração de renda, preservação da Floresta Amazônica, baixo consumo de energia, inovação tecnológica, agregação de valor através do design, identidade brasileira e mercado externo.

Esta dissertação está organizada em cinco capítulos. O primeiro capítulo trata de questões conceituais do design sustentável, o segundo de políticas públicas brasileiras com especial interesse aos temas que se referem ao estudo de caso, o terceiro sobre a borracha, matéria prima do estudo de caso e os últimos dois sobre o couro vegetal e avaliação de ciclo de vida, ferramenta capaz de medir os impactos ambientais de um produto desde seu nascimento até seu descarte. No capítulo cinco constam informações iniciais para realização de uma ACV completa do couro vegetal. Futuramente deveria ser feita uma ACV comparativa com outro material com uma mesma função, ou couro animal, ou um tecido emborrachado com material sintético para se ter conhecimento em números do impacto ambiental causado por diferentes produtos. Seria também importante incluir uma visita ao local do extrativismo para conhecer in situ o processo de produção.

A metodologia utilizada foi pesquisa bibliográfica e entrevistas. Dada à atualidade do tema desenvolvimento sustentávele por conseqüência design sustentávelas informações obtidas foram provenientes não só de livros, mas também coletadas através de sites oficiais na internet de entidades governamentais e de ONGs ambientalistas, além de dis 
sertação de mestrado e relatórios de visita de campo realizados por Fujiwara e Allessio para a Fundação Getúlio Vargas e Fundação Ford, e o resumo público do Imaflora para certificação do FSC. Foram coletados dados primários das três partes envolvidas no estudo de caso: a empresária e designer da Couro Vegetal da Amazônia, Maria Beatriz Saldanha, o ex-presidente da APAS (até 2006), Wilson Manzoni, e Patrícia Gomes, do Imaflora que realizou visita de campo em outubro de 2006 para elaboração de relatório anual do Imaflora.

No último capítulo são feitas consideração finais sobre possíveis caminhos do design para colaborar com as mudanças de paradigmas em relação a estilo de vida, avanços tecnológicos e novos modelos de industrialização tendo em mente que Política Ambiental e Desenvolvimento são duas faces da mesma moeda e que Desenvolvimento Sustentável é o que é capaz de conciliar crescimento econômico, preservação do meio ambiente e melhoria das condições sociais. 


\section{Design SustentáVEL}

\subsection{Questões Conceituais}

A palavra "sustentabilidade" passou a ser associada à "ecológica" desde a publicação do "Relatório sobre o Nosso Futuro Comum" (Our Common Future Report ou Relatório Bruntland como ficou conhecido, pois foi coordenado pela então Primeira Ministra da Noruega, Gro Harlem Bruntland, em 1987).

Neste relatório apareceu pela primeira vez a expressão "desenvolvimento ecológico sustentável (ecologically sustainable development - ESD)".

O ecodesign é um modelo de projeto de design orientado por critérios ecológicos. $\mathrm{O}$ tema sintetiza um vasto conjunto de atividades projetuais que envolvem o desenho, ou o redesenho, de um produto destinado a ser produzido em série.

A dificuldade expressa no conceito de "sustentabilidade" está em conciliar a manutenção ecológica , de forma equilibrada e dinâmica, com um conjunto de atividades expansionistas realizadas pelo homem denominada de "desenvolvimento". A característica do desenvolvimento econômico é o crescimento linear, independente da capacidade de regeneração dos recursos naturais necessários para a sua produção. A introdução, no sistema ecológico de ações que alterem de maneira significativa este sistema, cuja característica é a estabilidade de sua dinâmica, faz com que seja desencadeado um processo insustentável.

Para Stuart Walker, professor da Universidade de Calgary, Canadá, hoje seria precipitado tentar encontrar uma solução definitiva para o projeto de design sustentável, pois o tema é vasto e pode ser encarado sob diversos ângulos, além disso, seu estudo está apenas começando. 
O autor reconhece a importância de ferramentas como Avaliação de Ciclo de Vida, Natural Step e Fator 10, porém seu foco de interesse refere-se a contribuição do design em encontrar soluções criativas de estética, aproveitamento de materiais, economia de energia, etc. para resolver os problemas que a sociedade enfrenta do ponto de vista econômico, social e ambiental. Os exemplos de design sustentável apresentado em seu livro Sustainable by Design referem-se a projetos acadêmicos, desenvolvidos sob sua orientação, direcionados para soluções locais e com possibilidades de serem produzidos em pequena série.

Para Tony Fry, diretor da Ecodesign Foundation na Austrália, o ecodesign deve ser entendido dentro de um quadro amplo da sustentabilidade, o que significa ir além do enfoque limitado de materiais e produtos, e deve apontar uma série de aspectos importantes de estratégias a ele relacionados.

Indicado no site da Ecodesign Foundation, com um dos pensadores de design mais importantes da atualidade, Ezio Manzini, do Politécnico de Milão, se apresenta no cenário internacional de maneira mais pragmática. Seu intuito é de contribuir para o desenvolvimento de uma cultura projetual capaz de enfrentar a transição para a sustentabilidade e de promover o aparecimento de uma nova geração de produtos e serviços intrinsecamente mais sustentáveis. O que significa operar no duplo terreno do Life Cycle Design e do design para a sustentabilidade.

Esta é também a opção adotada por este estudo. 


\subsection{Abragência do ecodesign}

Inicialmente o objetivo do ecodesign era mais restrito: referia-se exclusivamente a diminuir o impacto ambiental durante a produção e uso de determinado produto, considerando a utilização de matérias recicláveis ou reciclados e o baixo consumo de energia.

Com a crescente tomada de consciência em relação aos problemas ambientais houve uma mudança de abrangência de enfoque: passou de um tratamento de poluição, com políticas de final de processo (end-of-pipe), para as interferências nos processos produtivos que são geradores desta poluição, as tecnologias limpas e, depois, para o projeto de produtos limpos, e finalmente para a reorientação de comportamento da sociedade em direção à sustentabilidade.

Na prática, segundo Manzini é possível definir quatro níveis fundamentais de possíveis interferências:

- o redesign de produtos já existentes;

- o projeto de novos produtos ou serviços que substituam os atuais;

- o projeto de novos produtos/serviços intrinsecamente sustentáveis;

- a proposta de novos cenários que correspondam a um estilo de vida sustentável.

A possibilidade da realização de um design para a sustentabilidade (design for sustainability), está vinculada a um plano estratégico que envolve a promoção de um novo mercado, diferente do já existente. Além de utilizar tecnologias limpas, o produto deve também ser aceito social e culturalmente. Porém ainda segundo o autor, para que realmente haja uma mudança seria necessário, além de redesenhar produtos e ou gerar novos produtos, atuar considerando outros aspectos como por exemplo o projeto de novos produtos-serviços intrinsecamente sustentáveis ou criando propostas de novos cenários caracterizados por estilos de vida sustentáveis. 
Para que um produto possa ser considerado realmente sustentável, este deveria ser submetido a constantes avaliações comparadas: de implicações ambientais e de diferentes soluções técnicas, sociais e econômicas; além de que deveria considerar todas as condicionantes que determinam seu impacto durante todo seu ciclo de vida pela metodologia conhecida como Life Cycle Design (Design do Ciclo de Vida).

Ou seja, ao se projetar novos produtos deve-se levar em consideração todas as fases do projeto e suas possíveis implicações ambientais ligadas à cada fase do ciclo de vida do produto: pré-produção, produção, distribuição, uso e descarte.

AAnálise do Ciclo de Vida será analisada com mais detalhe no Capitulo 5 deste trabaIho.

\subsubsection{Considerações sobre tempo e lugar}

O desenvolvimento sustentável deve também levar em consideração escalas de tempo e lugar, a necessidade de eqüidade e o bem-estar de todos os seres vivos, sua coexistência com o não vivo em seu espaço vital e compreender a importância da integração, e interdependências, entre as esferas, econômicas e sociais e a biosfera.

O design sustentável além das questões ambientais atende a uma questão de caráter mais fundamental: a de contribuir progressivamente para a capacidade de sustentar-se relacionando-se com ambiente, cultura e economia. A análise de um produto não se restringe a sua forma e funcionamento, mas a uma análise mais ampla que envolve também seu processo de produção. Significa para o profissional da área atuar com maior envolvimento com o estilo de vida, a forma de trabalho, a tecnologia a cultura e a relação entre o tipo de economia, o insustentável e a sustentabilidade. O design passa então a ser um agente potencial de transformação positiva em larga escala. 
A produção de um produto pode ser feita localmente ou globalmente.

Para que haja uma diminuição dos impactos de um produto é necessário desenvolver projetos de design que, dentro do possível, utilizem matérias locais disponíveis, produção em pequena série, e que empregue mão de obra local. Soluções de produção e consumo locais impactantes.

A integração de uma atitude mais local com técnicas mais automatizadas para a produção de produtos de moda pode fornecer um caminho em direção à uma economia de mercado ao mesmo tempo que assegura desenvolvimento e mudanças em direção à práticas que são responsáveis do ponto de vista social e ambiental.

Stuart Walker sugere que objetos podem ganhar em significado se somarmos à utilidade do objeto os benefícios econômicos, ambientais e sociais de sua produção. Para que isto aconteça é necessário uma relação mais profunda com nosso mundo material que, como parece, pode ser encontrado em nível local.

Somar significado transforma a relação do usuário com o produto, cria uma relação com sua história. Se no design e na produção não existirem questões ambientais, éticas e sócio-econômicas ele deixa simbolizar beleza, pois representa um produto nocivo á sociedade. Entretanto podemos encontrar prazer em objetos que possuem significados virtuosos, que representam a criatividade, individual ou coletiva e geração de emprego e renda e prática digna de trabalho.

A beleza pode ser entendida nos objetos através do que ele representa e não somente por sua aparência. Porém a parte criativa, imaginativa, ética e espiritual da sociedade está em desvantagem da parte racional e instrumental. Aênfase no utilitarismo, eficiência econômica, pragmatismo, competitividade agressiva e a idéia do progresso na sociedade atual e do mundo do design limitou, e frequentemente, eliminou a poesia a elegância e a 
austeridade criativa da nossa cultura.

A palavra sustentabilidade evoca idéia de longevidade, continuidade e durabilidade. Produtos globalizados, produzidos em massa inundam o cotidiano das pessoas em diversas partes do mundo. São produtos que não são duráveis, quase sempre fica mais barato descartá-los do que consertar. São um caminho para a insustentabilidade pois faz com que haja um aumento de consumo de energia, matéria prima e aumente o nível de resíduo no mundo.

A maioria dos produtos fabricados em larga escala que buscam o conceito de estética que seguem tendências e modismos escondem por trás da aparência, ações de exploração de recursos naturais, poluição, exploração de mão de obra e disparidade social. Muitas vezes são produtos que para ganhar mercado, através do baixo custo, são produzidos em países que remuneram mal seus empregados, ou são produzidos em empresas de alto nível de automação e alto índice de gasto energético. Utilizam técnicas automatizadas que requerem pouca mão de obra e gastam muita energia na sua produção e na sua distribuição internacional.

O conceito de sustentabilidade não harmoniza com a palavra exploração; baseia-se numa relação respeitosa, responsável e de reciprocidades com pessoas e com o mundo natural. O planeta é um sistema vivo do qual somos dependentes.

É necessário desenvolver projetos de design que, dentro do possível, utilizem materiais locais disponíveis, produção em pequena série, e que empregue mão de obra local. A integração de uma atitude mais local com técnicas mais automatizadas para a produção de produtos pode fornecer um caminho em direção à uma economia de mercado ao mesmo tempo que assegura desenvolvimento e mudanças em direção à práticas que são responsáveis do ponto de vista social e ambiental. 
austeridade criativa da nossa cultura.

A palavra sustentabilidade evoca idéia de longevidade, continuidade e durabilidade. Produtos globalizados, produzidos em massa inundam o cotidiano das pessoas em diversas partes do mundo. São produtos que não são duráveis, quase sempre fica mais barato descartá-los do que consertar. São um caminho para a insustentabilidade pois faz com que haja um aumento de consumo de energia, matéria prima e aumente o nível de resíduo no mundo.

A maioria dos produtos fabricados em larga escala que buscam o conceito de estética que seguem tendências e modismos escondem por trás da aparência, ações de exploração de recursos naturais, poluição, exploração de mão de obra e disparidade social. Muitas vezes são produtos que para ganhar mercado, através do baixo custo, são produzidos em países que remuneram mal seus empregados, ou são produzidos em empresas de alto nível de automação e alto índice de gasto energético. Utilizam técnicas automatizadas que requerem pouca mão de obra e gastam muita energia na sua produção e na sua distribuição internacional.

O conceito de sustentabilidade não harmoniza com a palavra exploração; baseia-se numa relação respeitosa, responsável e de reciprocidades com pessoas e com o mundo natural. O planeta é um sistema vivo do qual somos dependentes.

É necessário desenvolver projetos de design que, dentro do possível, utilizem materiais locais disponíveis, produção em pequena série, e que empregue mão de obra local. A integração de uma atitude mais local com técnicas mais automatizadas para a produção de produtos pode fornecer um caminho em direção à uma economia de mercado ao mesmo tempo que assegura desenvolvimento e mudanças em direção à práticas que são responsáveis do ponto de vista social e ambiental. 


\subsubsection{Aparência e Longevidade}

A questão da durabilidade de um objeto passa pela avaliação de resistência dos materiais, tecnologia e qualidade do envelhecimento do material.

O problema em relação a longevidade de um produto feito em plástico brilhante é quando novo é perfeito porém envelhece mal: fica fora de moda e sua superfície perde a perfeição, então o proprietário é impulsionado a comprar um modelo novo e o ciclo recomeça. Desta maneira o lixo aumenta, o consumo é estimulado e o mundo material é desvalorizado.

Para combater a cultura do descartável seria útil encontrar atitudes alternativas a este modelo de produção e consumo. Se ao invés de conceber produtos que tenham superfícies brilhantes e perfeitas, as irregularidades dos materiais forem aceitas, o envelhecimento deixa de ser um elemento de deterioração do produto a passa a enobrecer, pois conta sua história (diferentemente dos materiais envelhecidos artificialmente). Na verdade precisamos projetar produtos que "envelhecem bem". Por exemplo, produtos de madeira, em relação ao plástico, são mais fáceis de consertar, exigem mão de obra menos especializada é uma matéria prima que quando é danificada é fácil de ser lixada e voltar ao seu estado de novo.

O estilo pode definir a durabilidade de um objeto, pois ele pode ficar "fora de moda" num curto espaço de tempo. As tendências podem colaborar com as vendas de uma empresa, mas frequentemente é um problema para a sustentabilidade. 


\subsubsection{Desmaterialização}

Adesmaterialização visa à redução da utilização de matérias e consequentemente a dissociação do crescimento econômico com o aumento da exploração de matérias-primas. A empresa de economia leve deve aperfeiçoar seus meios, ferramentas de produção e projeto de produtos, para a obtenção de um resultado igual ou até superior ao da estratégia clássica. A desmaterialização é ainda mais adequada em empresas baseadas em valores cada vez mais imateriais, como o domínio do conhecimento científico e tecnológico, as transferências de informação ou as estratégias de organização. Ou seja, a regra é: usar mais raciocínio e menos matéria.

O Fator 4 e o Fator 10 foram concebidos como instrumentos para reduzir os fluxos de matérias-primas na economia: uma divisão por 4 em vinte anos e por 10 em cinqüenta anos. Respeitar estes princípios significa conceber e produzir objetos cotidianos com 4, ou 10, vezes menos matérias primas. A dificuldade em colocar o Fator 4 em prática é menos uma problema de ordem tecnológica do que econômica e psicológica.

\subsubsection{Mais Veloz, Mais Insustentável.}

É possível traduzir o progresso alimentado à combustível fóssil com a expressão "mais rápido". Até hoje a idéia que prevalece é que velocidade maior é melhor que menor. Porém para se obter alta velocidade é necessário pagar um preço. O deslocamento no espaço e no tempo requer deslocamento da natureza. Veículos e combustíveis, estradas e pistas para aviões, aparelhos eletrônicos e eletricidade requerem um gigantesco fluxo de energia material.

É possível melhorar a eficiência do combustível porém, não é possível negar a lei que rege a física da velocidade: para vencer o atrito e a resistência do ar é necessário, em 
maneira não proporcional, grande quantidade de energia.

Além disto, a transmissão eletrônica à velocidade da luz pode levar a um congestionamento de tráfico. É provável que será necessário controlar a velocidade para que a sociedade da informação seja sustentável.

É difícil que uma sociedade que quer se movimentar cada vez mais velozmente seja também sustentável do ponto de vista ambiental.

\subsubsection{Responsabilidade sobre os Efeitos dos Próprios Atos}

Em 1979 Hans Jonas, constatando os abusos da civilização tecnicista e suas conseqüências na exploração da natureza sem responsabilidade teorizou o princípio da precaução. Este princípio e se baseia em atos de prudência e bom senso: toda ação gera uma série de riscos e a vigilância sobre ela é indispensável.

A precaução consiste em ampliar a percepção do desenvolvimento em relação à complexidade dos sistemas que regem a natureza e de questionar as "certezas" existentes.

Em determinado momento ficou claro que a pesquisa científica não era mais suficiente para garantir a inocuidade de uma ação determinada através de uma escolha. Até as decisões mais racionais podem influenciar o futuro de forma negativa. Exemplo disto foi a substituição, em 1940, do gás propano pelo CFC e somente quarenta anos depois foi possível identificar os efeitos altamente destruidores deste gás na camada de ozônio da estratosfera.

O princípio da precaução se aplica à todas as formas de estrutura, tanto políticas quanto institucionais ou industriais. 
Indivíduos, organizações e governo devem assumir as conseqüências de seus atos. O resultado prático desta teoria foi a criação do princípio do "poluidor-pagador" em que o Estado responsabiliza quem está na origem da poluição. É verdade que nem sempre é fácil localizar de quem é a responsabilidade devido a complexidade dos sistemas econômicos.

Uma das interpretações dessa responsabilidade está presente no mercado de cotas de carbono: uma empresa ou país industrializado financia um projeto "limpo" em outro país, obtém créditos e a "permissão para poluir". Na verdade são mecanismos paliativos para poder atingir os objetivos do protocolo de Quioto, mas não substituem os compromissos assumidos em acordos internacionais.

As empresas muitas vezes são reponsáveis por danos ambientais graves e por isso desempenham um importante papel na transformação em direção à sustentabilidade. Durante muito tempo a empresa foi vista como um modelo linear em um sistema composto por ela mesma, seus fornecedores e seu mercado, sobre os qual ela deveria ser capaz de exercer um domínio unilateral. Atualmente é representada como uma célula ativa no meio de um conjunto de relações com o meio ambiente que interage.

Algumas empresas interagem com o meio ambiente como uma oportunidade na sua estratégia de desenvolvimento. A aplicação de métodos de antecipação, gestão das conseqüências, compreensão das interações mudou a visão que tinham de si mesmas a de suas atividades. Desta maneira reduziram a quantidade de matéria prima empregada, o volume de resíduo depositado nos aterros, a utilização de energia através de um uso mais eficiente. Esta abordagem chamada de "ecoeficiente" permite um ganho ambiental ao mesmo tempo que aumenta o lucro para a empresa.

Certificações voluntárias, baseados nos modelos internacionais de gestão de qualidade, "selos" de gestão ambiental do meio ambiente industrial foram elaborados no anos 90 . 
Atualmente milhares de indústria no mundo exibem sua adesão às normas ambientais da série ISO 14 000. A certificação pode se transformar em um item de competitividade e evitar possíveis barreiras comerciais, uma vez que quando é criada uma norma internacional ela pode se tornar restritiva a determinados produtos.

A tendência de estender a responsabilidade do produtor também às fases finais da vida do produto (EPR - Extented Producer Responsability) é uma das mudanças mais significativas em termos de normas atuais no cenário internacional.

\subsubsection{Relatividades}

Experiências têm mostrado que as melhores soluções são específicas para o produto a para a empresa. É necessário encontrar a estratégia adequada para integrar aspectos ambientais no design de produto. Algumas decisões podem ser benéficas se analisadas de um determinado ponto de vista, mas impactar de maneira negativa de outro. É o chamado efeito boomerang. (rebound effect).

Algumas escolhas que, tecnicamente, à primeira vista parecem positivas para o ambiente, quando colocadas em prática se revelam geradoras de novos problemas. Por isso para a tomada de decisões é importante considerar as análises compensatórias (trade-off) que segundo a ISO TR 14062 podem ser de três tipos:

- Trades offs entre diferentes aspectos ambientais

Ex.: A redução de matéria de um produto pode afetar sua reciclabilidade, ou sua durabilidade tornando-o descartável. Com a diminuição da matéria prima, o preço diminui, aumenta o consumo e na prática há um maior consumo de matéria prima. O computador é um meio digital, porém a facilidade de adquirir impressora fez com que houvesse maior consumo de papel. 
- Trade offs entre benefícios econômicos, sociais e ambientais

Ex.: Fazer produtos robustos pode impactar negativamente no que se refere ao uso de maior quantidade de matéria prima e aumentar o custo inicial, porém agrega valor em imagem e durabilidade.

- Trade offs entre aspectos ambientais, técnicos e/ou de qualidade

Ex. aumentar a durabilidade é bom porém em certos produtos pode acarretar prejuízos de consumo de energia. Novas tecnologias podem trazer benefícios de perfomance do produto e fazer com que gaste menos energia. Produtos descartáveis não são aconselháveis, porém utilizar copinhos de plásticos descartáveis e recicláveis pode gerar economia de água e evitar uso de detergente poluidor.

Estas questões fazem parte de um complexo sistema econômico, social, cultural e tecnológico que interferem na esfera individual e social. As transições tecnológicas carregam com elas a imprevisibilidade das suas conseqüências no ambiente sócio-cultural.

\subsection{Design Sustentável no Setor Empresarial Brasileiro}

Como já foi dito anteriormente, a dificuldade expressa no conceito de "sustentabilidade" é a de conciliar a manutenção do ambiente ecológico com o conjunto de atividades expansionistas do "desenvolvimento". Esta dificuldade ganhou ainda mais divulgação no Brasil, quando o presidente Lula, empenhado em aumentar o índice de crescimento de país declarou que "questões ambientais" eram um entrave ao desenvolvimento do país.

$\mathrm{Na}$ análise de diversos especialistas, economistas, cientistas sociais e ecologistas, com este foco o governo se concentra apenas no crescimento econômico e, por isso, é desprovido de uma visão sistêmica acerca do desenvolvimento como um todo. 
Fernando Almeida, professor adjunto da UFRJ e presidente da CEBDS - Conselho Empresarial para o Desenvolvimento Sustentável afirma que quem está na frente da corrida por compreender, assimilar e aplicar os conceitos do desenvolvimento sustentável em todas as suas esferas são as empresas.

Um, ainda pequeno, grupo de empresários, entendeu que as empresas tem um importante papel na transformação em direção à sustentabilidade e que cumprir a lei já não é o suficiente. Ações voluntárias por parte das empresas evolvendo conceitos de "ecoeficiência" proporciona ganho ambiental ao mesmo tempo que gera aumento de lucro.

Segundo Fernando de Almeida, para a classe empresarial a conscientização da necessidade da aplicação dos conceitos da sustentabilidade em larga escala é questão de sobrevivência. Da própria sobrevivência”.

Sem a pretensão de analisar os resultado efetivos das iniciativas, vale citar que tem aumentado em número as ações empresariais em direção a sustentabilidade, com destaque para a atuação do Instituto Ethos, do Depto. de Meio Ambiente da FIESP/CIESP, e a criação do Índice de Sustentabilidade Ambiental da Bovespa, coordenado pela FGV - Fundação Getúlio Vargas.

O ISE - Índice de Sustentabilidade Empresarial é um índice de ações que procura estabelecer um referencial para os investimentos socialmente responsáveis. A tendência de investidores procurarem empresas socialmente responsáveis, sustentáveis e rentáveis para aplicar seus recursos teve início há alguns anos. Estas aplicações, denominadas "investimentos socialmente responsáveis" (SRI), consideram que empresas sustentáveis geram valor para o acionista no longo prazo, pois estão mais preparadas para enfrentar riscos econômicos, sociais e ambientais. O Dow Jones foi a primeira instituição a incorporar sustentabilidade no mercado de ações: o Dow Jones Sustainability Index (Índice Dow Jones de Sustentabilidade). 
O Centro São Paulo Design, mantido pelo IPT, FIESP/CIESP, Sebrae e Secretária de Ciência e Tecnologia do Estado de São Paulo é o parceiro da FIESP no que se refere ao tema design sustentável.

\begin{abstract}
"Design Sustentável é a ferramenta que intensifica, aprimora e amplia os objetivos originais de design e seu respectivo raio de ação, através de produtos, serviços, processos, sistemas e estratégias, agindo em comunhão com o conceitos de desenvolvimento sustentável seguindo as metas estabelecidas internacionalmente para este fim. (Fábio Souza, 2004, site Centro São Paulo Design).
\end{abstract}

O design sustentáve/ procura otimizar o uso da ferramenta do design com o objetivo gerar possibilidades de melhoria da qualidade de vida do indivíduo numa evolução sustentável - garantindo a continuidade do processo nos mesmos patamares de seu início.

A atividade do design sustentável acompanha a direção das metas traçadas em convenções internacionais sobre o futuro das políticas públicas em benefício do planeta, nas dimensões sociais, ambientais e econômicos. São exemplos: Protocolo de Quioto, Agenda 21, Metas do Milênio, Programa Piloto de Preservação das Florestas Tropicais e conceitos emergentes como Responsabilidade Social, Inclusão Digital, Comércio Justo, Mudanças Climáticas.

Através da ecoeficiência é possível a obtenção de serviços com preços competitivos que satisfazem as necessidades humanas e trazem qualidade de vida reduzindo progressivamente os impactos ambientais através de todo o ciclo de vida para um nível, no mínimo, alinhado com a capacidade que a Terra tem de suportar. (WBCS - World Business Council for Sustainable Development)

Quando, em 1997, a Federação das Indústrias do Estado de São lançou o Prêmio Ecodesign: um prêmio à competitividade com design e princípios ecológicos, um sinal concreto de que as preocupações ecológicas unidas ao design entrava na agenda das indústrias brasileiras, foi dado. 
É sabido que empresários trabalham com números e resultados e que os melhores trabalham com planejamento a longo prazo. Na época o então presidente da instituição, Horácio Piva Lafer afirmava em texto publicado sobre o concurso:

o desenvolvimento de produtos de acordo com princípios ambientais tornou-se um dos pré-requisitos de competitividade. A indústria que, com raras exceções encarava as questões ambientais como um problema, custoso de ser resolvido e a legislação como entrave hoje transforma estas questões como um desafio de transformar problemas em oportunidade de negócios. A indústria que por outro lado era vista, de maneira simplista, como sendo uma atividade eminentemente poluidora, tem incorporado o paradigma ambiental e encontrado caminhos e soluções eficazes para inserção de novos critérios na produção industrial.

"o ecodesign incorpora tecnologias, materiais e processos produtivos modernos, usando-os de forma adequada e em conformidade ambiental, com vantagens competitivas excepcionais para a indústria, com otimização de processos, economia de recursos e eliminação de desperdícios, contribuindo para viabilizar uma relação mais harmônica entre sociedade e meio ambiente. Significativamente o ecodesign abre perspectivas realistas para os nossos recursos e peculiaridades econômicas e socioculturais, gerando produtos com design diferenciado e identidade marcante, associado à biodiversidade $e$ à responsabilidade para com as futuras gerações e, simultaneamente, capazes de se consolidar em mercados mundiais mais exigentes.".

Para Angelo Albiero Filho, então Diretor Titular do Departamento de Meio Ambiente e Desenvolvimento Sustentável da FIESP/CIESP

\begin{abstract}
"a velocidade da globalização, o fortalecimento da consciência ambiental, as pressões e legislações correlatas, assim como o espaço que o tema vem recebendo na mídia, acelera o desenvolvimento da cultura sobre o tema no setor industrial de todo país, seus benefícios e aplicações, assim como o desenvolvimento de ferramentas técnicas e metodológicas.".
\end{abstract}

A predominância inicial era o aproveitamento de resíduos e a reciclabilidade dos materiais porém as diretrizes mais recentes enfatizam soluções que enfocam economia de energia, o uso sustentável das matérias-primas, a redução de componentes, a separação de materiais para facilitar seu aproveitamento posterior, a substituição de materiais poluidores por outros ambientalmente mais adequados, a extensão da vida útil dos produtos, entre outras questões. 
Para Angelo Albiero o Brasil, ao aproveitar de forma sustentável suas incontáveis riquezas naturais, tem imenso potencial competitivo no mercado interno e no exterior. É necessário promover um esforço de mobilização de diversos setores envolvidos e uma postura pró-ativa em relação ao tema.

Atualmente O Departamento de Meio Ambiente e Sustentabilidade da Fiesp trabalha na tradução das Normas da Série ISO 14000, Sistema de GestãoAmbiental(SGA), Rotulagem Ambiental de Produto, ACV - Avaliação de Ciclo de Vida, Mudanças Climáticas, Barreiras Técnicas Ambientais ao Comércio, e, Integração de Aspectos Ambientais em Normas e em Projeto de Desenvolvimento de Produtos.

\subsection{Utopia ou um projeto necessário?}

A tecnologia cria a interação entre o "natural" e o "artificial".

A insustentabilidade acontece quando atingimos o ponto crítico nesta relação, quando a velocidade da utilização do "capital da sustentação" (aquele do qual dependemos) ultrapassa sua capacidade de renovação, regeneração, reparo ou recriação de tais "ativos".

A população do planeta passou de 1,6 bilhões de pessoas em 1900, para mais de 6 milhões nos dias de hoje. Desde o início da Revolução Industrial a utilização de recursos e a capacidade de produção, bem como o consumo e o desperdício cresceram continuamente.

Uma sociedade incapaz de ver as implicações de seus atos e que se recusa a enfrentar o que muitas vezes, empiricamente, é evidente torna o desenvolvimento "insustentável". O problema está no centro das economias industriais, da sociedade de consumo e do modo que vivemos e sonhamos. 
Ao manter o mesmo modelo de vida já estabelecido o homem caminha para um mundo de recursos esgotados, ambientes degradados, ecologias danificadas e um sistema disfuncional de valores, que aparentemente faz parte da "natureza humana".

Alguns teóricos acreditam que novas tecnologias podem, em algum momento, resolver todos os problemas.

Para Tony Fry esta crença está equivocada. Apesar da tecnologia poder resolver certos problemas ela é também capaz de aumentá-los. Através da tecnologia tem sido possível uma crescente capacidade produtiva que alimenta a sociedade de consumo; quando uma nova tecnologia é criada, muitas vezes, não é possível prever seu impacto futuro como, por exemplo aconteceu com o uso do automóvel e a engenharia genética. Outra questão que se apresenta é que muitos problemas ambientais não se referem exclusivamente ao domínio da tecnologia. O aquecimento global, gerado em grande parte pela emissão de gases, não se resolve somente por técnicas de redução ou substituição, apesar deste ser um grande desafio. É também necessário comprometimento político e mudanças culturais. O caminho que os países em desenvolvimento procuram trilhar é o de um desenvolvimento industrial e cultural baseado em uma economia apoiada em consumo energético e aumento de emissões de gases de efeito estufa. Asustentabilidade só poderá ser alcançada ser houver uma ampla redução de impactos, justiça social e novos imaginários, que permitam a humanidade realizar seus sonhos sem que haja uma constante destruição ambiental.

Estamos num grau de desenvolvimento que apesar de dependermos da natureza, não é mais possível voltar a uma vida "natural", porém é necessário repensar a relação entre o "natural" e o "artificial" e reconhecer que os antigos, e os não modernos, sabiam, e ainda sabem no caso de populações tradicionais, mais sobre seus ambientes do que a civilização contemporânea. 
A sustentabilidade é um processo necessário para garantir o futuro da humanidade, no qual a adaptação é possível. É parte de um tempo de mudanças. Não será alcançada somente com um passo, nem desvinculada de uma teoria e de um valor. O ecodesign, ou o design sustentável é somente uma das ferramentas deste processo.

\subsection{A Finitude dos Recursos Naturais}

O homem recorre aos recursos naturais, isto é, aqueles que estão na Natureza, para satisfazer suas necessidades, porém, enquanto que a população continua a crescer o planeta Terra é um sistema limitado.

Hoje estamos mais conscientes sobre os impactos negativos da atividade humana sobre o meio ambiente, porém os danos ambientais não são um fenômeno recente. Já no século XVI, com o desenvolvimento da indústria do aço, houve uma destruição maciça das florestas na Europa.

Os impactos negativos se agravaram nas últimas quatro décadas uma vez que as conseqüências locais de produção e consumo se transformaram em escala universal através da globalização.

Os recursos naturais podem ser renováveis, isto é, voltarem a ser disponíveis, ou não renováveis, isto é, nunca mais ficarem disponíveis. Conservar os recursos naturais implica em usá-los de forma econômica e racional para que, os renováveis não se extingam por mau uso e os não renováveis não se extingam rapidamente.

As matérias primas renováveis são produzidas pela natureza e transformadas pelo homem. Seu tempo de renovação é inferior ou igual ao de uma vida humana. Trata-se de materiais de origem vegetal ou animal, como a madeira, o algodão ou a lã. Uma gestão 
adequada de produtos florestais e provenientes da agricultura assegura sua regeneração. Ao escolher matérias primas certificadas é possível ter certeza que são provenientes de um bom manejo.

As matérias primas não-renováveis se encontram em quantidade limitada na natureza. Os minerais, como por exemplo o minério de ferro, são classificados como recursos naturais não renováveis. Outro exemplo é o petróleo. São recursos não renováveis porque, se utilizadas de forma intensiva, um dia, irão se esgotar no Planeta. Por isso é importante, no caso de matérias primas não renováveis sempre que possível, utilizar material reciclado. No caso da água é preciso reaproveitá-la ao máximo e, quanto menos for poluída mais fácil será purificá-la para sucessivas utilizações.

Se o recurso natural não renovável for reciclado de maneira conveniente é possível haver uma dilatação do prazo de existência desse recurso na natureza.

Segundo o conceito da pegada ecológica (ecological footprint) que mostra impacto de uma pessoa, uma empresa, uma cidade, a humanidade já está vivendo além de seus limites (Beyond the Limits, Mesdows et. al., 1973) e já está utilizando o capital ecológico que é a base para a saúde continuada do planeta. Para satisfazer as necessidades da população mundial vivendo conforme os padrões europeus seriam necessários dois planetas e meio e segundo os padrões americanos cinco planetas.

Sendo assim a gestão de recursos naturais se torna uma questão vital na economia e não haverá uma nova economia sem que hajam novos modelos de vida.

Considerando que: a produção industrial parece crescer de forma inexorável, a população do planeta continua a aumentar, os países em desenvolvimento procuram se industrializar segundo o modelo de bem estar dos países industrializados, o planeta Terra é um só e os recursos naturais são finitos concluímos que o consumo deve ser crítico e 
responsável pois um planeta só não é suficiente para responder às exigências, atuais e futuras, da população humana. Para atingir a sustentabilidade o ser deve prevalecer sobre ter; ter deve servir a ser. A sociedade deverá privilegiar serviços ao invés de produtos. 


\title{
2. Políticas Públicas Ambientais no Brasil
}

\subsection{Políticas Ambientais e Conseqüências da Rio 92}

A política ambiental é o conjunto de decisões estratégicas que visam promover a conservação e o uso sustentável dos recursos naturais.

\begin{abstract}
A ordem internacional é um conjunto de convenções internacionais que busca regular as ações humanas sobre o ambiente em escala internacional. Cada documento firmado prevê a maneira pela qual ocorre a participação das partes - países que assinaram a convenção, que a ratificaram, seja por ato presidencial ou do monarca, seja pela ratificação do Congresso -, a periodicidade das reuniões e eventuais sanções a que estão sujeitas aqueles que não cumprirem os termos acordados. A ampla maioria desses tratados internacionais é resultado de eventos promovidos pela Organização das Nações Unidas - ONU. (Ribeiro, 2003, p. 601 ).
\end{abstract}

Devido à gravidade dos problemas ambientais a importância dada às questões relativas a este tema aumentou. As Conferências Internacionais de Meio Ambiente colocaram a questão socioambiental definitivamente na pauta das preocupações prioritárias mundiais. A primeira reunião da ONU sobre meio ambiente ocorreu em Estocolmo Suécia em 1972 e dela resultou a criação do PNUMA Programa das Nações Unidas para o Meio Ambiente.

As questões de sustentabilidade social e ambiental foram incluídas nas discussões públicas de desenvolvimento e temas como transporte, energia, comércio e indústria passaram a interagir com o setor ambiental. Nesta interação transversal o desafio tem sido o de conciliar interesses que muitas vezes são conflitantes: o da preservação ambiental de um lado e o expansionismo econômico de outro que movimenta setores como mineração, agropecuária, setor imobiliário.

No Brasil as primeiras iniciativas governamentais de gestão ambiental datam do século XIX, com a criação do Jardim Botânico, no Rio de Janeiro, e do Serviço Florestal extinto 
1959 e sucedido pelo Departamento de Recursos Naturais Renováveis e, em 1967, pelo Instituto Brasileiro de Desenvolvimento Florestal (IBDF). Em 1973 foi criada a Secretaria Especial do Meio Ambiente (SEMA) no âmbito do Ministério do Interior.

A criação do Ministério do Desenvolvimento Urbano e Meio Ambiente se deu em 1985, e do IBAMA - Instituto Brasileiro de do Meio Ambiente e dos Recursos Naturais em 1989, que fundiu a Sema à Superintendência do Desenvolvimento da Pesca (Sudepe) e ao IBDF, vinculados ao Ministério da Agricultura à Superintendência da Borracha (Sudhevea). Em 1999 as questões ambientais passaram a ser tratadas no âmbito de uma Secretaria Especial da Presidência República e finalmente, em 1992, foi criado o Ministério do Meio Ambiente, no mesmo ano em que foi realizada a Conferência das Nações Unidas para o Meio Ambiente e Desenvolvimento, a Rio 92, como ficou conhecida.

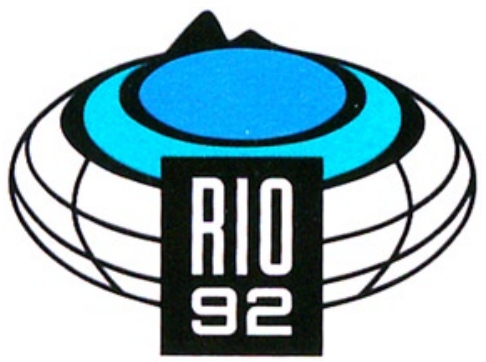

Figura 2: Logotipo
A Rio 92 faz parte de um calendário de conferências internacionais organizadas pela ONU com o objetivo de tratar de problemas internacionais de caráter econômico, social, cultural, ambiental e humanitário.

A Rio 92 pode ser considerada um marco histórico importante na política ambiental brasileira e internacional. Prova disto é que durante sua realização estiveram presentes 118 governantes mundiais, entre eles os presidentes do Brasil e dos EUA, e 15 mil ONGs provenientes de vários países que celebraram um pacto em defesa da justiça social e do meio ambiente resultando na criação do Fórum Brasileiro de ONGs e Movimentos Sociais para o Meio Ambiente e Desenvolvimento. 
Entre os documentos firmados Rio 92 estão: a Declaração sobre Meio Ambiente e Desenvolvimento, a Convenção da Diversidade Biológica, a Declaração de Princípios sobre o Uso das Florestas, a Convenção sobre Mudanças Climáticas e a Agenda 21. Os parâmetros estabelecidos nestes documentos passaram a ser referência para definição de políticas públicas dos países participantes.

Em 2002 foi realizada em Joannesburg, África do Sul, a Cúpula Mundial sobre Desenvolvimento Sustentável, a Rio+10. Porém o que deveria ser uma consolidação dos propósitos estabelecidos na Rio 92, se transformou na elaboração de um documento com metas genéricas e sem previsão de prazos.

Neste mesmo ano o Ministério do Meio Ambiente finalizou a Agenda 21 nacional. Foram então consolidados mecanismos de participação da sociedade nos programas de governo. São exemplos desta cooperação o PP-G7 Programa Piloto para Conservação das Florestas Tropicais do Brasil e o PNMA - Programa Nacional do Meio Ambiente que fortaleceu a estrutura institucional, legal e normativa das políticas ambientais.

\subsubsection{Agenda 21}

A Agenda 21 é um instrumento importante de reconversão da sociedade industrial em direção a um novo paradigma, que exige a reinterpretação do conceito de progresso, contemplando maior harmonia e equilíbrio holístico entre todas as partes, promovendo a qualidade e não apenas a quantidade do crescimento. É um plano de ação para ser adotado global, nacional e localmente, por organizações do sistema das Nações Unidas, governos e pela sociedade civil, em todas as áreas em que a ação humana impacta o meio ambiente.

A Agenda 21 Brasileira foi construída a partir das diretrizes da Agenda 21 Global e 
tou com participação de representantes da sociedade brasileira. Hoje faz parte do Plano Plurianual do Governo o que confirma sua importância como política pública. É um instrumento de planejamento participativo para o desenvolvimento sustentável e tem como eixo central a sustentabilidade, compatibilizando conservação ambiental, justiça social e crescimento econômico.

As ações prioritárias são programas de inclusão social, sustentabilidade urbana e rural, preservação dos recursos naturais e minerais, estímulo ao consumo responsável e ética na política.

Desde sua adoção a Agenda 21 tem sido ajustada e revista. Primeiro na Rio +5 em Nova Iorque, depois com a redação das Metas do Milênio com ênfase na erradicação da fome e nas políticas de globalização e em 2002 na Rio +10 realizada em Joannesburgo.

\subsection{2 - Programa Piloto para a Proteção das Florestas Tropicais do Brasil}

O Programa Piloto foi proposto na reunião do Grupo dos Sete Países industrializados (ex G7) em Houston, EUA, em 1990. Foi aprovado em conjunto com a Comissão Européia em dezembro de 1991. Em 1992, durante a conferência das Nações Unidas para o Meio Ambiente e o Desenvolvimento o programa foi lançado oficialmente pelo Brasil. Uma segunda fase do programa foi iniciada em 2003 e deverá se estender até 2010.

O Programa Piloto para a Proteção das Florestas Tropicais do Brasil é uma ação conjunta dogoverno brasileiro, da sociedade civil brasileira e da comunidade internacional, que busca formas de conservar as florestas tropicais da Amazônia e costa brasileira. Conservar significa tanto proteger as florestas quanto promover o desenvolvimento sustentável da região - para satisfazer as necessidades da geração atual sem comprometer 
as necessidades das gerações futuras.

As florestas tropicais brasileiras oferecem benefícios para o Brasil e para o mundo. As florestas abrigam uma grande diversidade de plantas e animais; armazenam carbono que, se fosse liberado contribuiria para a formação de gases do efeito estufa; regulam ciclos hídricos e preservam o clima da região. O Brasil também tem interesse legítimo em usar este recurso natural como oportunidade econômica que ele representa para a população silvícola e para a nação como um todo. Assim o objetivo do Programa é o desenvolvimento de estratégias inovadoras para a proteção e o uso sustentável da Floresta Amazônica e da Mata Atlântica, associadas à melhoria na qualidade de vida das populações locais. É o maior programa de cooperação multilateral relacionada a uma temática ambiental de importância global.

Para maximizar os benefícios ambientais da floresta de forma e ser consistente com as metas de desenvolvimento do Brasil e de sua população, reduzindo de maneira contínua o índice de desmatamento é necessário:

- demonstrar a viabilidade da harmonização dos objetivos ambientais e econômicos nas florestas tropicais;

- ajudar a conservar os enormes recursos genéticos que as florestas dispõem;

- contribuir para diminuir a participação das florestas brasileiras na emissão de CO2 através do desmatamento.

- servir como exemplo de cooperação entre países desenvolvidos e em desenvolvimento para resolução de questões ambientais globais.

O Programa é financiado por doações dos países integrantes de ex-Grupo dos Sete, da União Européia e dos Países Baixos, complementadas com contrapartida crescente do governo Federal, dos governos estaduais e de organizações da sociedade civil. $O$ Ministério do Meio Ambiente - MMAé responsável pela sua coordenação geral. O plane 
jamento e execução das atividades envolvem parcerias com órgãos do governo federal, governos estaduais e municipais, movimentos sociais, organizações ambientais e setor privado.

O desafio do governo é a implantação de um novo modelo de desenvolvimento na região amazônica, pautado na inclusão social com respeito à diversidade cultural, no fomento a atividades econômicas dinâmicas e competitivas e no uso sustentável dos recursos naturais numa região caracterizada historicamente por uma exploração não sustentável dos recursos naturais da região, relacionados muitas vezes a expansão e colapso de ciclos econômicos, conflitos sociais e de posse de terra.

O governo brasileiro criou em 2003 o PAS - Plano Amazônia Sustentável que envolve cinco temas principais: Ordenamento Territorial e Gestão Ambiental, produção Sustentável com Inovação e Competitividade, inclusão Social e Cidadania, Novo Modelo de Financiamento e Infra-estrutura para o Desenvolvimento.

Desde o início de sua implementação, o que ficou claro, é que os projetos devem ser além de ecologicamente corretos, também política e economicamente sustentáveis. Os projetos que visam mudar a maneira de como as pessoas usam a terra e os recursos naturais devem receber o apoio tantos dos que formulam as políticas quanto daqueles que serão afetados por elas. Os esforços no sentido do desenvolvimento sustentável devem propiciar benefícios para todas as partes - para os grupos atuais afetados, para gerações futuras e para o meio ambiente. O desenvolvimento sustentável deve ser mais atrativo e deve melhorar a qualidade de vida das pessoas, de maneira que seja uma escolha e não uma imposição.

O desenvolvimento de bases de apoio pode ajudar a gerar apoio político e restringir o uso não sustentável dos recursos florestais. Devem fazer parte destas bases de apoio não só as pessoas que vivem na floresta ou perto dela, e que retirem dela seu sustento 
através do desenvolvimento sustentável, mas também outros setores da sociedade, tais como a comunidade científica, grupos empresariais, meios de comunicação, governantes e residentes urbanos cientes da necessidade da conservação dos recursos naturais. Uma das tarefas do programa é construir estas bases, fazendo com que haja uma aceitação mais ampla do conceito de desenvolvimento sustentável e que haja uma participação mais ativa da sociedade civil.

O Programa Piloto representa um modelo novo de parceria internacional. A colaboração em questões ambientais de importância e preocupação mundial está sendo fortalecida através de novos arranjos e procedimentos institucionais em escala internacional. O governo brasileiro, o Banco Mundial e os doadores trabalham juntos para fazer com que esta parceria, que é inovadora, seja bem sucedida.

O setor privado, tanto no Brasil quanto no exterior, também deverá estar envolvido nas atividades do programa. O envolvimento da iniciativa privada é importante para que se abram mercados nacionais e mundiais para os produtos florestais e a adoção de práticas sustentáveis de manejo florestal e produção de madeira com origem certificada. Porém dificuldades como a incerteza sobre os mercados, a falta de informação sobre produtos e tecnologias, a titulação insegura da terra, e obstáculos legais e burocráticos detêm os investimentos do setor privado. O Programa deve remover estes obstáculos para aumentar o envolvimento do setor privado.

Nos últimos anos cada vez mais as pessoas entendem que o desenvolvimento não sustentável na Floresta Amazônica e na Mata Atlântica gera benefícios a curto prazo porém, em longo prazo, gera custos relacionados a destruição e degradação de ecossistemas complexos e perda irreparável da biodiversidade. A construção da capacidade de comunidades locais de desenvolver, adaptar e implementar formas sólidas de uso dos recursos é uma estratégia essencial para atingir o desenvolvimento sustentado da região. 


\subsection{3 - SNUC - Sistema Nacional Unidades de Conservação}

Áreas protegidas são áreas de terra e/ou mar especialmente dedicadas à proteção e manutenção da diversidade biológica e de seus recursos naturais e culturais. Através da co-gestão conduzida por governo e sociedade cível foi possível ampliar o número de Unidades de Conservação, um dos mecanismos importantes para a conservação da biodiversidade.

As Unidades de Conservação - UC são tipos especiais de áreas protegidas. São espaços territoriais (incluindo seus recursos ambientais e as águas jurisdicionais) com características regionais relevantes, legalmente instituídas pelo Poder Público, com objetivos de conservação e de limites definidos, sob regime especial de administração, às quais se aplicam garantias adequadas de proteção.

As UC podem ser de dois tipos: Unidades de Proteção Integral onde não são permitidas interferências humanas para fins de exploração e Unidades de Uso Sustentável que permite o uso sustentável de uma parcela de seus recursos naturais.

A área de extração do látex estudo desta dissertação está localizada em umas destas unidades, a Floresta Nacional Mapiá-Inauiní no estado do Amazonas.

A Florestas Nacionais, segundo definição de lei, são áreas com cobertura vegetal de espécies predominantemente nativas e tem como objetivo básico o uso múltiplo sustentável dos recursos florestais e a pesquisa científica, com ênfase em métodos para exploração sustentável de florestas nativas.

A FLONAé de posse e domínio públicos, sendo que as áreas particulares incluídas em seus limites devem ser desapropriadas. Nestas florestas é admitida a permanência de populações tradicionais que a habitavam quando da sua criação, em conformidade com o 


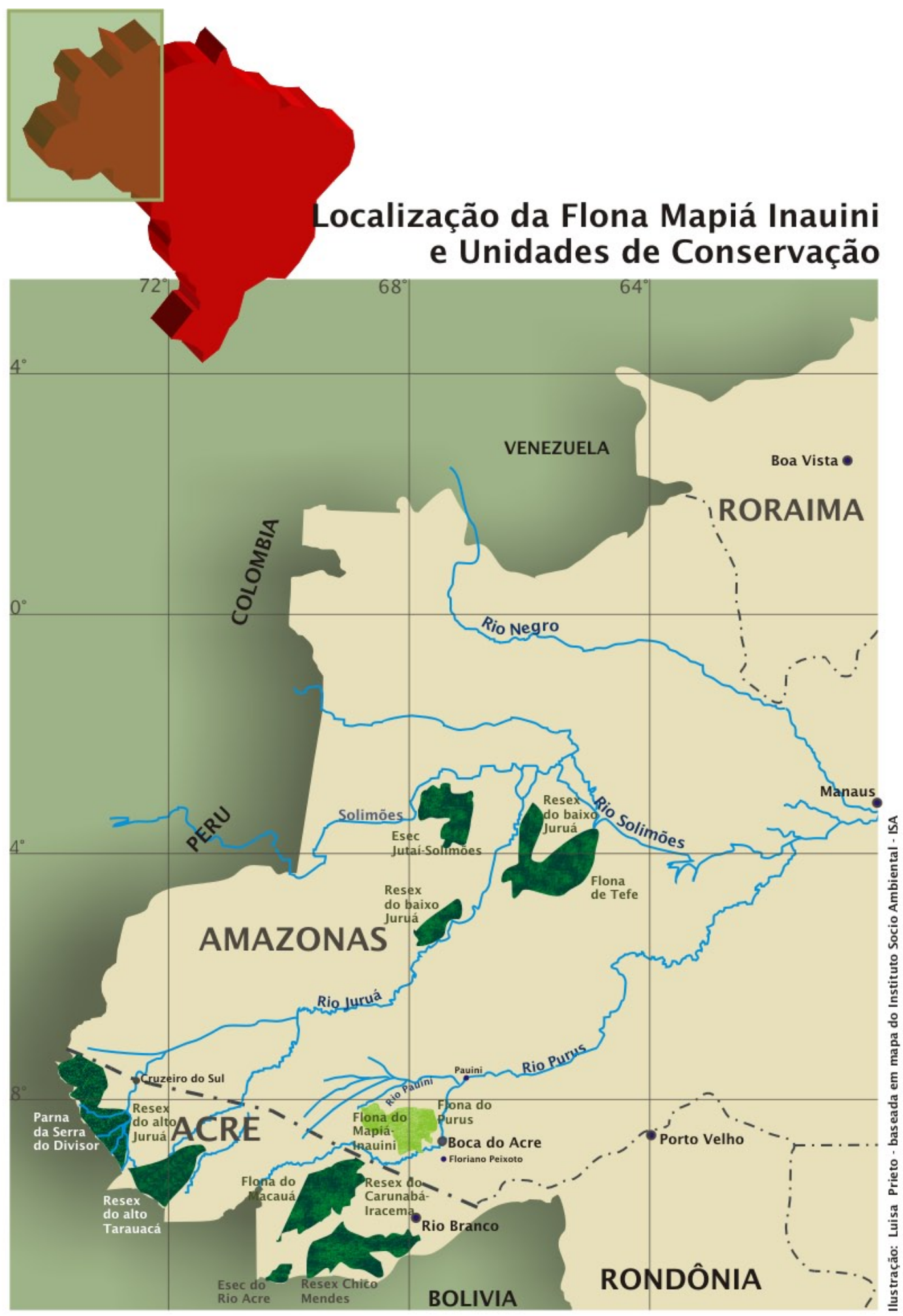

FLONA Floresta Nacional

PARNA Parque Nacional

RESEX Reserva Extraticista

ESEC Estação ecológica 
disposto em regulamento e no Plano de Manejo da unidade.

A visitação pública é permitida, considerada às normas estabelecidas para o manejo da unidade pelo órgão responsável pela sua administração. A pesquisa é permitida e incentivada, sujeitando-se à prévia autorização do órgão responsável pela administração da unidade, ás condições e restrições por estas estabelecidas e àquelas previstas em regulamento.

A FLONA tem um Conselho Consultivo, presidido pelo órgão responsável por sua administração e constituído por representantes de órgãos públicos, de organizações da sociedade civil e, quando for o caso das populações tradicionais residentes.

As outras UC que permitem a extração de matéria prima através do extrativismo são:

Reserva Extrativista - RESEX que são áreas utilizadas por populações extrativistas tradicionais, cuja subsistência baseia-se no extrativismo e, complementarmente na agricultura de subsistência e na criação de animais de pequeno porte, e tem como objetivos básicos proteger os meios de vida e a cultura dessas populações, e assegurar o uso sustentável dos recursos naturais da unidade. A exploração comercial de recursos madeireiros só será admitida em bases sustentáveis e em situações especiais e complementares às demais atividades na Reserva Extrativista.

Reserva de Desenvolvimento Sustentável - RDS que são áreas que abrigam populações tradicionais, cuja existência baseia-se em sistemas sustentáveis de exploração dos recursos naturais, desenvolvida ao longo de gerações e adaptadas às condições ecológicas locais e que desempenham um papel fundamental na proteção da natureza e na manutenção da diversidade biológica. A Reserva de Desenvolvimento Sustentável tem como objetivo básico preservar a natureza e, ao mesmo tempo, assegurar as condições e os meios necessários para a reprodução e a melhoria dos modos e da qualidade 
exploração dos recursos naturais das populações tradicionais, bem como valorizar, conservar e aperfeiçoar o conhecimento e as técnicas de manejo do ambiente desenvolvido por estas populações.

\subsection{Preservação das Florestas e Desenvolvimento na Amazônia}

O termo Amazônia pode se referir à diferentes áreas geográficas:

A Amazônia Clássica que corresponde a uma divisão política e geográfica formada por seis estados conhecida como Região Norte: Amazonas, Pará, Roraima, Rondônia, Acre e Amapá. A floresta tipo hiléia é predominante.

A Amazônia Legal que foi criada em 1996 pelo governo federal para juntar aos estados daAmazônia Clássica parte daqueles que situavam em suas bordas: Maranhão, Tocantins e Mato Grosso, tendo com ela uma certa identidade física humana e histórica seja no meio-norte, Nordeste, como no planalto central, Centro-Oeste. Desta maneira a região poderia receber incentivos fiscais, um fundo formado pela renúncia fiscal destinado a investimentos destinados a uma área pouco ocupada e conhecida.

O Bioma Amazônia que corresponde ao conjunto de ecossistemas que formam a bacia Amazônica. Está presente em nove países da América do sul. A hiléia amazônica possui grande concentração de árvores de grande porte, que atingem até 50 metros de altura. O Rio Amazonas é o eixo dominante por $300 \mathrm{~km}$. Considerando cada lado de seu curso, ocupa uma área de 3,5 milhões de $\mathrm{km}^{2}$.

A Bacia Amazônica que começa na sua nascente na Cordilheira dos Andes, no Peru, e vai até a foz, no Amazonas. Tem uma extensão de $6400 \mathrm{~km}$, superando o rio Nilo. É 
também o maior rio do planeta em vazão, com um volume que varia de 120 milhões á 200 milhões de litros de água por segundo, e também em agia doce corresponde a 20\% de todos os rios do planeta somados.

O Amazonas que é o maior estado em extensão do Brasil com 1,5 milhões de km², correspondente á $20 \%$ da superfície do país. Sua principal atividade econômica se situa na Zona Franca em Manaus. É o estado menos alterado da Amazônia e de baixa densidade demográfica e por este motivo preocupação da segurança nacional uma vez que possui extensas fronteiras sem a presença de brasileiros.

AAmazônia brasileira ocupa mais de metade do território nacional (58\%) cobrindo uma área de 5 milhões de $\mathrm{km}^{2}$, uma área equivalente á metade $\mathrm{d}$ área continental dos EUA, ou mais do que 25 países europeus juntos. 1/5 da água doce do mundo circula na bacia hidrográfica. AAmazônia é a maior região de floresta tropical que resta no mundo. Junto com a Mata Atlântica contém uma diversidade vegetal e animal que não é encontrada e nenhum outro local.

A Floresta Amazônica é um ecossistema auto-sustentável, ou seja, mantém seus próprios nutrientes num ciclo permanente. Ajuda a manter o clima local e a controlar o efeito estufa pelo armazenamento de carbono; protege as bacias hidrográficas e fornece matéria-prima para o artesanato e a indústria.

Apesar da característica mais importante da Amazônia ser a floresta, a região é formada por uma grande variedade de ecossistemas entre os quais: mata de terra firme, florestas inundadas, várzeas, igapós, campos abertos e cerrados.

ARegião Amazônica abriga mais de 10 milhões de pessoas. Estima-se que 1,5 milhões de pessoas vivam na floresta. São os povos da floresta, entre os quais povos indígenas, seringueiros, castanheiros, pescadores e pequenos agricultores que dependem da flo 
resta para seu sustento e que também contribuem para sua manutenção.

A devastação tem crescido e este patrimônio natural encontra-se ameaçado. $15 \%$ já foi destruído e da área original da Mata Atlântica restou somente 7\%.

Na década de 80 aumentou a preocupação da comunidade internacional com a rápida destruição das florestas tropicais doBrasil e surgiram vários projetos que buscam soluções para cessar, ou pelo menos reduzir o ritmo da destruição. A posição do estado brasileiro é de encarar as florestas não só como um recurso natural a ser protegido mas também como uma fonte de renda para as populações regionais.

"A transição de um padrão de desenvolvimento que se esgota - a economia de fronteira para outro que emerge - o desenvolvimento sustentável - envolve todo o território brasileiro" (MMA, 1995.p.18).

O desenvolvimento da Amazônia tornou-se uma questão complexa que abrange conflitos de interesse acerca do meio ambiente. Ao mesmo tempo que a conservação da biodiversidade tem enorme valor como garantia de qualidade de vida para as futuras gerações, seus recursos naturais são fonte e meio de sobrevivência para as populações nativas e, ainda, base essencial de recursos para outros segmentos produtivos.

O Programa Áreas Protegidas da Amazônia -ARPAé um programa do governo federal, coordenado pelo MMA com duração prevista de dez anos, para expandir, consolidar e manter uma parte do SNUC no Bioma Amazônia, protegendo pelo menos 50 milhões de hectares e promovendo o desenvolvimento sustentável da região. São executores do programa: o IBAMA, as Organizações Estaduais de Meio Ambiente-OEMAs, o Fundo para a Biodiversidade - FUNBIO. São doadores: Fundo para o Meio Ambiente Global - GEF -Banco Mundial; KfW - Banco Alemão de Cooperação; WWF - Brasil. São Parceiros em Cooperação Técnica: WWF-Brasil e GTZ. 
O Plano Amazônia Sustentável - PAS é uma iniciativa do Governo Federal em parceria com os estados da região Amazônica e tem como objetivo implementar um novo modelo de desenvolvimento na Amazônia Brasileira pautado na valorização de seu patrimônio natural e sócio-cultural. Os objetivos são: geração de emprego e renda, redução das desigualdades sociais, viabilização de atividades econômicas e inovadoras, com inserção de produtos em mercados regionais, nacionais e internacionais, bem como para uso sustentável dos recursos naturais com manutenção do equilíbrio ecológico.

O Departamento de Agroextrativismo e Desenvolvimento Sustentável da Secretária de Políticas para o Desenvolvimento Sustentável do MMA tem por objetivo promover a formulação e gestão pública, assim como a execução de ações e projetos voltados para o Desenvolvimento Sustentável de populações Tradicionais, Quilombolas, Indígenas e produtores familiares, por meio do uso de recursos naturais respeitando a especificidades sócio-culturais destas populações.

Segundo o governo do Estado do Amazonas é necessária uma ampla parceria da sociedade brasileira para atingir a sustentabilidade. É necessário aumentar o consumo de produtos florestais madeireiros e não madeireiros da Amazônia, valorizando especialmente os que possuem selo verde ou orgânico. Devem ser desenvolvidos mecanismos para o pagamento dos serviços ambientais das florestas, ao produtor rural, com redução de impostos, incentivo ao crédito mais barato, reconhecimento da propriedade intelectual dos povos indígenas e populações tradicionais. É necessário criar uma rede que inclua a universidades e instituições de pesquisa, empresários e investidores privados, e alianças intergovernamentais. 


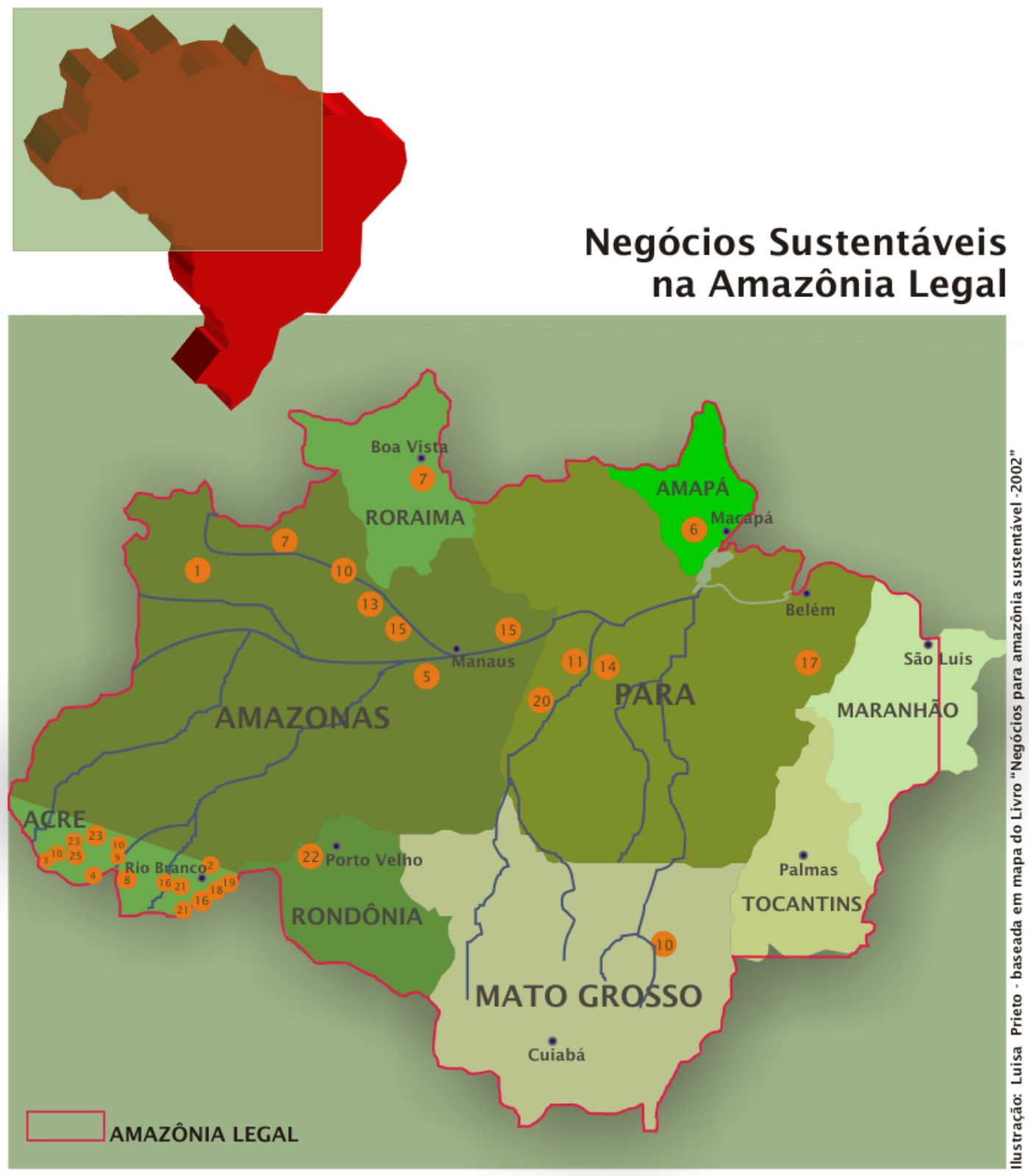

\section{Legenda}

arte e cestaria indígena

1 baniwa

2 apurinã

3 ashaninka

4 agentes agroflorestais indigenas

5 yakinõ

6 wajãpi

7 yanomani

8 publicações indígenas

9 kaxinawã

10 vídeo nas aldeias

artesanato de sementes e fibras naturais

11 curauá do lago grande

12 sementes pé de tucano

13 cestaria de novo airão

14 cestaria de santarém

madeira certificada e artefatos

15 oela

16 assentamento chico mendes

17 cikel

18 assentamento pedro peixoto

19 assentamento porto dias

20 oficinas caboclas do tapajós

21 aver amazônia

22 ecolog

novas alternativas para borracha nativa

23 couro vegetal da amazônia

24 pneu xapuri

25 tecbor

Figura 4: Negócios Sustentáveis na Amazônia 


\subsection{1 - Povos da Floresta}

As populações tradicionais da Amazônia são consideradas guardiãs da floresta, pois, com sua presença, conseguem conter o avanço da fronteira agrícola e de ações predatórias.

Segundo o Grupo de Trabalho Amazônico - GTA apoiar estas comunidades e projetos locais é a melhor estratégia de futuro para região. Fazem parte do grupo: agricultores, seringueiros, indígenas, quilombolas, quebradeiras de coco, pescadores, ribeirinhos e entidades ambientalistas, de assessoria técnica, de comunicação comunitária e de direitos humanos.

A cooperação com os povos nativos e tradicionais é essencial para encontrar o rumo da sustentabilidade e da cidadania que implica em mudanças também dos moradores das cidades através de seu consumo e de suas escolhas.

As comunidades extrativistas são aquelas que vivem basicamente da pesca, da caça, do plantio da mandioca e da coleta de produtos da floresta, como fibras, cipós, remédios, frutas, cascas, gomas e resinas. Conhecem profundamente a natureza e usam sem destruí-las, pois dependem dela para sobreviver.

As comunidades indígenas são formadas pelos primeiros habitantes conhecidos da Amazônia. Os índios detém o conhecimento ancestral da floresta e uma técnica de interatividade, que permite explorar o meio ambiente sem destruí-lo.

Existem 30.000 comunidades extrativistas que vivem em áreas rurais. Os índices sócioeconômicos destas áreas são muito baixos e se traduzem em baixa qualidade de vida e falta de oportunidade para a população. O custo de produção é alto, o que dificulta a agregação de valor, o escoamento dos produtos e consequentemente a rentabilidade 
econômica. Nos últimos 40 anos os problemas aumentaram com os desmatamentos (principalmente devido à queimadas e a conversão de terras para a agricultura), ocupação desordenada da terra, uso inadequado do solo e execução de grandes obras (estradas, barragens, usinas, etc.) sem que tenha havido cuidado para minimizar os impactos.

O extrativismo moderno, baseado na tecnologia e no manejo, permite agregar valor ao produto ainda na floresta, ou na margem do rio. Desta maneira é possível a comunidade local aumentar sua renda e colaborar para a manutenção do meio ambiente que melhora a qualidade de vida de toda sociedade. Pesquisas científicas comprovam que o uso racional dos produtos naturais resulta em aumento de produtividade e renda e garante a regeneração e conservação da natureza.

O Brasil se caracteriza por ter políticas ambientais que não estão somente baseada em iniciativas do governo, mas também dos diferentes segmentos da sociedade como as organizações não-governamentais, institutos de pesquisa e empresa privadas.

A ONG WWF-Brasil, que tem apoiado o Projeto Couro Vegetal da Amazônia, faz parte das entidades que defendem a adoção de uma agenda pró desenvolvimento sustentável e conservação da biodiversidade. Para isso, toma por base o conceito ecoregional, que leva em conta a grande diversidade de paisagens do bioma e o impacto que qualquer elemento físico ou biológico tem sobre os demais. O conceito é valorizar a vocação florestal da região, conservando e utilizando recursos naturais de forma racional e duradoura para beneficiar todos os seguimentos sociais da região amazônica. 


\subsubsection{Conhecimento Tradicional}

A densidade na Amazônia é baixa, 2 habitantes por km² e está concentrada, principalmente nos centros urbanos e ao longo dos rios. A riqueza cultural das diversas etnias indígenas e das várias correntes migratórias inclui o conhecimento tradicional sobre usos e formas de explorar os recursos da floresta sem esgotá-los nem destruir o habitat natural.

O conhecimento tradicional é o acumulado por uma cultura em gerações, em estreita relação com a natureza, incluindo sistemas de classificação, de zoneamento e de manejo. Em relação à ciência ocidental é mais qualitativo, holístico e inclusivo. Estas culturas entenderam, privilegiadamente, que a biodiversidade, tomada como conjunto dos recursos genéticos, espécies e ecossistemas, viabiliza a vida humana. (Apud Ribeiro, 2003, p.446).

O modo de vida das populações indígenas e tradicionais foi colocado na agenda pública interrnacional, com vários desdobramentos: definição de áreas ocupadas por estas populações com áreas de preservação permanente, com uso; aproveitamento econômico destas áreas; direitos destas populações à autodeterminação, tanto á terra e os recursos naturais como de acesso ao mercado quando o desejarem; direito de propriedade intelectual sobre o uso no mercado de conhecimentos desenvolvidos por suas tradições

Segundo Mauro Leonel os índios e extrativistas não se beneficiaram economicamente, historicamente, dos vários dos produtos desenvolvidos por sua cultura como no caso do ciclo da borracha em que os ganhos foram para os donos dos seringais e exportadores. Ao contrário as atividades extrativistas levaram os índio e seringueiros a servidão, como no caso do regime de barracão, cumulativamente endividados, sem direitos à terra, aos recursos e ao resultado de seu trabalho. Quando acontece a reintrodução dos produtos ex situs, ou o adensamento in situ sob controle de outros interesses, os detentores desses conhecimentos não são recompensados. 
Á primeira vista, a hipótese de aliar preservação, diferença cultural, mercado e desenvolvimento para populações é animadora. Algumas correntes de pensamento acreditam que seja possível combinar a vontade de algumas populações e sua contribuição à preservação, e articulá-la com o capital industrial trazendo lucro para ambas as partes.

Os chamados capitalistas verdes defendem que para salvar a floresta, é preciso convencer governos e empresas a criar mercado rentáveis para os produtos da floresta. Porém experiências tem mostrado que o conhecimento não volta de forma vantajosa para os tradicionais quando colocado sob o poder de interesses externos, industriais ou do agrobusiness devido a um maior controle do acesso à informação, tecnologia, ao capital e à escala de produção. Para evitar que isso ocorra existem propostas de criação de instituições próprias para controle do conhecimento com realização de acordos sobre royalties e negociação de autorizações e compensações.

A jurisprudência internacional reconhece a propriedade intelectual da criatividade e das inovações das empresas, pelas patentes, mas não a informal, tradicional, coletiva ou intergeneracional. Os recursos dos ecossistemas tropicais são considerados herança da humanidade, sem dono, livres para patente e comercialização. O conhecimento tradicional é considerado bem coletivo e a tecnologia, privado. A partir do processo de amostras coletadas, a "descoberta" é patenteada e os direitos passam para a empresa financiadora, protegidas como mercadoria.

Patentear produtos resultante do conhecimento tradicional sem reconhecer os direitos das populações é visto com restrições do ponto de vista ético por haver a apropriação do conhecimento sem que haja repartição de benefícios com as populações detentoras.

Por existir diferenças culturais, outros problemas devem ser considerados na comercialização dos produtos locais, pois, existe uma incompatibilidade da visão indígena com as exigências de produção e mercado que envolvem tecnologia, ritmo de trabalho, escala 
de produção, administração e financiamento além da forma de apresentação do produto no mercado, ou seja de design de embalagem do produto. 


\section{A BORRACHA NATURAL}

“... a minha esperança é que todos os nossos jovens, eles vão usufruir de todo esse trabalho e que, realmente, os jovens daqui para frente, eles vão ser os grandes beneficiados desse futuro da Amazônia. Uma Amazônia preservada e economicamente viável...Eu acredito que, na medida que as primeiras Reservas Extrativistas começarem a dar seus frutos, o governo vai ter que reconhecer a importância deste trabalho que nós pretendemos desenvolver. Para o nosso bem e para o bem da humanidade. Esse é o meu sonho." (Chico Mendes, 1988, Xapuri, Acre) $^{*}$

\section{1 - Borracha Natural: matéria prima renovável}

Os materiais são substâncias físicas usadas com "entradas" para produção ou manufatura. As matéria primas são os primeiros materiais extraídos da natureza que depois se transformam em "materiais semi-acabados".

A borracha natural é o produto primário da defumação do látex extraído da seringueira.

A seringueira é a principal fonte de borracha natural produzida no mundo.

O gênero Hevea pertence à família Euphorbiaceace e tem como ocorrência e dispersão natural a Amazônia Brasileira e países vizinhos próximos como A Bolívia, Colômbia, Peru, Venezuela, Equador, Suriname e Guiana. A classificação atual do gênero Hevea apresenta onze espécies, dentre as quais destaca-se Hevea brasiliensis com maior capacidade produtiva e variabilidade genética (Costa et al., 2001).

Sendo de origem vegetal é uma matéria prima renovável pois, se retirada numa velocidade que permite sua regeneração, estará sempre disponível na natureza para ser utilizada. Além disso permite sua extração sem que a árvore seja derrubada e por isso colabora para manutenção da "floresta em pé". 
de engenharia, que inclui também metais, fibras, concreto, madeira, plásticos, vidros dos quais depende parte da tecnologia moderna.

A borracha é o único produto natural que possui elasticidade, plasticidade, resistência ao desgaste, propriedade isolante de elasticidade, e impermeabilidade para líquidos e gases, sendo essencial como matéria prima na indústria e principalmente no setor de transportes. O plástico inteligente mais antigo que se conhece. Através do processo de vulcanização adquire a propriedade de voltar a sua forma original depois de ter sido deformada por um esforço mecânico, ou seja é um material com memória. Ao ser estimulada por um esforço mecânico, a borracha responde com uma contração de forma.

A borracha só se tornou uma matéria prima importante, quando em 1839, foi descoberto o processo de vulcanização atribuída a Charles Goodyear, nos Estado Unidos e a Thomas Hankok, na Inglaterra.

Através de enxofre e calor foi possível melhorar as condições químicas e físicas do material que então não mais amolecia com temperatura elevadas ou endurecia em temperatura fria. Com as propriedades elásticas mais duradouras suas aplicações multiplicaram-se.

\footnotetext{
"Na história da percepção dos recursos naturais, a borracha tem o seu lugar à parte. A borracha entrou no desenvolvimento do processo industrial a partir de meados do século passado, quando a tecnologia do ferro era onipresente e totalizante. A estrada de ferro foi o produto mais vigoroso e universal de uma época que antecedeu o uso da borracha. Esta não veio substituir quase nada, mas complementar quase tudo. A ferrovia marcou a época da roda de aço em contato direto com os trilhos de aço. Já a descoberta dos usos múltiplos da borracha - tornado possível intermediar o aço em relação ao chão - coloca o automóvel em todas as ruas, estradas e rodovias do mundo. Ao ferroviarismo acrescenta-se o flexível rodoviarismo, sob a intermediação do uso da borracha e dos óleos lubrificantes. (Ab’Sáber, apud Dean, 1989, p. 8).
} 


\title{
3.2. Extrativismo e Plantio
}

\begin{abstract}
A domesticação das plantas é uma das realizações mais conseqüentes da humanidade. O cultivo dos vegetais multiplicou os humanos, impulsionou a civilização e estabeleceu para melhor ou para pior, o domínio do homem sobre a natureza. ( Dean, 1989, p.21).
\end{abstract}

Desde os tempos de Colombo a prática de transferência de plantas domesticadas é realizada. Este fator foi de fundamental importância para suprir a demanda de alimentos da população crescente, para a ampliação do comércio mundial e para expansão do imperialismo europeu.

Ao a expandir a agricultura os europeu interferiram de maneira agressiva nas relações entre plantas, parasitas e pragas. Apesar de passarem desapercebidas estas mudanças eram também históricas inseparáveis das mudanças sócio políticas que sucederam à introdução de novos cultivares.

Por volta do século XIX , a transferência de plantas exóticas e a busca de plantas selvagens possíveis de domesticação eram atividades que se tornaram racionalizadas , organizadas e postas a serviço do capitalismo industrial. A Europa mandava coletores aos mais distantes rincões da terra à procura de espécies desconhecidas que pudessem servir de matéria prima, remédio ou ornamento.

De todos os feitos daquela época de descobertas científicas, nenhum foi mais grandioso que a domesticação das árvores produtoras de borracha...

A história da borracha brasileira, precisa começar com o mito, porque tal mito sobrevive, conquistou a imaginação do mundo inteiro e é poderosos e maligno. É o mito de Henry Wickham, o herói inglês o doador das sementes de seringueira. É o mito de Henry Wickham, o patife inglês, o ladrão das sementes de seringueira. (Dean, 1989, p.29). 
O centro deste debate está relacionado a transferência da seringueira para fora da

Amazônia brasileira, através de um carregamento de sementes feito por Wickmham para

o Jardim de Kew Gardens na Inglaterra e sua posterior domesticação no Sudeste Asiático

fato que foi visto por alguns pesquisadores brasileiros como um caso de roubo.

"Em 1912, houve a primeira crise da borracha. Naquela ocasião, pesquisadores Ingleses levaram mudas de hevea brasilienses para cultivar na Malásia. Foi o primeiro gesto de biopirataria de que se tem notícia na região.... É verdade que os barões da borracha esbanjavam riqueza, apoiados nos patrões, seringalistas que impunham aos seringueiros regime de trabalho semi-escravo. Ainda assim, o fato é que o Brasil foi vítima de um roubo. (Silva, Marina em Viana et al., 2001, p. 201).

As desvantagens essenciais do extrativimo em relação ao plantio da seringueira derivam da dispersão das árvores lactíferas dentro da estrutura florestal, como por exemplo, os altos custos produtivos, a baixa produção e produtividade e as longas jornadas de trabalho.

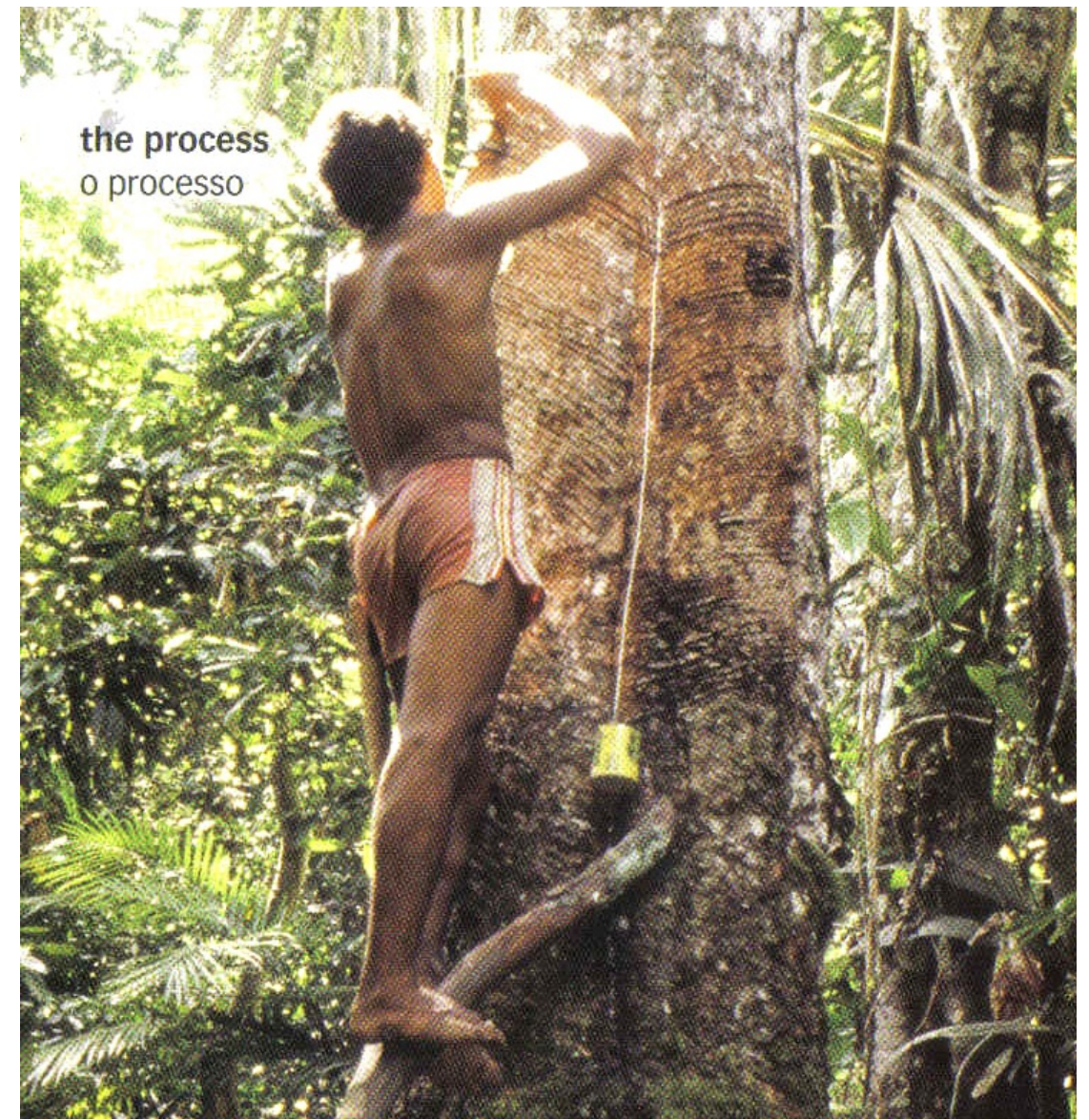

Figura 5: Fotografia da extração do látex da seringueira
"Oextrativismo daborracha da Amazônia foi gradativamente desativado a partir dos anos 80, mas ainda gera ocupação e renda para inúmeras comunidades de seringueiros. (Agenda de Trabalho, Câmara Setorial da Cadeia Produtiva da Borracha Natural, 2006, p. 6). Nas áreas mais úmidas da Amazônia e com maior incidência do mal de folhas, devem ser privilegiados os projetos voltados ao extrativismo sustentável, à agregação de valor à borracha voltado e sua colocação em nichos especiais de mercado na forma de artefatos fabricados por indústrias cuja instalação deve ser estimulada pelos governos dos estados e municípios da região, para absorver a produção e gerar renda as comunidades ribeirinhas evitando o transporte da borracha Amazônica até 
as indústrias localizadas nas regiões Leste e Sudeste do país. Esse projetos devem ser incentivados, pois além do seu benefício sócio econômico servem para continuar valorizando os nosso seringais nativos que são verdadeiros bancos de germoplasta in situ da espécie, de extrema importância para o futuro da heveicultura. (idem, p. 44)

A borracha dos seringais nativos representa relativamente pouco na produção nacional, porém, a questão do fornecimento de insumos produtivos e da manutenção da família do seringueiro, historicamente se constituiu no fator crítico que favoreceu o estabelecimento de uma cadeia de dominação e de exploração, onde o seringueiro foi o elo mais fraco e explorado.... Os insumos necessários para a produção de borracha dos seringais nativos depende da oferta de canecas, facas de sangria e pedras de amolar. Arma e munição para caça e proteção dos seringueiros que vivem isolados na floresta, lamparina e querosene para iluminação, e outros materiais de consumo como calçados, roupas e alimentos básicos para a família do seringueiro. (idem, p. 38)

\title{
3.3 - Ciclos da Borracha e Movimentos Socioambientais
}

\section{O primeiro ciclo da borracha na Amazônia ocorreu de 1870 a 1912. Começou quan-}

do, por causa da invenção da vulcanização pode ser usada em grande escala, e sendo proveniente da uma árvore nativa da região Amazônica o mundo dependia da produção brasileira. Para atender a demanda pela matéria prima ocorreu uma grande migração de mão de obra nordestina.

\begin{abstract}
"Preços altos até 1912 significaram importações maciças de nordestinos homens, e pouquíssimas mulheres, que ficavam na estrita dependência do barracão ${ }^{1}$ para obter seus víveres, já que eram proibidos de plantar para seu próprio sustento e de vender a comerciantes independentes, os regatõe ${ }^{2}$ Significaram também matanças de aldeias inteiras de índios, com exceção de mulheres jovens e algumas crianças, incorporadas à população seringueira; ou então a arregimentação de índios para trabalhar nos seringais ou para afugentar outros grupos indígenas." (Almeida, 2002, p.105)
\end{abstract}

Em 1913, a produção inglesa na Malásia superou a brasileira e em seguida muitos seringais foram abandonados no Brasil, encerrando desta maneira o primeiro ciclo da borracha.

Um novo ciclo, de 1943 a 1945, teve início quando o Japão invadiu o sudeste asiático e cortou o acesso dos aliados à borracha provenientes das colônias asiáticas inglesas,

\footnotetext{
${ }^{1}$ Barracão: Centro econômico-admistrativo do seringal, no qual se encontra a casa do patrão ou gerente do seringal. (idem)

${ }^{2}$ Regatão: AMAZ mercador que percorre os rios de barco, parando em vários povoados. (Houaiss, 2001, p.2415)
} 
holandesas e francesas. Em 1943 o Brasil uniu-se aos aliados e, como a borracha tinha importância estratégica, por suas aplicações militares, comprometeu-se a exportar toda sua produção para os Estados Unidos da América. Os preços dobraram, e o governo brasileiro que havia assumido o compromisso de levar para a floresta Amazônica 50 mil trabalhadores recrutou nas cidades e vilas do nordeste, mediante propaganda e promessa de benefícios, os migrantes ficaram conhecidos como "soldados da borracha".

A relação entre os patrões, chamados de seringalistas, e os migrantes seguia um contrato padrão. Aparentemente o contrato serviria para melhorar as condições trabalhistas para os seringueiros, mas o que ocorreu é que de certa forma piorou. O trabalhador só poderia se dedicar um dia da semana as atividades agrícolas, o resto da semana era dedicada ao corte da seringa. No pós-guerra toda borracha passou a ser monopólio do Estado sendo também o governo o órgão que aviava ${ }^{3}$ todos os patrões ou "seringalistas" os quais por sua vez também aviavam os seringueiros. Desta maneira toda borracha produzida era considerada pagamento de dívida e foi considerado crime vender borracha para os regatões.

Mais do que a quantidade produzida, o resultado mais importante da "Batalha da Borracha", foi o reconhecimento, pelo governo federal, dos interesses regionais dos patrões de seringais. A Constituição de 1947 determinou que 3\% do orçamento federal fosse para a Amazônia e o monopólio federal foi prorrogado. A proteção aos preços se estendeu até 1986 quando começou nova queda de preços e em 1996 foi determinado o final do protecionismo.

Na década de 80, os seringueiros começaram a se revoltar contra a situação de dependência simbolizada pelo pagamento anual da renda das estradas (caminhos usados para a extração de seringa) e contra a violência usada pelos patrões para garantir o monopólio comercial sobre a borracha. Iniciou-se então uma revolta dos seringueiros contra esta situação que era qualificada como sendo de cativeiro ou semi-escravidão.

${ }^{3}$ Aviador: Quem fornece aviamento, mercadoria que se recebe em troca de borracha. (Marchese, 2005, p.133). 
Com o apoio do Conselho Nacional dos Seringueiros, de líderes sindicais rurais, representantes da Igreja Católica e uma rede de assessores e aliados, conseguiu-se estabelecer uma visão e uma agenda em defesa de seus direitos.

A luta assumiu também características de uma luta ecológica pois foi criada uma resistência contra pecuaristas, madeireiros e exploradores de terra que aportaram pelas estradas para substituir antigos patrões e expulsar os seringueiro e derrubar a floresta. Ambientalistas, do Brasil e do mundo, reconheceram nos seringueiros, não um destruidor da floresta em busca de alimentos, mas um parceiro na preservação das florestas.

\begin{abstract}
"O movimento ambientalista...quando se associa às lutas sociais, transforma-se em ambientalismo político, definido como a ação dos movimentos sociais que defendem os recursos naturais por se constituírem a base produtiva a partir da qual obtém sua sobrevivência e buscam formas sustentáveis, do ponto de vista tecnológico social e institucional, de explorá-los. São movimentos que utilizam as vantagens comparativas derivadas da concentração em seu territórios, de recursos estratégicos como a biodiversidade, para negociação de modelos alternativos de desenvolvimento. (Alegretti, 2002, p.7350)
\end{abstract}

Os seringueiros organizaram-se contra o monopólio comercial dos barracões, o pagamento da renda em terras sem dono legítimo e a violência. Contemporaneamente os índios, sobreviventes de massacres, começaram a lutar por seus direitos territoriais. Os dois grupos, índios e seringueiros, anteriormente inimigos, começaram a se dar conta que possuíam interesses comuns, a favor da justiça social e da preservação da floresta, e o resultado foi a formação da "Aliança dos Povos da Floresta", algo inédito na história do Brasil.

"Agrande mudança, porém, foi a união esclarecida entre os povos da floresta: índios e seringueiros. Um acontecimento que comoveu o mundo esclarecido, ao fim de um século. Resta-nos a esperança de que as autoridades brasileiras - atuais e futura - entrem em consonância com as expectativas amazônidas e contribuam para uma ajuda substancial aos grupos humanos adaptados a conviver com a floresta. Não se trata de eliminar, por uma forma ou outra, os dignos herdeiros de uma geografia humana sofrida: mas sobretudo, de lhes dar um feixe de pequenas e indispensáveis infra-estruturas para que eles e seus filhos tenham a possibilidade de opção entre continuar sendo seringueiros ou seguirem outros caminhos no amplo espectro de espaços sócioeconômicos de uma Amazônia em mudança. (Ab'Sáber, em Dean, 1989, p. 9). 
No ano de 1985, em Brasília, foi realizado o Encontro Nacional dos Seringueiros. Neste momento começou a primeira articulação internacional dos seringueiros e o conseqüente reconhecimento internacional do movimento. A Comissão Brundtland responsável pela preparação da Rio 92 esteve no Brasil, e recebeu em audiência pública realizada em São Paulo os líderes do Conselho Nacional dos Seringueiros e da União da Nações Indígenas. Foi criado então um novo paradigma do movimento ambientalista em que direitos humanos deveriam ser considerados em conjunto com direitos ambientais. Naquele momento foi reconhecido que dentro da floresta moravam pessoas, que dependiam da floresta para a própria sobrevivência e por isso protegiam os recursos naturais e queriam ser reconhecidas como protetoras e guardiãs deste patrimônio.

Um dos resultados práticos de uma década de empates ${ }^{4}$ nas florestas, proposto pelo movimento acreano liderado por Chico Mendes foi a criação das Reservas Extrativistas - RESEX uma área onde os seringueiros poderiam diversificar a produção extrativista, garantir o uso da terra e da floresta e assegurar que cada família extraísse o látex em sua própria colocação $0^{5}$, com uma área média de 300 hectares. A proposta das reservas indígenas se integrava a um novo projeto de reforma agrária para a Amazônia, considerando a diversidade social, cultural e biológica dos diferentes ecossistemas. (Silva, Marina,2001,p.205)

Alguns fatos agravaram a situação de conflito entre latifundiários e as lideranças sindicais rurais. Chico Mendes era o líder mais conhecido e continuava a incentivar a lutas pelas RESEX. Por outro lado foi também protagonista de uma ação de grande impacto na políticas de empréstimos internacionais. Acompanhado pelo produtor americano de cinemaAdrian Cowell e pelo antropólogo Steve Schwartzman, membro de uma das ONGs norte-americanas mais importantes, a Environmental Defense Found, compareceu em 1987 à Reunião Anual do BID em Miami e informou aos doadores do Banco que se a estrada, BR 364 Porto Velho-Rio Branco, para qual estava destinado os recursos, continuasse a ser construída, sem que fossem tomadas medidas de proteção aos índios e seringueiros, poderia resultar em alto impacto social e ambiental para o Acre e Amazônia.

\footnotetext{
${ }^{4}$ Empate: no vocabulário amazônico empatar significa impedir. Pressionados pelos novos proprietários de terra, os seringueiros protagonizaram a reinvenção de resistência popular da floresta. $O$ empate às derrubadas foi uma iniciativa local que resultou da organização do primeiro sindicato de trabalhadores rurais no Acre, em Brasiléia, e da consciência sobre o direito de posse, assegurado pelo Estatuto da Terra. (Souza, 2007, p. 78)

${ }^{5}$ Colocação : unidade produtiva dentro do seringal, onde vive o seringueiro, onde ele constrói sua casa, tem suas "estradas de seringa", planta seus roçados, caça, pesca, retira a madeira e palha necessárias para a construção da casa, coleta frutos. Um seringal é formado por várias colocações. Por sua vez, cada colocação é formada por várias "estradas de seringa". (idem)
} 
(Alegretti, 2002 , p.741). Como conseqüência o desembolso de recursos foi suspenso pelo banco o que gerou indignação entre a elite acreana e os latifundiários começaram a agir com mais violência contra as lideranças sindicais. A partir de 1988 a tensão em Xapuri era grande e foi culminada com o assassinato de Chico Mendes em 1988, fato que ganhou grande repercussão internacional e uniu, durante a realização da Rio 92, várias ações em defesa da Amazônia.

Em 1995 os seringueiros passaram, através de Marina Silva, ela também nascida e criada nos seringais do Acre, a ter uma representante no Senado. Com João Alberto Capiberibe, eleito governador do Amapá e Jorge Viana, do Acre aparecia uma nova geração de políticos que buscou colocar em prática os preceitos do desenvolvimento sustentável.

Segundo Mary Alegretti, a defasagem ainda existente entre discurso e prática do desenvolvimento sustentável, se explica pela dificuldade de mudar a matriz de desenvolvimento baseado na inesgotabilidade para outra fundada na escassez e finitude dos recursos naturais pois implicaria em profundas transformações no modelo de desenvolvimento da humanidade.

Ainda hoje a borracha é a fonte principal de renda para os habitantes da floresta amazônica brasileira. Com o preço da borracha em baixa, os seringueiros estão perdendo capacidade de subsistência, o que gera êxodo rural e miséria urbana.

Uma das propostas de solução para estes problemas são os chamados negócios sustentáveis, que procura agregar valor a produção da borracha e aumentar e diversificar a oferta de produtos florestais não madeireiros como a castanha do Pará, frutas, óleos, plantas medicinais, artesanato de fibras e semente, etc. Para facilitar a comercialização dos produtos têm sido organizadas na região sudeste feiras e exposições como por exemplo: Mercado da Floresta, Feira Brasil Certificado, Amazônia BR e Negócios Sustentáveis da Amazônia. 


\section{O COURO VegetAL}

\subsection{O couro vegetal: aprimoramento do tecido encaucha- do}

O estudo de caso deste trabalho refere-se à produção de lâminas de couro vegetal pela APAS - Associação de Produtores de Artefato e Seringa de Boca do Acre, cidade localizada no estado do Amazonas e à confecção de produtos com utilização deste material pela Couro Vegetal da Amazônia e a comercialização pela empresa Amazon Life ambas localizadas no Rio de Janeiro.

O couro vegetal é o nome dado a um tecido formado a partir de duas matérias primas renováveis: o látex proveniente da seringueira (hevea brasiliensis) e o algodão. O látex proveniente da atividade extrativista e o algodão de cultivo.

O material é denominado "couro vegetal" pela sua semelhança visual com o couro de origem animal, porém não tem nada em comum em sua composição.

Esta denominação já havia sido mencionada em 1834:

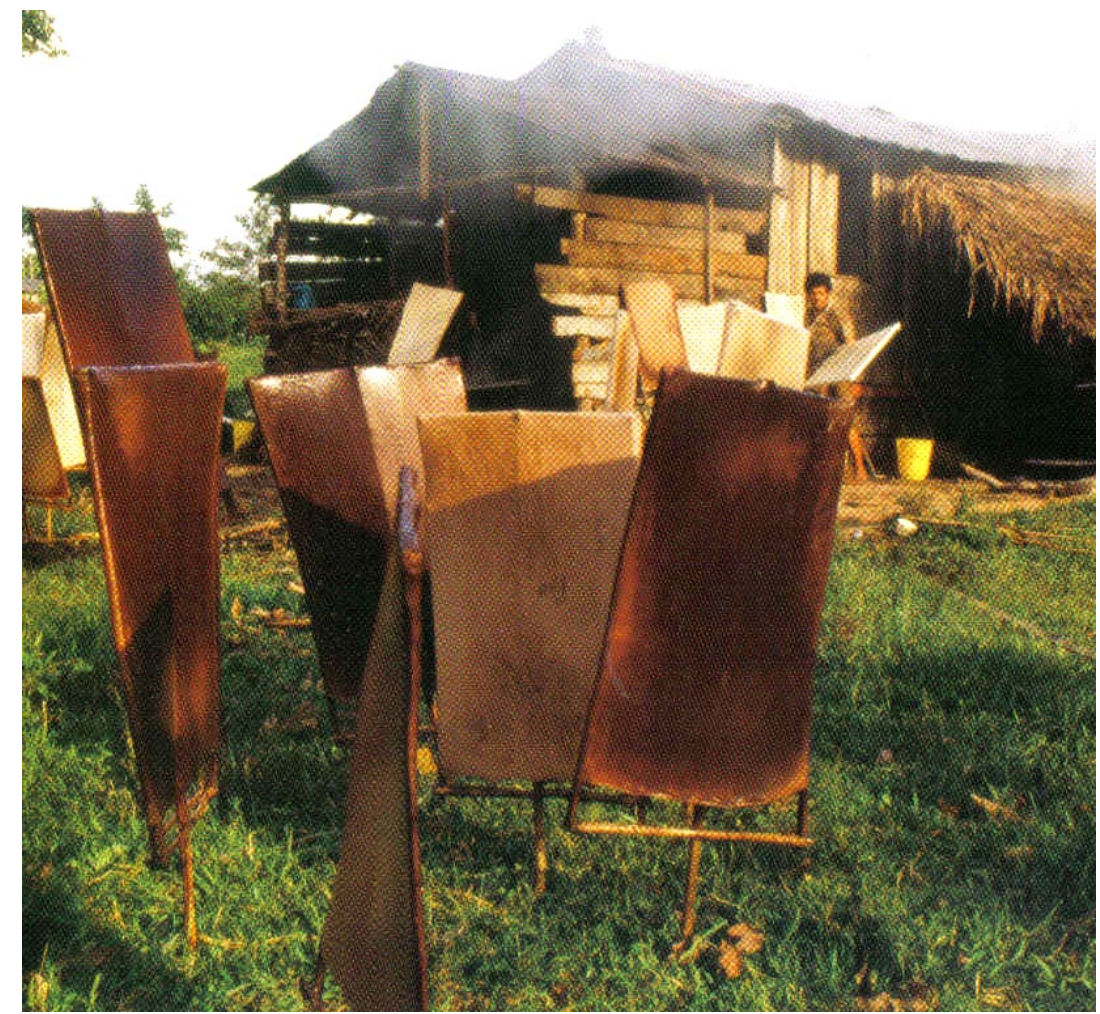

Figura 6: Fotografia de lâminas de couro vegetal secando ao ar livre após processo de vulcanização 
"Goodyear via a borracha como nós conhecemos hoje: o primeiro e mais versátil dos "plásticos modernos". Ele percebeu a borracha como um "couro vegetal" que desafiava os elementos, um "metal elástico", substituto da madeira, que poderia adquirir várias formas, através da utilização de moldes." (site Goodyear)

A origem do couro vegetal produzido pela Couro Vegetal da Amazônia vem do material que os seringueiros, aproveitando látex das seringueira , utilizavam para confeccionar artigos de uso próprio como a bolsa "capanga" os sapatos de seringa e o saco encauchado (saco de algodão banhado e impermeabilizado com látex). O aprimoramento deste processo, através da vulcanização, deu origem ao tecido atualmente utilizado pela empresa na confecção de bolsas.

Na definição da APAS o produto tem proveniência específica, a Floresta Amazônica, e produção é feita pela população tradicional dos seringueiros:

\footnotetext{
"O couro vegetal é um material à base de látex natural, extraído das seringueiras nativas da Floresta Amazônica e confeccionado pelo processo tradicional dos seringueiros em suas moradas na floresta."
}

Sendo assim estaria excluído desta definição o mesmo produto se confeccionado a partir do látex proveniente de seringais plantados que não utilizam na sua produção o processo tradicional de extração da seringa.

Porém, em dissertação de mestrado da ESALQ, cujo objetivo era o de

"avaliar os processos de produção do couro vegetal produzido com látex de diferentes
cultivares de seringueira, especificamente os processos de impregnação de tecidos com
látex e de vulcanização da borracha natural impregnada bem como definir uma metodo-
logia de avaliação de resistência à tração para este tipo de material" (Sérvolo, 2006, p.9)
o couro vegetal é definido como sendo um produto "obtido através do revestimento de
tecido de fibras celulósicas com látex de campo ou concentrado, extraído de seringueira"
(Hevea spp.).

Ou seja aqui o produto aparece desprovido das condicionantes regionais e de geração de renda, e passa a ser um produto destinado a atender possíveis demandas da indústria 
calçadista e da moda:

\begin{abstract}
" a possibilidade de obtenção de produtos com o couro vegetal sempre esbarrou na falta de padrão da matéria prima, sendo que esta variável é proibitiva para uma linha de produção em escala. Com este trabalho rompe-se esta barreira dando abertura a criação de inúmeros produtos beneficiados." (idem).
\end{abstract}

\title{
4.2 Projetos semelhantes ao Couro Vegetal da Amazônia
}

Existem projetos posteriores desenvolvidos em vários estados, que também utilizam o látex para produção de mantas e artefatos deste material. É importante citá-los para melhor entendimento do universo da produção do couro vegetal.

\section{DISTRITO FEDERAL Programa Tecbor}

Coordenação Latec - Laboratório de Tecnologia Química da Universidade de Brasília Tecnologia para produção de borracha e artefatos na Amazônia

Produto: FDL - Folha de Defumação Líquida

Semelhante ao produto couro vegetal existe o trabalho desenvolvido pela Universidade de Brasília através do projeto Tecbor, do Latec - Laboratório de Tecnologia Química, porém o produto não é exatamente o mesmo, pois não utiliza a manta de algodão: são lâminas confeccionadas exclusivamente com o látex. A fase piloto foi realizada de junho de 1997 à fevereiro de 1999.

O programa Tecbor - Tecnologia para produção de borracha e artefatos na Amazônia - consiste em uma proposta tecnológica alternativa para produção de borracha natural, que permite ao seringueiro preparar um produto beneficiado, empregando técnicas e 
materiais simples e de baixo custo. O coagulante é um ácido pirolenhosos obtido da carbonização da madeira. A lâmina de borracha, FDL - Folha de Defumação Líquida, após secagem ao ar livre, de poucos dias, é um produto de boa qualidade que pode ser direcionada para produção de artefatos especiais ou, em geral, para substituição da folha fumada. Esta tecnologia está direcionada para que o seringueiro trabalhe com a família, constituindo uma micro-usina de processamento do látex, agregando valor ao produto, evitando um processo intermediário na usina de beneficiamento. * (site UNB).

O objetivo é o aumento de renda que poderá proporcionar a condição que o seringueiro almeja de permanecer na floresta ao invés de migrar para a periferia das cidades em buscas de melhores condições de vida. Uma das conseqüências dessa situação é a maior probabilidade de conservação da floresta na área do seringueiro, com proteção dos recursos genéticos e da sua própria cultura. Em 2001 o projeto foi premiado com o Troféu de Excelência de Tecnologia Social da Fundação Banco do Brasil. A FBB criou um processo de franquia Social para disponibilizar estas tecnologias para sua mais ampla difusão na sociedade. É importante ressaltar este projeto pelas semelhanças com o projeto da Couro Vegetal da Amazônia, porém, tendo sido desenvolvido por uma universidade pública procura disseminar a informação tecnológica em benefício da sociedade. É interessante notar que a premiação refere-se à Tecnologia Social, termo que une dois conceitos tecnologia e bem estar social, e que indica um caminho de sustentabilidade.

\section{ACRE \\ Projeto D' Arvore}

Produto: sandália de couro vegetal e crepe claro de borracha.

Promoção: Ecoamazon - Instituto de Econegócios da Amazônia e Capeb - Central de Associações de Pequenos Produtores Rurais e Extrativistas de Epitaciolândia e Basiléia.

Local de Extração: Epicolândia e Basiléia.

Local de Produção: Acre

Financiamento: ONG WWF. 
Colaboração Tecnológica: Couro Vegetal da Amazônia.

O objetivo do projeto é o desenvolvimento de produtos que utilizem matéria-prima da floresta Amazônica com objetivo de contribuir para a melhoria das condições sociais e econômicas da região amazônica.

A sandália utiliza duas matérias-primas provenientes da seringueira. O crepe é usado no solado e o couro vegetal nas tiras da sandália. Quando necessário as tiras são reforçadas com couro animal ou lona. Em baixo da palminha é colocado um preenchimento de cortiça para diminuir o peso da borracha.

O solado de crepe e o couro vegetal das sandálias são produzidos pela Capeb (28 associações das reservas extrativistas do Acre) e pelos índios kaxinawá. As sandálias são confeccionadas no Rio Grande do Sul.

O coordenar do projeto, João Tezza, explica que ao consumir o produto o consumidor participa da preservação da Amazônia. Em 2002 o projeto recebeu o Prêmio Iniciativa Social Inovadora do Banco Mundial.

\section{ACRE \\ Projeto Amazônia Vegetal}

Produtos: bolsas, casacos, bonés, estojos.

Local de Extração: RESEX Chico Mendes e Cazumbá-Iracema.

Local de Produção do Produto: Acre

Parceira: Ibama 
Para evitar a defumação, que é uma atividade nociva à saúde dos seringueiros pela emissão de fumaça pirolenhosa, a empresa em parceria com o lbama, desenvolveu uma tecnologia em que ao invés de queimar o látex para produzir a manta, os seringueiros usam a técnica de pintar o tecido com a matéria prima.

O proprietário da empresa, Solidei Lima, afirma que o couro é ecológico pois a fumaça não afeta a saúde dos seringueiros. Além disso foi desenvolvida uma técnica que permite a pigmentação do látex fazendo com que o material possa ser produzido em várias cores.

Para o empresário o seringueiros são valorizados e não é preciso que saiam das reserva para crescer profissionalmente. O litro do látex era vendido à $R \$ 1,60$ e hoje com um litro produzem uma manta que é vendida á $R \$ 16,00$ (7/12/2003).

As comunidades, num total de trinta famílias, são capacitadas pela empresa.

Na atividade de produção das mantas e 9 empregados dão conta de todo o processo produtivo, desde a criação do molde até o acabamento dos produtos. A empresa é totalmente acreana. Possui 11 máquinas industriais próprias com produção de 50 produtos por dia. O estoque conta com mil bolsas para ser lançado no mercado.

Os preços dos produtos variam de $\mathrm{R} \$ 33,00$ à $\mathrm{R} \$ 205,00$ de acordo com acabamento, padrão e textura do couro. (7/11/2003). 


\section{PARÁ \\ Projeto Couro Ecológico}

Produtores: ASMIPRUT-Associação Intercomunitária de Mini e Pequenos Produtores Rurais da Margem Direita do Rio Tapajós de Piquiatuba a Revolva

Produtos: bolsas, malas, mochilas e brinquedos

Local de Extração: FLONA do Tapajós

Local de Produção: Belterra de Maguary, Pará.

Apoio: MMA-IBAMA (Projeto Manejo Florestal Sustentável da Amazônia), USAID, PNUD

Data de início: 1995

Localizada a 726,3 km de Belém, o município de Belterra de Magary é povoado por 56 famílias seringueiras. 26 destas famílias participam da iniciativa do Couro Ecológico.

Em 2001 com o financiamento da USAID - Agência Norte-Americana para o Desenvolvimento Internacional houve uma melhoria em infra-estruutura do local e foi realizada um plano de negócios. Em 2004 a iniciativa recebeu o apoio do Promanejo - Programa de Apoio ao Manejo Floresta na Amazônia do Ibama com apoio do PNUD -Programa das Nações Unidas para o Desenvolvimento. Com isto foi possível aperfeiçoar a técnicas de produção do couro ecológico, o design dos produtos e ampliar os mercados de venda.

"A atividade é uma forma de manter o seringueiro no campo. Há alguns anos quando a borracha sofreu uma queda no preço, $70 \%$ dos seringueiros que viviam na floresta tiveram que ir para a cidade porque não tinham como sobreviver do látex" diz o diretor de vendas do projeto, Arimar Feitosa Rodrigues. "O projeto melhorou muito a qualidade de vida das famílias envolvidas. Antes a única fonte de renda era a agricultura familiar. Os ribeirinhos da comunidade de Maguary trabalham na produção de farinha de mandioca, feijão e arroz para sua subsistência. A produção do couro ecológico envolve mulheres e homens, melhorando assim as relações de gênero, além de resgatar os saberes e a cultura local e fomentar a organização comunitária". 
Arimar explica:

uma família que sobrevive apenas dos produtos que planta tem uma renda de $R \$ 150,00$ por mês, incluindo a ajuda dos programas de transferência de renda com o Bolsa Família. No couro ecológico é possível ganhar de $R \$ 250,00$ à $R \$ 600,00$. Os benefícios se estendem a todas as famílias da comunidade pois $5 \%$ do lucro da venda é repassado para um fundo comunitário destinado a ajudar a população, como por exemplo a comprar remédios.

O projeto recebeu menção honrosa no Prêmio ODM Brasil, destinado a contemplar práticas de trabalho em prol dos Objetivos de Desenvolvimento do Milênio - uma série de metas socioeconômicas que os países da ONU se comprometeram a atingir até 2015. O projeto foi apresentado na Semana Nacional pela Cidadania e Solidariedade como um modelo para ajudar o Brasil a cumprir metas da ONU.

Os produtos foram expostos em Bolonha, Itália num encontro de cooperativas. Segundo Arimar a cooperativas seguem os princípios do comércio justo e não superfaturam os produtos. Na França, com padrões de comércio normal uma bolsa de $R \$ 15,00$ é vendida á $\mathrm{R} \$ 124,00$ (45 euros) encarecendo muito o produto.

\section{AMAZONAS}

\section{Projeto Seringueira - Microempresa de confecção e comercialização} de bolsas e mochilas de couro vegetal.

Sócio: Wilson Manzoni

Local de extração: Flona Mapiá Inauiní

Local da empresa: Boca do Acre

Ano da Fundação: 1999

O artesão paulista, Wilson Manzoni, viajou para Rio Branco em 1978 e lá conheceu o padrinho Sebastião de Mota de Melo, seringueiro e líder comunitário. Sebastião ensinou 
a ele o processo de produção de artefatos de borracha. Numa iniciativa pioneira iniciou então a comercialização de produtos, que antes era de uso exclusivo do seringueiro, como bolsas e sapatos, em lojas de artesanato.

Em 1999 abriu sua própria empresa, a Seringueira, produz bolsa e mochilas de couro vegetal. Os produtos são confeccionados por costureiras locais e vendidos em Boca do Acre e nas cidades próximas, além da internet.

A parceria com a Couro Vegetal da Amazônia se deu quando era presidente da APAS, um vez que a associação é fornecedora das mantas de couro vegetal.

\subsection{A APAS - Associação de Produtores de Artesanato e Seringa da Boca do Acre - Amazonas/ Flona Mapiá Inauiní}

AAPAS foi fundada em 1995 e desde então trabalha produção do couro vegetal a partir de unidades de produção descentralizadas. É uma associação civil, legalmente registrada que tem como meta colaborar para a permanência do povo na floresta e incentivar a melhoria das condições de saúde e educação. Este trabalho beneficia atualmente 500 pessoas, sendo $89 \%$ seringueiros e seus familiares.

A área de atuação da APAS vai do Rio Acre (município de Boca do Acre, Amazonas) sobe e desce o Rio Purus até o município de Pauíni e percorre vários igarapés afluentes destes rios.

AAPAS tem como objetivo de colaborar na manutenção dos seringueiros na floresta tornando o beneficiamento do látex uma atividade mais rentável. Na produção de uma lâmina que utiliza 1,3 I de látex o seringueiro recebe $R \$ 3,00$. Na produção tradicional 
recebe $R \$ 1,5$ por kg de borracha para qual emprega 3,3 I de látex.

O bioextrativismo não agride o meio ambiente, trabalha com o conceito de "floresta em pé, que pressupõe a preservação da flora regional, e está representando uma alternativa de renda á comunidade local para a decadência que sofreu a produção da borracha.

Esta modalidade extrativista é vinculada ao tipo de organização social e ao universo cultural específico da região. A atividade não faz apenas o uso imediato (coleta de recursos animais ou vegetais), mas também usos mediatos (cultivo e beneficiamento de produtos) da biota, por meio da produção familiar ou comunitária e dentro dos valores e crenças das sociedades que habitam os ecossistemas da região.

As pessoas envolvidas na produção recebem treinamento em técnicas de produção, capacitação gerencial e administrativa, controle de qualidade e manejo florestal de produção. Aempresa Couro Vegetal da Amazônia leva os insumos (tecido de algodão e mistura química para a vulcanização). A população localé responsável pela produção das lâminas, pelo gerenciamento do processo produtivo, por parte do controle de qualidade e pelo envio do material até rio Branco, capital do Acre.

A produção do couro vegetal é um trabalho familiar realizado por unidades domésticas, sendo que cada unidade envolve de seis a dez famílias. A atividade dos produtores é realizada em duas fases. Primeiro recolhe-se o látex nos seringais das florestas (através das estradas de borrachas), e uma vez feita a extração, o material é levado para o terreno de suas casas (colocação). Neste terreno, existem dois espaços necessários para obtenção do couro vegetal: o defumador, onde o látex é aplicado ao algodão e defumado; e uma estufa, onde as mantas são vulcanizadas a altas temperaturas, usando-se lenha como combustível. Após essa última etapa, a manta ganha consistência e o couro vegetal está produzido. 
A produção familiar é vendida à empresa Couro Vegetal da Amazônia, que tem exclusividade na obtenção do material. O fato da renda obtida através da produção do couro vegetal levou á uma melhoria sensível na qualidade de vida das pessoas envolvidas no processo. Neste sistema eles recebem dinheiro em mãos, além de poder usufruir de uma espécie de cooperativa de consumo da cesta básica, que não existia antes.

Para Floriano Pastore Jr., professor da Unb, a renda maior, obtida na extração da borracha, diminui a migração do trabalhador para a cidades. Ele deixa de extrair madeira , evitar partir para a produção agropecuária precária e não fica a mercê do narcotráfico, que constantemente tenta recrutar pessoas daquela região para suas atividades.

\subsubsection{A Certificação FSC - Forest Stewardship Council}

A certificação tem o objetivo de garantir que o uso de recursos naturais é feito de maneira adequada, e apresenta uma alternativa à exploração predatória das florestas. Atesta que uma empresa ou comunidade obtém produtos florestais respeitando os aspectos ambientais, sociais e econômicos de determinada região.

A atuação do empreendimento pode estar sendo feita de maneira correta, porém a certificação é a garantia para o consumidor de que o produto é proveniente de uma floresta manejada adequadamente, que gera emprego e renda, que os direitos trabalhistas são respeitados e que ,ao mesmo tempo, respeita o meio ambiente. Desta maneira o consumidor sabe que sua compra contribui para a conservação das florestas.

A certificação florestal de maior reconhecimento e credibilidade é a do FSC - Forest Stewardship Council, traduzida para o português como Conselho de Manejo Florestal, uma organização não governamental internacional que tem como missão promover o bom manejo das florestas do mundo. 
Para a obtenção do selo FSC, um empreendimento deve estar de acordo com uma série de critérios sociais, ambientais e econômicas, também chamados de padrões. Uma equipe de avaliação independente utiliza essas regras ou padrões para verificar se o manejo da floresta está sendo bem feito e se os produtos desta floresta, madeireiros ou não, podem levar o selo FSC.

A certificação não é um processo simples, principalmente para atividades informais, pois exige controle de todas as etapas envolvidas no processo: desde as árvores utilizadas no extrativismo ou na derrubada no caso de extração de madeira, ao controle de estoque, à normas de segurança no trabalho. Cada árvore é numerada na floresta através do plaqueamento. Ou seja, a área florestal é toda mapeada. E todos processos de devem estar dentro da leis vigente no país: sejam leis trabalhistas ou de direito de posse da terra.

A certificação é um processo voluntário no qual a certificadora, uma organização independente credenciada pelo FSC, verifica o cumprimento dos Princípios e Critérios do FSC.

Os 10 princípios e critérios da certificação são:

\section{1 - Obediência às Leis e aos Princípios do FSC}

O manejo deve respeitar todas a leis aplicáveis ao país onde opera, os tratados internacionais e acordo assinados por este país, e obedecer os Princípios e Critérios do FSC.

\section{2 - Responsabilidade e direitos de posse e uso da terra}

Os direitos de posse e uso de longo prazo relativos à terra a aos recursos florestais devem ser claramente definidos, documentados e legalmente estabelecidos.

\section{3 - Direitos dos povos indígenas}


Os direitos e costumários dos povos indígenas de possuir, usar e manejar suas terras, territórios e recursos devem ser reconhecidos e respeitados.

\section{4 - Relações comunitárias e direitos dos trabalhadores}

As atividades de manejo florestal devem manter ou ampliar o bem estar econômico e social de longo prazo dos trabalhadores florestais e das comunidades locais.

\section{5 - Benefícios da floresta}

As operações de manejo florestal devem incentivar o uso eficiente dos múltiplos produtos da floresta para assegurar a viabilidade econômica e uma grande de benefícios ambientais e sociais.

\section{6 - Impacto ambiental}

O manejo florestal deve conservar a diversidade ecológica e seu valores associados, os recursos hídricos, os solos e os ecossistemas e paisagens frágeis e singulares, e ao assim atuar, manter as funções ecológicas e a integridade da floresta.

\section{7 - Plano de manejo}

Um plano de manejo - apropriado à escala e intensidades operações propostas - deve ser escrito, implementado e atualizado. Os objetivos de longo prazo do manejo florestal e os meios para atingi-los devem ser claramente definidos.

\section{8 - Monitoramento e avaliação}

O monitoramento deve ser conduzido - apropriado á escala e á intensidade do manejo florestal - para que sejam avaliados á condição da floresta, o rendimento dos produtos florestais, a cadeia de custódia, as atividades de manejo e seus impacto ambientais e sociais. 


\section{9 - Manutenção de florestas de alto valor de conservação}

As atividades em manejo de florestas de alto valor de conservação devem manter ou ampliar os atributos que definem estas florestas. Decisões relacionadas à florestas de alto valor de conservação devem sempre ser consideradas no contexto de uma abordagem precautória.

\section{0 - Plantações}

As plantações devem ser planejadas e manejadas deacordo comos Princípiose Critérios de 1 a 9 e o Princípio 10 e seus Critérios. Considerando que as plantações podem proporcionar um leque de benefícios sociais e econômicos e contribuir para satisfazer as necessidades globais por produtos florestais, recomenda-se que elas complementem o manejo, reduzam as pressões, e promovam a restauração e conservação das florestas naturais.

O processo de certificação deve incluir as seguintes etapas:

- Contato inicial - a operação florestal entra em contato com a certificadora;

- Avaliação - consiste em uma análise geral do manejo, da documentação e da avaliação de campo. Seu objetivo é preparar a operação para receber a certificação. Nessa fase são realizadas a consultas públicas, quando os grupos de interesse podem se manifestar;

- Adequação - após a avaliação, a operação florestal deve adequar as não conformidades (quando houver);

- Certificação da operação - a operação florestal recebe a cerificação. Essa etapa, a certificadora elabora e disponibiliza um resumo público;

-Monitoramento anual - após a certificação é realizado pelo menos um monitoramento da operação ao ano. (site FSC 23/12/2006).

O processo de certificação é conduzido pela certificadora. Cabe à ela avaliar opera- 
de manejo florestal ou de cadeia de custódia e de auditar operações certificadas. A cadeia de custódia permite que o produto final leve o selo FSC. A certificadora cobra pelos serviços prestados. Atualmente no Brasil existem cinco certificadoras credenciadas pelo FSC.

Para obter a certificação FSC, os empreendimentos florestais devem ter um plano de manejo que inclua, no mínimo, os seguintes aspectos:

- os objetivos do manejo;

- descrição dos recursos florestais a serem manejados, das limitações ambientais, do uso da terra, da situação fundiária e das condições sócio econômicas da unidade de manejo e entorno;

- descrição do sistema de manejo, baseado nas características ecológicas da floresta em questão e informações coletadas através de inventários florestais;

- planos operacionais anuais especificando todas as operações a serem realizadas na unidade de manejo florestal, incluindo critérios de seleção de corte, volume de corte anual, procedimentos para monitoramento do crescimento e da dinâmica da floresta - cujos resultados devem ser utilizados na justificativa para ciclo de corte;

- justificativa das técnicas de colheita escolhidas e equipamentos a serem utilizados;

- medidas para atenuação dos impactos ambientais identificados, incluindo a identificação e proteção de espécies raras, ameaçadas ou em perigo de extinção;

- mapas ou croquis descrevendo a base dos recursos florestais, incluindo áreas protegidas, principais tipologias florestais, topografia, hidrografia, infra-estrutura preexistente, usos atuais do solo e além das áreas vizinhas;

O plano de manejo incorpora a estratégia de longo prazo de abastecimento das unidades industriais, caso existentes, e os mecanismos de sustentabilidade econômica durante todo o ciclo previsto de recuperação da floresta ( em geral de 20 a 30 anos). (Brasil Certificado - Imaflora, 2005 )

No Brasil, o Imaflora - Instituto de Manejo e Certificação Florestal e Agrícola é a única 
entidade que certifica, além de empresas, comunidades rurais, através de manejo florestal comunitário.

Para ambientalistas do WWF é importante que a certificação da floresta não fique restrita somente à madeira, mas à todos os recursos da floresta como por exemplo a copaíba e a jarina. O apoio à esses projetos se dá através de Grupos de Produtores Florestais Comunitários.

O manejo florestal madeireiro não é algo tradicional das comunidades e povos da floresta, por isso há necessidade de capacitação e investimento. O manejo florestal não madeireiro por ser um sistema que se aproxima do universo do extrativismo é melhor assimilado pelas comunidades: faz parte da cultura do seringueiro colher a castanha, furar a copaíba, colher a casca do ipê para remédio, etc.

Para Luis Meneses, Coordenador do Programa Amazônia da WWF Brasil, a grande vantagem do Grupo de Produtores Florestais Comunitários e do qual o CTAé o assessor técnico, organizacional e político, é reunir a pequena oferta dos diversos grupos comunitários para negociar em quantidades significativas com grandes empresas e compradores no mercado. A venda coletiva é um grande avanço. O WWF busca processos de inclusão social trazendo o povo que está nas florestas para a economia de mercado. O trabalho tem sido direcionado para assistência técnica do manejo florestal e para o fortalecimento das capacidades administrativas, de liderança e participativas nas associações.

A expectativa é que em determinado momento as comunidades possam estar capacitadas para gerir seu próprio negócio. A WWF é parceira do projeto Couro Vegetal da Amazônia.

Uma das vantagens para as comunidades e populações locais é a possibilidade de entrar em contato com alternativas, economicamente viáveis, às práticas destrutivas da 
e de poder influenciar na conservação das áreas necessárias para a sua sobrevivência. Além disso, têm seus direitos preservados e acesso à novas perspectivas de renda.

\subsubsection{A Certificação FSC da APAS pelo Imaflora}

Para avaliação da APAS foi considerada a versão adaptada dos Padrões do FSC para Manejo Florestal em Terra Firme na Amazônia Brasileira (2002) e os Padrões Genéricos do SmartWood para Manejo do produtos Florestais Não madeireiros

No início de 2005 foi realizada auditoria na área de manejo florestal da APAS pelo engenheiro florestal da Imaflora, André Giacini Freitas com objetivo de:

- avaliar o plano de manejo aplicado às áreas florestais sob responsabilidade da APAS.

- avaliar a conformidade da operação florestal com os Princípios e Critérios do FSC, através das "Diretrizes Gerais SmartWood para Avaliação do Manejo Florestal”, versão de 2000, para que esta operação florestal pudesse ser fornecedora de matéria prima certificada.

- identificar as possíveis Pré-condições e Condições para que o Manejo Florestal da APAS seja certificado.

O resultado desta auditoria está presente no Resumo Público de Certificação FSC Programa SmartWood daAssociação dos Produtores de Artesanato e Seringa-APAS em Boca do Acre, Amazonas. Certificado número: SW-FM/COC-NTFP1447 de 10/03/2005.

A Rede Smartwood é coordenada pela Rainforest Alliance, uma ONG conservacionista internacional da qual o Imaflora é membro institucional. 
As áreas de manejo da APAS foram consideradas do tipo SLIMF - Small and Low Intensity Managed Forests por se tratar de um manejo florestal de pequena escala e baixa intensidade.

É um tipo de manejo comunitário para produção do látex de seringueira (Hevea sp. ) em propriedades rurais daAmazônia úmida brasileira, com extração de pequenos volumes de madeira para o processo de defumação e para lenha nas estufas. O manejo é organizado por uma associação comunitária e seus associados que realizam o processamento pri-

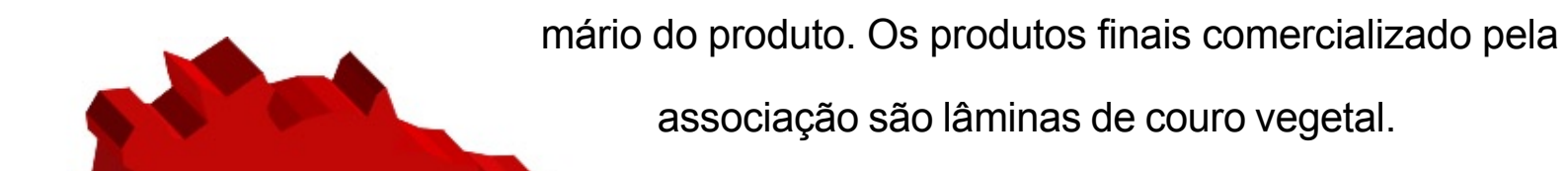

Unidades de Produção de Couro Vegetal da APAS

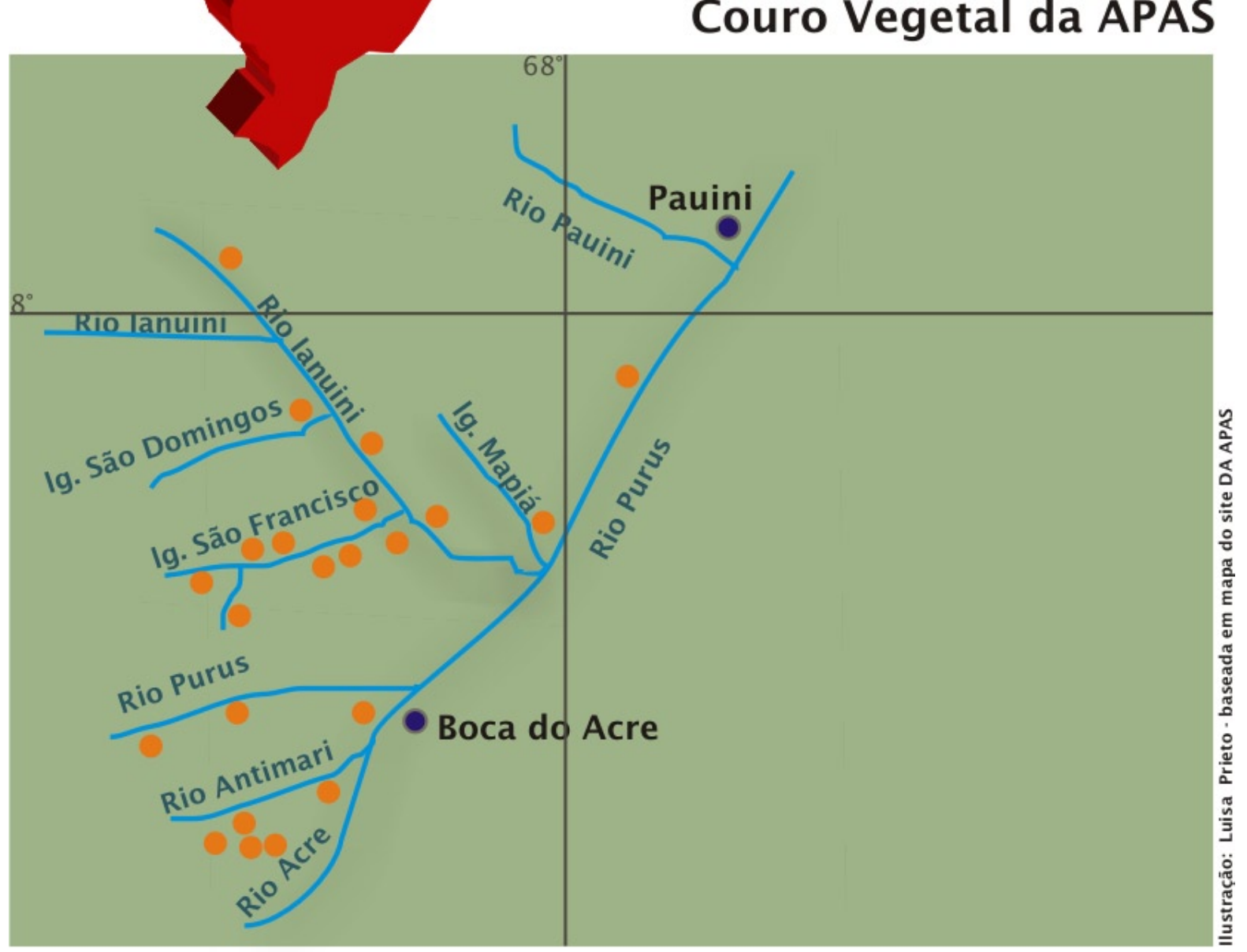

Ilnidadec de Producão de Courn Vecetal da APAS 
O manejo florestal conta com o apoio do Instituto Nawa, da empresa Couro Vegetal da Amazônia, do WWF - Fundo Mundial para a Natureza e Fundação Ford, além das parcerias técnicas com a Secretaria de Extrativismo e Produção Familiar do Estado do Acre, Laboratório de Produtos Florestais do Parque Zoobotâncio/Universidade Federal do Acre e do IBAMA.

As áreas de manejo estão localizadas ao longo do Igarapé São Francisco, dentro da Floresta Nacional Mapiá Inauiní e no seu entorno.

Localização da Flona Mapiá Inauiní:

Latitude: $07^{\circ} 57^{\prime} 39^{\prime \prime}$ a $08^{\circ} 41^{\prime} 54^{\prime} \mathrm{S}$

Longitude: $67^{\circ} 42^{\prime} 02^{\prime \prime}$ a $68^{\circ} 38^{\prime} 50^{\prime \prime} \mathrm{W}$

No manejo florestal estão envolvidas seis colocações que realizam a extração do látex. Quatro delas possuem unidades de produção de couro vegetal e extraem madeira para defumação das lâminas.

São realizados dois tipos de manejo: para do látex e para produção de madeira.

\section{Produção do látex}

As etapas da produção do látex, considerando as estradas já abertas são:

- numeração e plaqueamento das seringueiras

- divisão das árvores em bandeiras

- raspagem das bandeiras

- corte (sangria) da seringueira 
Este é o sistema tradicional extrativista da Amazônia, apenas realizado com maior controle sobre a produção de cada estrada e a numeração das árvores de seringueira.

O período de produção vai de maio a agosto e de outubro à novembro. Normalmente uma estrada é cortada uma vez a cada três dias.

\section{Produção de madeira}

A madeira é utilizada na defumação e nas estufas de secagem. Nas estufas normalmente a lenha utilizada é proveniente das áreas de roçados.

A área considerada para manejo é de 20 hectares. A produção da madeira ocorre em áreas de produção anual de um hectare, com um ciclo proposto de 20 anos. São localizadas as árvores que tenham diâmetro acima de $150 \mathrm{~cm}$. Para que uma espécie seja derrubada é necessário que exista mais duas árvores da mesma espécie. A derrubada é feita de maneira direcionada de forma a causar o mínimo impacto. As toras são seccionadas em discos de 15 a $20 \mathrm{~cm}$ de espessura, transportados manualmente até as unidades de produção e transformadas em cavacos.

As áreas de manejo estão divididas em florestas de várzea e florestas de terra firme. A economia local é baseada na agricultura de subsistência e produção de couro vegetal. Alguns produtores trabalham também com produção de canoa, artesanato de cipó e extrativismo da castanha.

A população mora nas margens dos cursos d'água em colocações definidas com base em estradas de borracha. As colocações são entendidas como o espaço geográfico onde estão localizadas as estradas de borracha, castanhais. Roçados e as casas das famílias. Medem em geral de 300 a 600 hectares. Os responsáveis pela área são pessoas que 
nasceram, ou se encontram há décadas, na região.

A população local é em sua maioria jovem e sem grupo doméstico constituído. A taxa de analfabetismo é superior a $60 \%$ na população acima de 14 anos. Para atendimento médico a população tem que se deslocar até Boca do Acre. Tem havido migração para dentro e para fora da Flona. A causa provável é a baixa no preço da borracha o que faz que as colocações distantes, apesar de boas produtoras de látex, sejam abandonadas em favor de áreas localizadas mais próximas aos grandes rios e a sede do município.

Aauditoria concluiu pela decisão favorável à certificação fazendo algumas observações. Entre elas:

- regularizar autorização oficial para extração da madeira

- regularizar documentação definitiva da terra

- melhorar as condições de trabalho no que se refere à exposição dos produtores á fumaça no processo de defumação das lâminas.

- resolver disposição adequada para resíduos (embalagens, pilhas, etc.)

- ampliar o mercado para o couro vegetal para garantir a sustentabilidade econômica do projeto.

- estimular o envolvimento e capacitação de mulheres e jovens na criação e produção de artesanato com couro vegetal, madeira e produtos florestais não madeireiros (sementes, cipós, etc.)

\subsection{A empresa Couro Vegetal da Amazônia e a Amazon Life}

O Projeto Couro Vegetal da Amazônia é o resultado da aliança formada pela Couro 
da Amazônia S.A., Instituto Nawa para o desenvolvimento do Extrativismos Sustentável daAmazônia e três associações de produtores:Associação dos SeringueiroseAgricultores da Reserva Extrativista do Alto Juruá (ASAREAJ) no Acre, Associação dos Produtores de Artesanato e Seringa (APAS) de Boca do Acre, no Amazonas, com extração na Floresta Nacional Mapiá-Inauiní e Associação dos Seringueiros Kaxinawá com extração na Terra Indígena do Rio Jordão, (ASKARJ).

O projeto Couro Vegetal daAmazônia tem como objetivo desenvolver, produzir e comercializar o couro vegetal, tecido emborrachado com látex da seringueira, nos estados do Acre e Amazonas, criando alternativas econômicas para os seringueiros.

Diversas áreas do Norte do Brasil se caracterizam pelo desmatamento crescente, concentração de propriedades e conflitos pela posse de terra. A atividade mais comum na zona rural é a extração da borracha. Porém os seringueiros são obrigados a vender toda a produção para intermediários, a preços baixos.

A atividade da empresa Couro Vegetal da Amazônia teve início em 1988.

No final da década de 80 , em especial o ano de 1988, foi marcante para o movimento ambiental no Rio de janeiro. Neste ano os ecologistas começaram a olhar com certa reverência para o que vinha acontecendo na Amazônia, com destaque para a luta dos povos da floresta. No Rio de Janeiro, uma grande passeata foi organizada pelos ambientalistas e um dos pontos máximos foi a afixação de uma grande faixa, num dos mais belos cartões-postais do mundo, o Pão de Açúcar. A faixa estampava a frase: Salve a Amazônia. O propósito da manifestação foi chamar a atenção para a luta dos seringueiros do Acre em defesa da floresta. Isso aconteceu um mês antes do assassinato do líder seringueiro, sindicalista e ativista ambiental Chico Mendes em 22 de dezembro de 1988.

Nesta época aconteceram várias mobilizações para apoiar os extrativistas da 
Influenciadas pelos movimentos de luta pela Amazônia e sensibilizados pela morte do sindicalista, os empresários JoãoAugusto Fortes e Maria Beatriz Saldanha se uniram para criar, em 1990, no Rio de Janeiro, uma das primeiras lojas brasileiras especializadas em produtos ecológicos, o Ecomercado. Era uma maneira de abrir novos mercados e criar alternativas econômicas para os seringueiros da Amazônia e colaborar com o movimento em defesa da floresta.

Os sócios da empresa foram contatados por seringueiros de Boca do Acre, AM, para apresentar o saco encauchado, uma espécie de bolsa de tecido impermeabilizado pelo látex, tradicionalmente usado pelos seringueiros para embalare transportaro látex colhido e suas bagagens pessoais.

Um lote de couro vegetal foi encomendado e com ele foram produzidos as primeiras bolsas e pastas que foram lançadas durante a realização da Rio 92. Porém tal qual aconteceu com os primeiros comerciantes de borracha natural, antes de ser conhecido o processo da vulcanização, os produtos foram devolvidos pelos clientes com a reclamação que estavam pegajosos e tinham odor desagradável.

Ficou clara a necessidade da utilização do processo de vulcanização para tornar o produto mais durável.

Para o aprimoramento deste material foram contratados especialistas que desenvolveram um processo tecnológico exclusivo que viabilizou o produto para o mercado internacional. O resultado foi o couro vegetal - Tree Tap Wild Rubber, que conferiu à borracha nativa ótimos padrões de qualidade enfatizando seu valor cultural e ecológico. O Tree Tap foi desenvolvido especialmente para a realidade dos seringais nativos da Amazônia para ser utilizados na confecção de bolsas, mochilas, pastas, artigos de vestuário, calçados, encadernações e revestimentos. 
A formalização da empresa Couro Vegetal da Amazônia S/A, sociedade anônima de capital fechado que produzia e comercializava os produtos em couro vegetal, se deu em 1994. A partir de então foi possível a obtenção de financiamento do BNDES, através do BNDESpar, para viabilizar o projeto, investir na tecnologia do produto e na infra-estrutura das áreas de produção. Até hoje este financiamento continua sendo pago através de renegociação da dívida, o que demonstra que até o momento o empreendimento não é totalmente auto-sustentável.

Durante os anos que se seguiram, produtores, associações e empresa trabalharam juntos no desenvolvimento do Tree Tap e sua colocação no mercado. Na Amazônia a estruturação das quatro atuais áreas de produção e treinamentos para capacitação de produtores.

Bia Salanha reconhece a importância, na viabilização deste projeto a existência de um movimento social organizado.

Em 1996, foi fundado o Instituto Nawa, entidade sem fins lucrativos criada para dinamizar parcerias entre associações de produtores, empresas, governo e ONGs, nacionais e internacionais.

A soma de experiência adquirida seja no estabelecimento de relações sociais, seja na aquisição de conhecimento técnico para atingir a qualidade necessária para a colocação do material no mercado de forma duradoura resultou num know how único que diferencia a empresa de forma inédita no mercado.

Para viabilização do empreendimento foi necessário um investimento no valor de U\$ 2.000.000 destinado á pesquisa, implementação de unidades produtoras, curso de capacitação. Parte deste capital foi feito com aporte dos próprios sócios sendo o restante proveniente do financiamento do BNDES através da BNDESpar. 
Em 1998 um contrato entre a Couro Vegetal daAmazônia e a Hermès de Paris - garantiu mais um ano de pesquisa. A empresa comprou grande quantidade de couro vegetal para a produção de pastas masculinas e estojos femininos com design próprio.

\subsubsection{Questões Sociais do Empreendimento}

Para avaliar os pontos positivos do projeto da Amazon Life, é importante aqui voltar ao conceito de "tecnologia social".

Segundo o Instituto de Tecnologia Social:

Quando falamos que uma tecnologia é social queremos destacar que ela carrega algo diferente das "outras" tecnologias, as chamadas tecnologias convencionais, criadas dentro de universidades e centros de pesquisa, no campo das chamadas "ciências duras".

A Tecnologia Social tem a ver com as soluções criadas na interação com a população como resposta aos problemas que ela enfrenta, levando em conta suas tradições, seus arranjos organizacionais, os saberes locais, o potencial natural da região, enfim, sua realidade histórica, econômica, social e cultural.

Ela não se define só pelos resultados e impactos que produz. A Tecnologia Social é principalmente um modo de fazer, um modo de produzir conhecimento, que presta atenção em valores como a participação e o aprendizado, a disseminação de informações e do conhecimento entre todas as partes envolvidas, a transformação das pessoas e da realidade social, entre outros aspectos, procurando caminhar para o desenvolvimento socioeconômico sustentável.

A Tecnologia Social se vincula, assim, à ampliação da cidadania e à inclusão social, porque possibilita a aprendizagem, a transformação da sociedade, e que os instrumentos de conhecimento sejam apropriados por aqueles que, ao longo da História, não tiveram acesso ao sistema de Ciência e Tecnologia.

Sendo assim se por um lado o projeto da Amazon Life é geradora de renda para uma população tradicional, de outro ao registrar a patente do processo tecnológico da produ 
ção do couro vegetal impede a possibilidade de expansão dos negócios que não estejam vinculados à empresa.

A Couro Vegetal da Amazônia garante a compra do material e paga aos produtores, pelas lâminas entre $R \$ 6,00$ e $R \$ 10,00$ (valores do ano 2000)

\subsubsection{O design da Amazon Life}
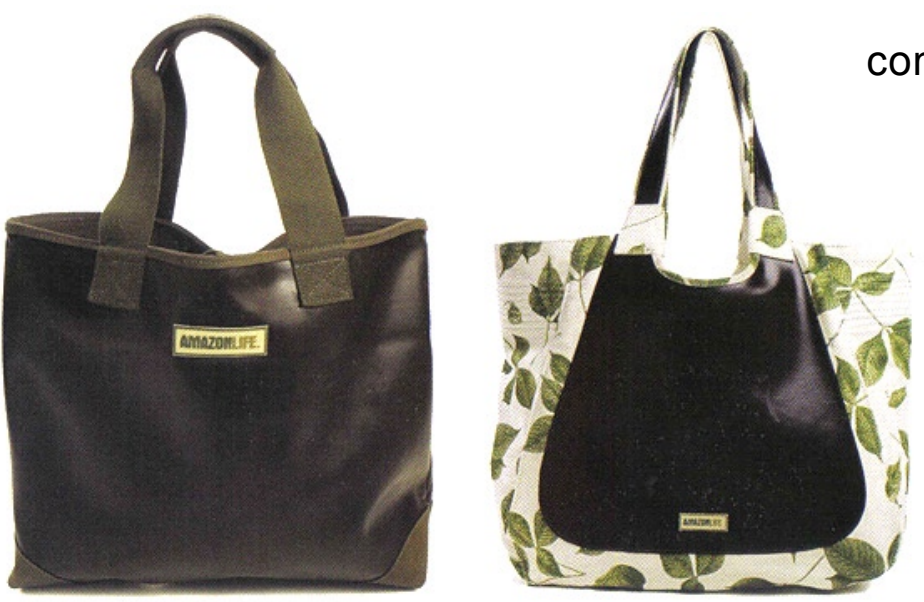

Figura 8:

A diferença da Amazon Life em relação com outras iniciativas de produtos de ecodesign é que a empresa se caracteriza pelo design e qualidade de seus produtos.

Por meio de parcerias, melhorou a tecnologia de produção do couro vegetal colaborando na imagem, na durabilidade e no odor do produto.

Estabeleceu um plano estratégico de negócios que envolve a área comercial mas também a imagem coordenada de design de produto e comunicação visual
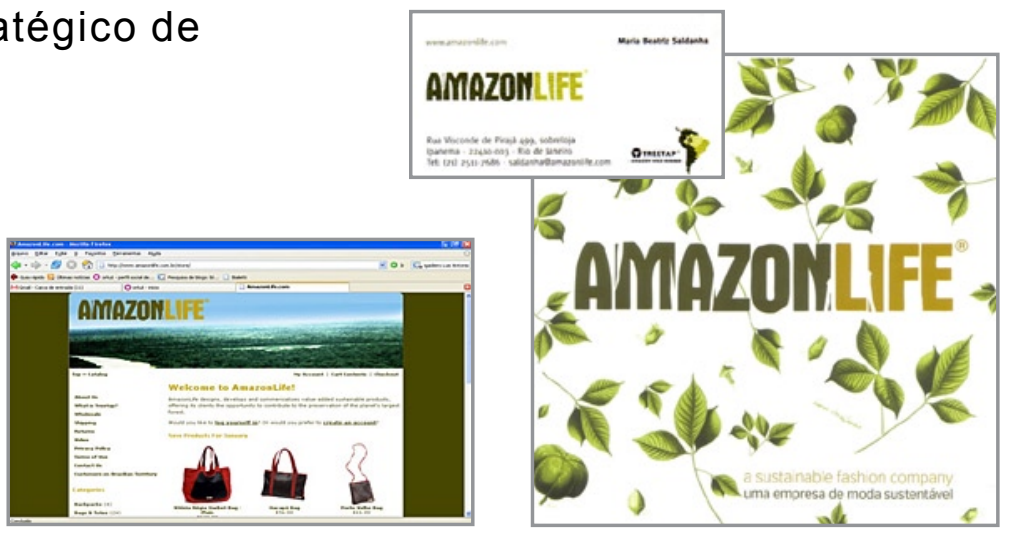
incluindo criação e apli- 
O design das peças apesar de contemporâneo não segue modismos sendo possível encontrar em linha os primeiros modelos desenvolvidos pela empresa.

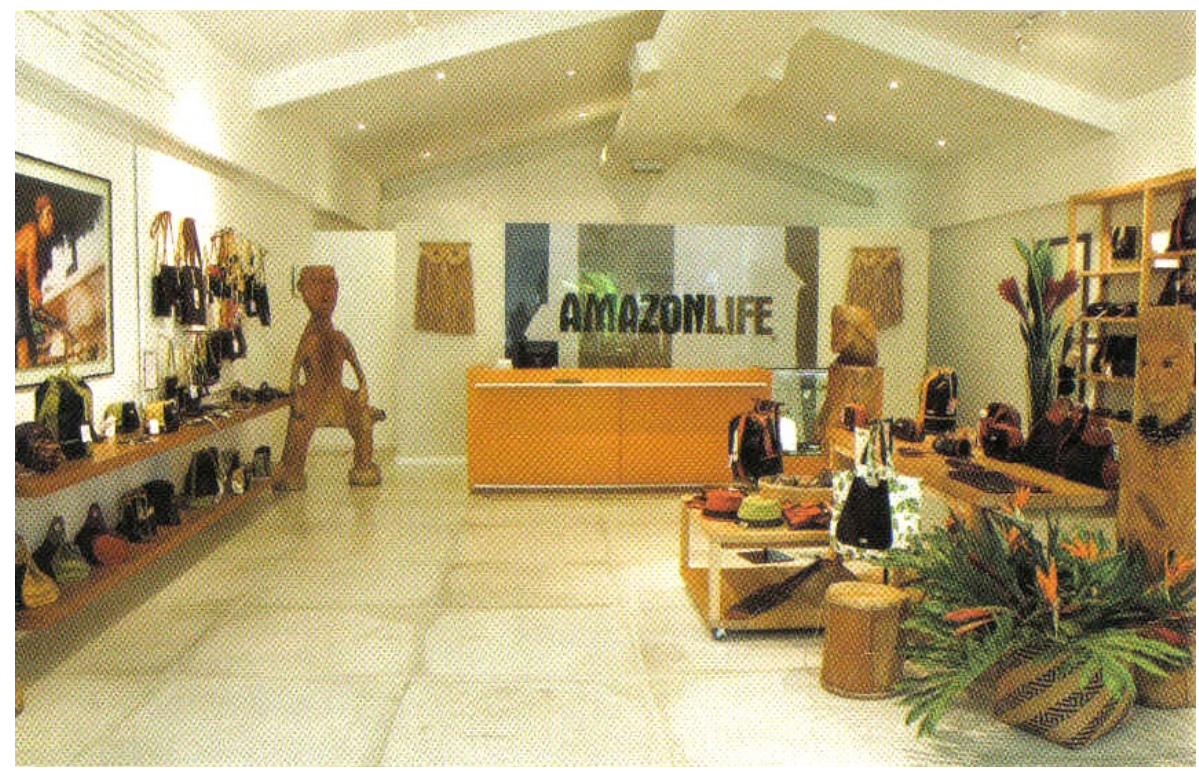

As cores tem uma tendência de tons que remetem à natureza. $\mathrm{O}$

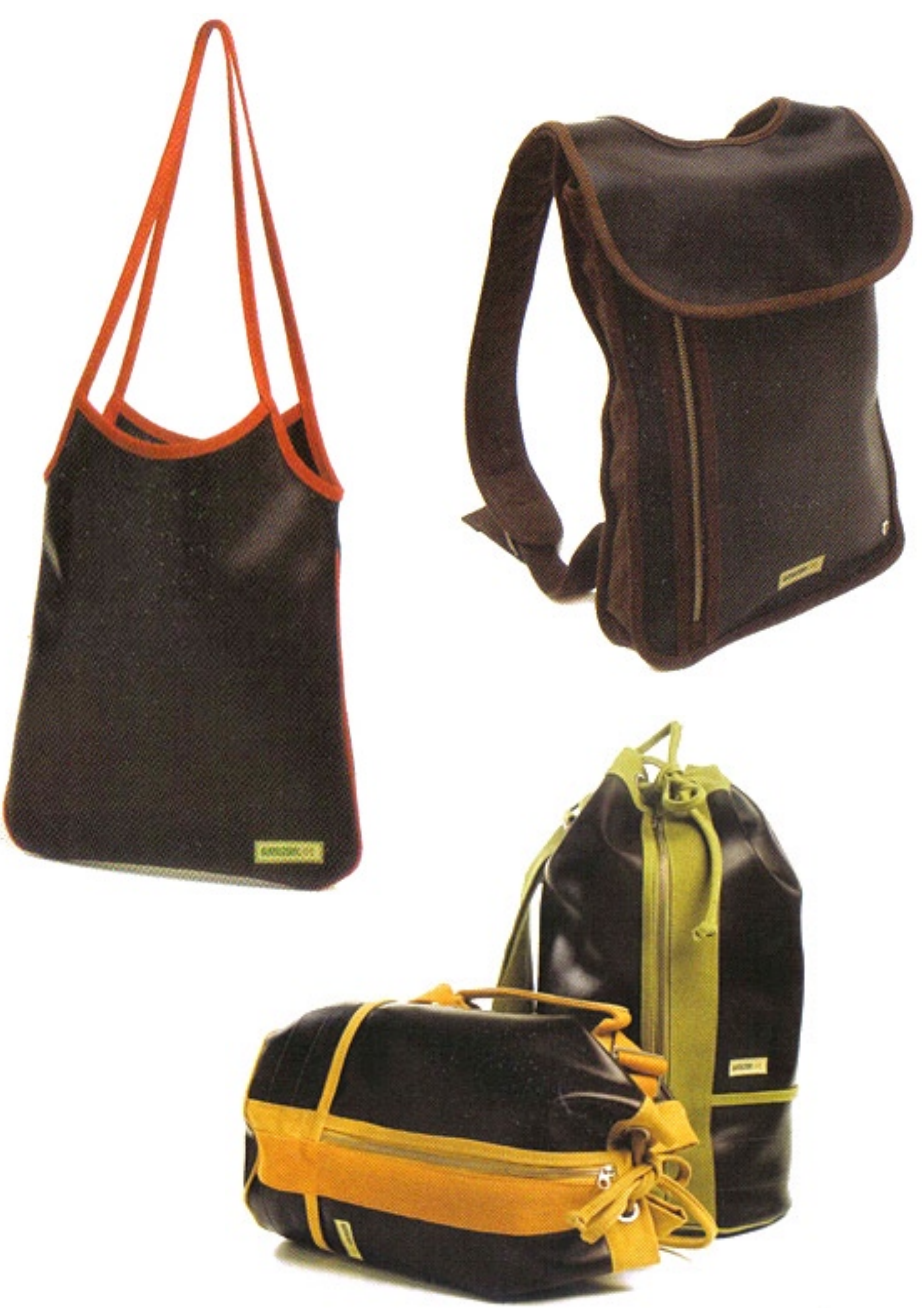
material complementar principal é o algodão tingido em várias tonalidades. Todas as bolsas tem ótimo acabamento e prima pelo cuidado nos detalhes, como a presença de uma etiqueta interna que possui um mapa que localiza a área de extração do látex na Amazônia. Tanto no catálogo comercial quanto no site da empresa a história do produto pode ser encontrada conectada às comunidades da Amazônia e preservação da floresta.

Concluindo, é um produto que os compradores se afeiçoam pela sua história e por isso não entram na categoria de descartáveis. 


\section{AVAliação de Ciclo de Vida do Produto}

\section{1 - Indicadores de Sustentabilidade}

Um indicador é uma unidade de medida de determinado fenômeno. Por exemplo, a temperatura do corpo é um indicador da saúde de um paciente.

PIB (Produto Interno Bruto), IDH (Índice de Desenvolvimento Humano), Taxa de Mortalidade, Índice de Escolaridade, Renda Per Capita, Índice de Concentração de CO2 na Atmosfera são indicadores econômicos, sociais e ambientais.

Na Agenda 21 já estava expressa a necessidade de determinar alguns indicadores de sustentabilidade pois o números relativos ao PIB ou a quantidade de emissões atmosféricas não são suficientes para construir indicadores de sustentabilidade. Com a introdução do conceito de espaço ambiental foi possível a concretização da noção de sustentabilidade (sustainability) ou capacidade de futuro (Zukunftsfähigkeit): a manutenção dos fundamentos naturais da vida e uma justa divisão da sua limitada possibilidade de utilização.

\footnotetext{
"É necessário elaborar indicadores de desenvolvimento sustentável, de maneira a criar fundamentos sólidos para tomada de decisão em todos os níveis para contribuir para uma sustentabilidade auto reguladora dos sistemas integrados ambiental e de desenvolvimento. (Agenda 21, par. 40.4.)
}

Porém unir grandezas de diferentes aspectos: ecológicos, sociais, econômicos e institucionais representa um problema de grande complexidade. Várias tentativas têm sido realizadas neste sentido. AUNCSD - Comissão das Nações Unidas para o Desenvolvimento criou algumas propostas de sistemas de indicadores.

Considerando a complexidade da criação de indicadores de sustentabilidade, a escassa existência de exemplos a serem seguidos, principalmente se aplicado ao projeto de 
produto (a maioria dos exemplos se refere construção de índice de uma empresa, uma cidade, uma pessoa, uma população), o presente estudo se limitará a um indicador de impacto ambiental, que poderá ser integrado futuramente a um sistema geral de indicador de sustentabilidade.

\subsection{A ACV - Avaliação do Ciclo de Vida do Produto}

Para a avaliação do impacto ambiental de um produto, a metodologia da ACV é a mais segura e promissora. (Manzini e Vezzoli, 1998).

Introduzir os requisitos ambientais no projeto de produto aumenta a complexidade da atividade de projeto porque é necessário a incluir maior quantidade de informações e ainda faltam experiências consolidadas e instrumentos apropriados de análise. As questões ambientais devem ser integradas desde o início do processo de projeto para dar suporte à tomada de decisões, que serão as mais importantes do processo total. A atividade do designer deve estar comprometida desde a etapa inicial e para projetar o profissional deve dispor de informações e métodos de análise, medidas de avaliação e instrumentos de suporte para avaliar as conseqüências de suas decisões.

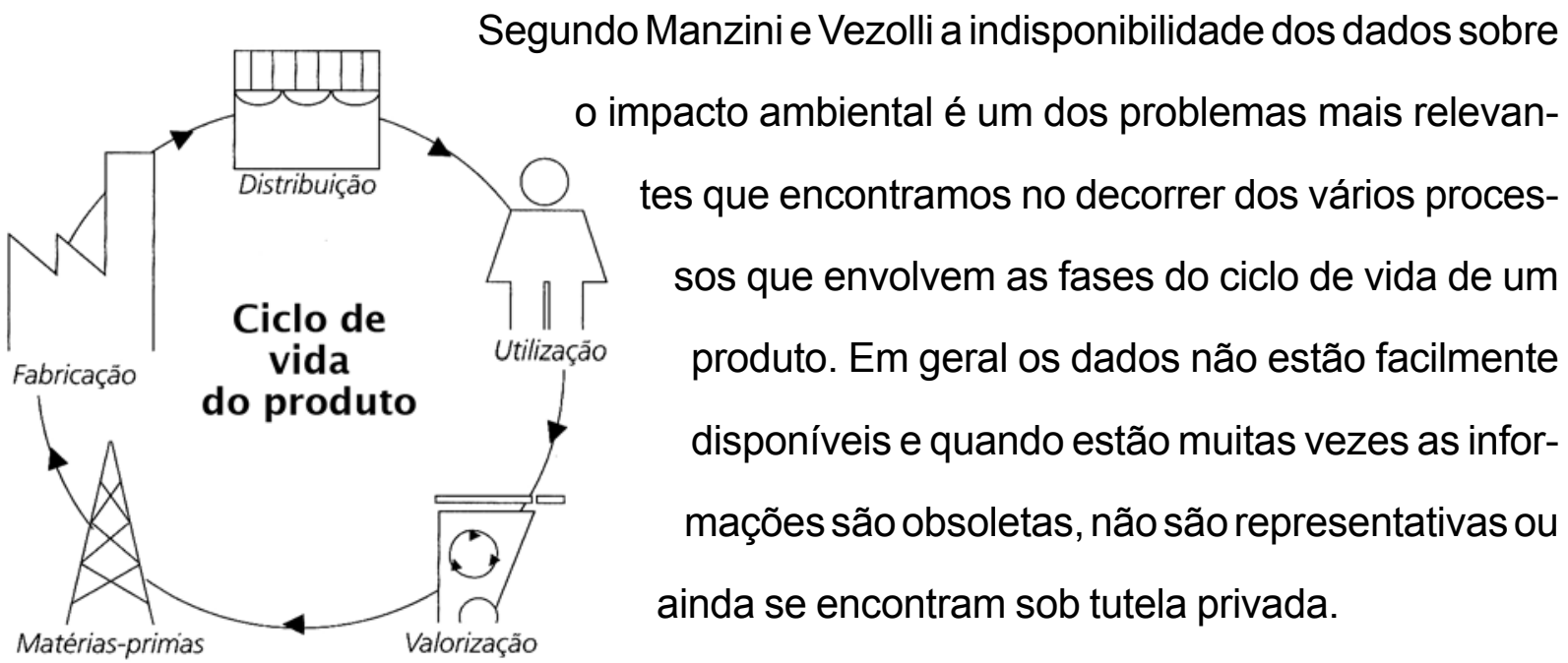


É necessário então trabalhar para a obtenção de dados detalhados sobre a origem, a produção a distribuição dos materiais e mais adiante de informações à respeito da transformação destes materiais em produtos, do seu potencial risco no impacto ambiental e, dos seus efeitos para a saúde durante toda a sua fase de produção, como também durante se uso e na eliminação dos produto.

Para administrar estas informações é importante a utilização de instrumentos eficazes na gestão das informações e de suporte nas decisões projetuais. Instrumentos de informática como, por exemplo, CAD (Computer Aided Design) e CAM (Computer Aided Manufacturing) devem estar integrados ao projeto de produto. Com a inclusão do ACV a atividade de projeto de produto se torna mais complexa e interdisciplinar.

Depois de fazer o levantamento das informações é necessário confrontá-las e estabelecer relações entre:

- sistemas de produção, consumo e ambiente.

- os vários atores envolvidos no sistema de desenvolvimento dos produtos.

- entre estes atores e os que estão evolvidos no ciclo de vida dos produtos.

Fica então claro que as mudanças necessárias para a transição para a sustentabilidade são de ordem sistêmica e exigem mudanças tecnológicas, sociais e culturais. Para que isso ocorra a utilização da informática se torna um instrumento imprescindível capaz de armazenar, circular, confrontar, elaborar e apresentar de várias maneiras possíveis (com diferentes interfaces), um grande número de informações. Ou seja, a utilização da informática é necessária pela sua capacidade de administrar o aumento da complexidade da atividade de projeto. 


\subsection{Os desafios para o designer}

O designer possui limitações na sua área de atuação porém pode contribuir na elaboração de alternativas para o modelo atual de desenvolvimento.

A questão crucial é o da oferta de possíveis alternativas pois são essas alternativas (isto é, uma nova geração de produtos e serviços intrinsecamente mais limpos) e seu sucesso (isto é, o fato de elas serem efetivamente praticáveis) que vão decidir o tempo e os modos da transição para a sustentabilidade. (idem).

Projeto e Desenvolvimento de Produto Etapas típicas e ações para integração de aspectos ambientais

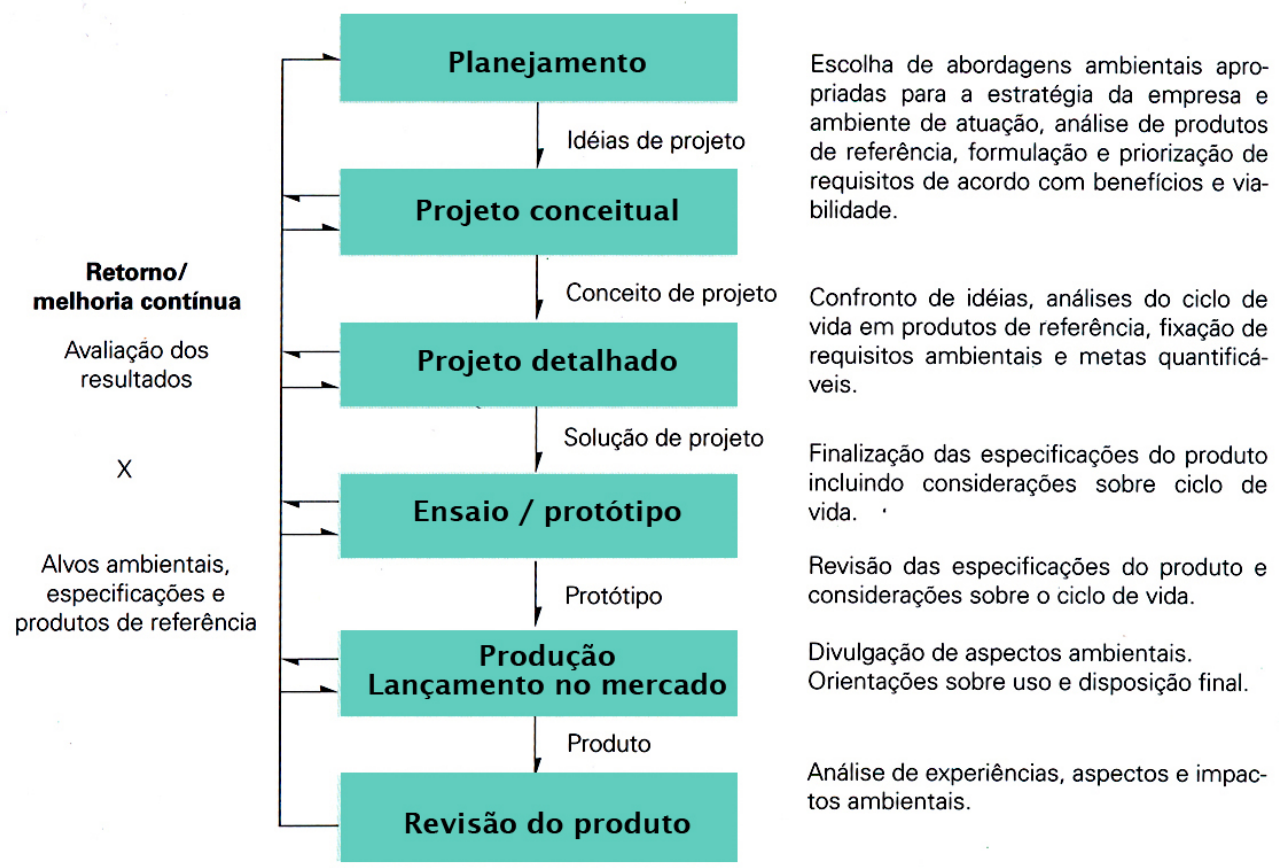

Figura 13: Esquema de etapas críticas para integração dos aspectos ambientais no projeto e desenvolvimento do produto. Fonte: ISO 14.062 
$\mathrm{Na}$ busca da sustentabilidade, tecnologia, design e marketing devem estar unidos. $\mathrm{O}$ desafio está em conseguir comunicar à sociedade a gravidade do problema ambiental de maneira a aumentar a capacidade do indivíduo de reconhecer e praticar as atitudes alternativas, mesmo quando são contrárias a comportamentos e critérios de valores já estabelecidos.

Apesar de não poder criar lei ou obrigar as pessoas a consumir determinados produtos, 0 designer pode atuar de maneira crítica aos modelos existentes e criar produtos com novos conceitos. Pode, e deveria, contribuir para aumentar o número de alternativas viáveis, técnica e economicamente, de estratégias de soluções para os problemas; intervir na definição de resultados, dando-se o direito de compreender, agir e até errar; imaginar soluções ainda não expressas claramente, intervir no âmbito cultural, de valores, de critérios de qualidade e em visões de mundos possíveis para tentar influenciar o mundo existente. Dentro da limitação de sua atuação deve propor oportunidades que tornem praticáveis estilos sustentáveis de vida trabalhando em colaboração com as empresas que são os atores sociais que detém os maiores recursos em termos de investimento, conhecimento, organização e capacidade de tomar iniciativa.

\subsection{Ciclos Ecológicos e ACV}

Para evitar o uso excessivo de recursos é necessário transformar os fluxos de materiais unidirecionais em ciclos ecológicos reduzindo o consumo de matérias primas e energia.

Depois de extraídas as matérias primas são transformadas em produtos. Estes produtos, depois de utilizados, se transformam em resíduos e então são devolvidos à biosfera. Sendo assim são criados dois impactos negativos, um sobre o esgotamento de recursos naturais e outro sobre o aumento de resíduos que são fontes de poluição. 
Esquema linear unidirecional da economia

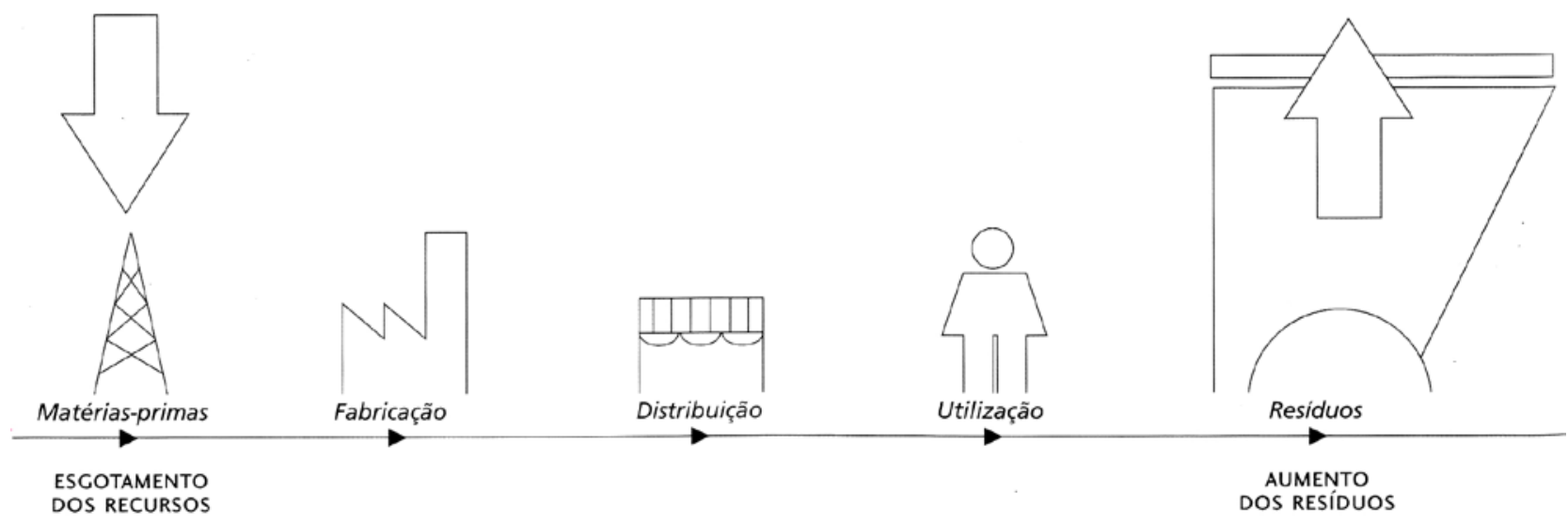

Figura 14: Esquema Linear Unidirecional da Economia. Fonte: $\mathrm{O}_{2}$ France

No ciclo industrial ecológico é importante observar que:

- a utilização de recursos renováveis deve ser coerente com a capacidade de regeneração da natureza e dos ecossistemas;

- o consumo de recursos não renováveis deve ser minimizado;

- o projeto de produtos e serviços deve gerar o mínimo impacto possível sobre o meio ambiente;

- os produtos devem ser projetados para serem reciclados ou reutilizados;

- a reutilização e a reciclagem devem ser feitas da forma mais eficiente possível;

- os resíduos industriais que não podem retornar ao ecociclo devem ter uma disposição segura a longo prazo.

O conceito de Ciclo de Vida do Produto se baseia em um conceito circular, fechado: que vai do berço ao túmulo, ou do berço ao berço uma vez que se existirem resíduos eles devem ser reintegrados à produção.

Para realizar a ACV é necessário compreender de onde vieram as matérias primas utilizadas, para onde irão os produtos fabricados, os subprodutos que são gerados e os re 
síduos do processo como também os efeitos das emissões geradas no meio ambiente.

A abordagem em Ciclo de Vida do Produto é fundamental para avaliar seu impacto no meio ambiente. Todas as etapas devem ser avaliadas desde a concepção do produto: na escolha das matérias primas,das tecnologias, dos processos de fabricação, da organização da logística e no seu uso e descarte que deve facilitar sua reintegração no ciclo de outro produto.

Aemissão zero é a estratégia da produção limpa. Há uma redução máxima de saídas e a venda das emissões restantes a outras empresas como matérias secundárias. A utilização das entradas (energia e recursos) é otimizada e os produtos são concebidos levando em consideração as saídas.

Próximo a este conceito está o do ciclo fechado, quando a empresa controla todas as fa-

\section{Fluxo fechado}
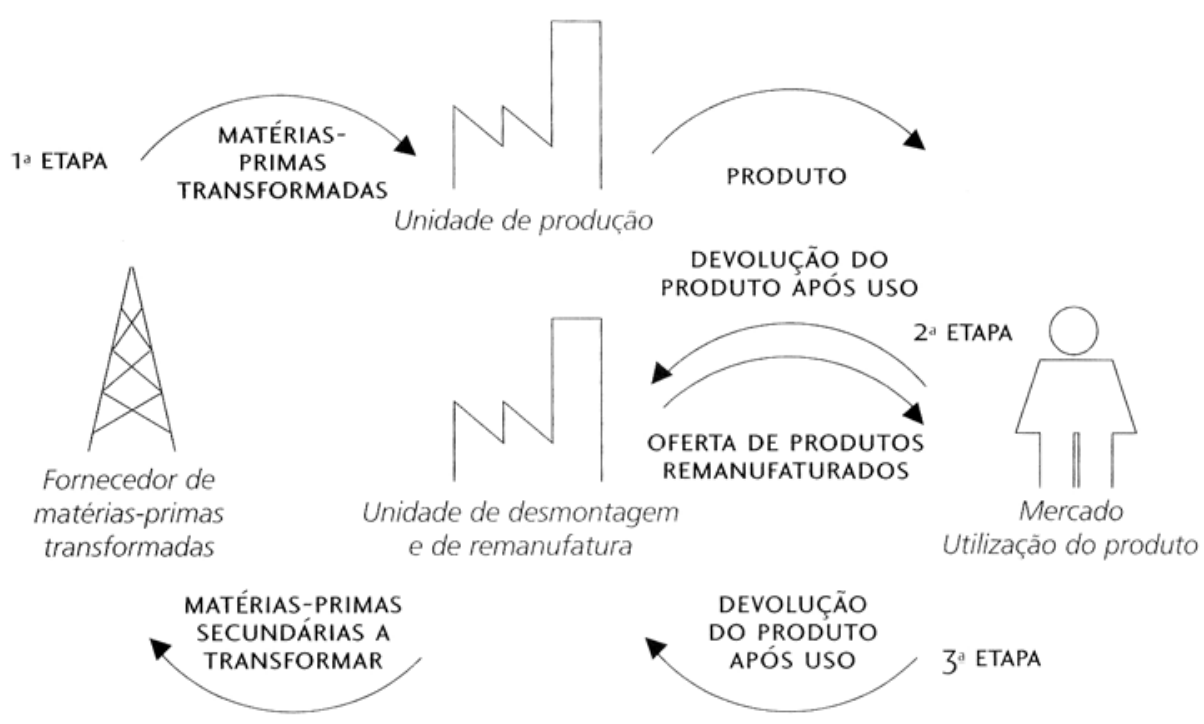

Figura 15: Esquema de Fluxo Fechado. Fonte: $\mathrm{O}_{2}$ France 
devolução ao mercado. As empresas se tornam produtoras de matérias primas secundárias e de serviços, diminuindo custos e evitando taxações sobre produção de resíduos.

Integrar o conceito de ciclo em um produto significa valorar todas as etapas do processo incluindo a reutilização do produto, ou de um de seus componentes, na recuperação de energia pela incineração ou de matérias primas via reciclagem ou no caso de ser de origem vegetal utilizar para compostagem.

Os produtos deveriam ter o maior tempo de duração possível dentro dos sucessivos ciclos de utilização.

\subsection{O Conceito de ACV}

A Avaliação do Ciclo de Vida de um produto é um instrumento de identificação e avaliação dos impactos energéticos, dos impactos ambientais e dos impactos potenciais associados a todas as fases do ciclo de vida de um produto, processo, atividade. Baseado na análise dos impactos é possível determinar uma oportunidade de melhoria. A avaliação compreende o ciclo de vida inteiro do produto, processo ou atividade: a extração e transformação da matéria prima, a fabricação do produto e a distribuição, o uso, o reuso, a estocagem, a reciclagem e o descarte.

A ACV de um produto permite uma contabilização ambiental que leva em consideração as retiradas de recursos naturais e energia da natureza e as "devoluções" para a mesma e a avaliação dos impactos ambientais potenciais relativos às entradas e saídas do sistema.

A contabilização tem início na natureza em termos de utilização de recursos naturais 
como água, minério, floresta, petróleo e atmosfera e considera todas as transformações intermediárias necessárias para obtenção do produto estudado como processamentos, distribuição e transporte, reciclagem e disposição final.

A contabilidade também é finalizada na natureza, novamente expressa em termos de resíduos gerados, subprodutos e emissões para a água, terra e ar.

As emissões do sistema são avaliadas quanto aos impactos potenciais em relação ao uso de recursos naturais, saúde humana e conseqüências ecológicas (como efeito estufa, uso de recursos renováveis ou não, acidificação, etc.).

A ACV é abordada dentro de uma ótica macro onde são consideradas as inter-relações entre os diversos sistemas, porém deve-se considerar que apesar da abordagem holística, na prática constitui-se uma ferramenta normatizada pela ISO 14040 que contabiliza recursos utilizados e emissões geradas e avalia os impactos ambientais potenciais. Apesar de ampla, não se aplica a todas as necessidades como, por exemplo, avaliação de risco, ou aspectos econômicos ou sociais. Para um gerenciamento ambiental adequado deve estar integrada a outros instrumentos de gestão ambiental.

Por ter uma abordagem ampla é um instrumento complexo de análise. Uma das dificuldades é que é necessário considerar que o impacto de um produto não é determinado por ele mesmo, ou pelo material utilizado na sua fabricação, mas pelo conjunto de processos que o acompanha durante todo seu ciclo de vida. Este modelo inclui algumas incertezas, como por exemplo, na definição do comportamento do usuário em relação ao produto ou como ele procede para descartá-lo. Depois de considerar o perfil do ciclo de vida inteiro do produto ficam dúvidas sobre os reais impactos dos processos utilizados pois o conhecimento do ambiente que nos circunda ainda é limitado e as relações entre causas e efeitos não são facilmente identificáveis. 
Entre os limites desta ferramenta está a possibilidade de inclusão ou não de determinadas etapas. Isto ocorre para evitar que a avaliação se transforme em um processo inacabável pela sua extensão e pela abrangência de informações. A avaliação tem restrições geográficas e temporais. O estudo abrange uma determinada região geográfica em um determinado momento. Por isso nem sempre é possível exportar para outro país os dados de determinada de análise quando, por exemplo, há variação de matriz energética. Ou quando um estudo foi executado anos atrás, pois pode ter ocorrido variações.

Apesar de que alguns estágios do ciclo de vida de um produto podem ser excluídos, esta seleção de etapas deve ser declarada e justificada no objetivo e escopo do estudo de maneira clara e transparente.

É recomendado que não sejam excluídas as seguintes fases da avaliação:

- seqüência principal do processo produtivo: entradas e saídas de energia, água e utilização de recursos naturais (matéria-prima ou insumo);

- transporte e distribuição;

- dados associados à geração de energia;

- utilização de combustíveis para geração de energia, calor e transporte;

- subprodutos gerados no processo produtivo;

• disposição de resíduos sólidos. 


\subsection{Fases de Execução da ACV}

As fases de uma ACV segundo a norma NBR ISO 14040 são quatro:

\section{1 - Definição de Objetivo e Escopo}

Nesta etapa são definidas a finalidade da análise, a unidade funcional, os limites do sistema estudado, os dados, os itens pré-definidos, os procedimentos de verificação.

Segundo a publicação Avaliação do Ciclo de Vida - Princípios e Aplicações deverão ser respondidas as seguintes perguntas:

- Porque realizar o estudo?

- Para quem o estudo se destina?

- Quais as fronteiras do estudo?

- Quais categorias de impacto serão consideradas e qual unidade funcional será considerada?

- Quais são os critérios de avaliação do impacto ambiental?

- Quais os critérios de alocação de consumo/emissões em processos que geram mais de um produto?

- Como o resultado será divulgado?

\section{2 - Análise de Inventário.}

São identificados e quantificados as entradas (consumo de recursos, energia, etc.) e saídas (emissões na atmosfera, na água, etc.). 
Nesta fase são feitos o levantamento, a compilação e a quantificação das entradas e saídas do sistema em termos de energia, recursos naturais e emissões para água terra e ar considerando as categorias de impactos e as fronteiras pré-definidas.

\section{3 - Avaliação de impacto.}

Procede-se à uma caracterização qualitativa e quantitativa das conseqüências ambientais ao longo de todas as fases do ciclo de vida do produto;

Pode ser dividida em três etapas distintas:

- classificação: na qual se opera uma agregação quantitativa de diversos impactos ambientais em determinada categoria: efeito estufa, eutrofização, consumo de energia, etc. em geral por meio de indicadores;

- avaliação: na qual se efetua uma comparação qualitativa das várias alternativas ou a determinação de um índice sintético final baseado na hierarquização dos diversos impactos (por exemplo um sistema de peso) ou de redução a um valor convencional;

- validação, na qual se efetua uma análise de sensitividade dos resultados baseados na quantidade de dados, dos itens pré-definidos, dos sistemas de classificação e valoração utilizados.

Nesta etapa procura-se entender a avaliar a intensidade e o significado das alterações potenciais sobre o meio ambiente associados ao consumo de recursos naturais e energia e da emissão de substâncias relativas ao ciclo de vida do produto.

Segundo a ABNT NBR ISO 14040 esta avaliação deve incluir três etapas: classificação, caracterização - de caráter científico - e ponderação - que inclui julgamentos subjetivos, políticos ou normativos. 


\section{Classificação}

- Nesta etapa cada parâmetro do inventário é associado a uma categoria de impacto, como efeito estufa, acidificação, etc.

\section{Caracterização}

- Nesta etapa são colocados em uma mesma base de dados diferentes parâmetros que contribuem para uma mesma categoria de impacto, considerando o efeito de cada um. Por exemplo: todas as substâncias que contribuem para o efeito estufa são somados na base de massa de $\mathrm{CO} 2$ equivalente, que é uma grandeza calculada a partir do potencial do aquecimento global de cada substância, parâmetro já aceito pela comunidade científica internacional.

\section{Ponderação}

- Nesta etapa as categorias de impacto são somadas entre si, de acordo com o grau de importância para o meio ambiente previamente definida, buscando-se um indicador único de desempenho ambiental para o produto. Embora grandes debates científicos tenham sido gerados até o momento na busca de metodologias para a ponderação, não se obteve nenhum acordo internacional geral sobre metodologias mais adequadas para esta finalidade.

Principais categorias que devem estar presentes na avaliação de impactos ambientais:

\section{Consumo de Recursos Naturais}

Avaliação do uso de água e a extração de recursos naturais para ser utilizado como fonte de energia e como matéria prima.

\section{Consumo de Energia}

É um dos indicadores mais importantes pois está associado ao uso de recursos natu- 
e às emissões para o ar e para água. A queima de combustíveis produzidos a partir de fontes não renováveis como petróleo e carvão mineral além de contribuir para o esgotamento de recursos que são finitos, emite no ar CO2, SO2 e NOx contribuindo em outras categorias de impacto como efeito estufa, formação de chuva ácida, formação de fumaça oxidante além de prejudicar a saúde da população. Aenergia nuclear oferece risco de contaminação por radioatividade em caso de acidente, consome recursos naturais e produz lixo perigoso. A hidrelétricas produzem energia limpa porém necessita ter disponibilidade de água e terra, alterando o ecosistema local. Restam as energia alternativas como a aeólica e solar.

\section{Efeito Estufa}

A intensificação do efeito estufa decorrente da ação do homem pode trazer como conseqüência o aumento da temperatura média do globo terrestre gerando chuvas intensas em áreas consideradas desérticas, falta de água em regiões férteis e o aumento do nível dos oceanos devido ao derretimento das geleiras e calotas polares.

\section{Acidificação}

Ocorre quando substâncias emitidas no ar, como dióxido de enxofre (SO2) e óxido de nitrogênio (NOx), são disolvidas na água da chuva e combinam-se com outros elementos formandoácidos que atingem a superfície da terra e alteram a composição química do solo e das águas, interferindo nas lavouras, florestas, rios, lagos, além de causarem danos em estruturas metálicas e edificações. O SO2 é proveniente principalmente da queima de combustíveis fósseis nos processos industriais e o NOx da queima de combustíveis especialmente durante o transporte.

\section{Toxidade humana}

Aemissão para o ar, água ou solo de substâncias consideradas tóxicas, como os compostos aromáticos(tolueno, benzeno, xileno, fenol, etc.), metais pesados (chumbo, cádmio, cromo, arsênio, mercúrio, etc.), tetracoleto de carbono, idrocarbonetos halogenados 
(tricloro metano, etc.) podem causar problemas à saúde humana quando inaladas ou ingeridas. Alimentos contaminados por mercúrio podem causar encefalite, cegueira e retardo mental. Podem ainda causar doenças a disposição não controlada de lixo hospitalar, embalagens de pesticidas, resíduos industriais de natureza tóxica e a utilização indiscriminada de pigmentos e corantes que contém metais pesados.

\section{Ecotoxidade}

A emissão de materiais pesados (etilbezeno, hidrocarbonetos, alogenados, inseticidas, hidrocarbonetos aromáticos policíclicos, fenol, etc.) no ar, na água e no solo tem efeito negativo sobre a flora e a fauna.

\section{Nutrificação e eutroficação}

É a adição de nutrientes no solo ou na água que faz com que haja um aumento da produção de biomassa (microorganismos). A conseqüência é a redução do oxigênio disponível fato que afeta a flora e a fauna. O nitrogênio e o fósforo são os principais elementos deste fenômeno porém também estão incluídos amônia, nitratos, nitritos, compostos nitrogenados, óxidos de nitrogênio, fosfatos, resíduos de alimentos, óleos, gorduras, etc. Formas indiretas de quantificação destes fenômenos são as determinações de DBO - Demanda Bioquímica de Oxigênio - que é a quantidade de oxigênio necessária à degradação biológica de resíduos orgânicos contidos numa determinada porção de água e a DQO - Demanda Química de Oxigênio que é a quantidade de oxigênio necessária a uma degradação puramente química de resíduos orgânicos contidos numa determinada porção de água, se intervenção de microorganismos.

\section{Fumaça fotoquímica oxidante}

É o nevoeiro causado pela reação entre óxidos de nitrogênio (NO2) e substâncias orgânicas voláteis sob a ação de raios ultravioletas que gera compostos oxidantes fotoquímicos. Esta névoa afeta a saúde da população, produzindo um aumento no número de doenças respiratórias, principalmente em grandes centros urbanos onde é mais difícil a 
da nuvem de poluentes que foi formada.

\section{Redução da camada de ozônio}

A camada de ozônio está localizada na estratosfera, entre 20 e 35km de altitude da superfície terrestre, possui uma espessura de $15 \mathrm{~km}$, e funciona como uma espécie de filtro que protege a Terra da radiação ultravioleta emitida pelo sol.O ozônio é um gás rarefeito formado pela exposição de moléculas de oxigênio à radiação solar ou a descargas elétricas. A diminuição dessa camada permite que a radiação ultravioleta chegue à terra com maior intensidade. Esta radiação é nociva á saúde e causa principalmente câncer de pele e doenças oculares, como a catarata.

Nos últimos anos cientistas identificaram que a camada de ozônio está diminuindo, sobretudo nos pólos, e que apresenta alguns "buracos". Acredita-se que os compostos de clorofluorcabono (CFC) sejam os principais responsáveis pela distruição da camada de ozônio. Desde 1987 vários tratados e acordos internacionais formam assinados com o objetivo de reduzir a emissão de CFC até ser totalmente extinto em 2010. Desde então muitos processo produtivos e tecnologias foram alterados ou desenvolvido para eliminar o uso de CFC. Estes gases são utilizados como propelente em alguns tipos de aerossóis, em mistura de agente expansor para plástico, em chips de computadores, em solventes utilizados pela indústria eletrônica e principalmente em aparelho de refrigeração como geladeiras e ar condicionado.

\section{4 - Interpretação}

Tendo como base a interpretação dos resultados da análise, se avaliam e se identificam as melhores soluções para diminuir os impactos energéticos e ambientais.

Nesta fase são relacionados ao Objetivo e Escopo os resultados obtidos na Análise de Inventário e na Avaliação de Impacto. 
Para que Objetivo e Escopo sejam alcançados, a qualidade de dados utilizados no estudo deve ser analisada de maneira crítica quanto ao período de tempo, área geográfica e tecnologias cobertas, precisão, completeza e representatividade, consistência e reprodutibilidade dos métodos usados ao logo do ACV, fontes de dados e sua representatividade e incerteza da informação.

Uma ACV é de natureza interativa - por sua natureza dinâmica pode ser continuamente revisto e modificado - à medida que as informações adicionais forem sendo coletadas ou quando o sistema for conhecido melhor, o escopo pode sofre modificações.

As conclusões da ACV devem indicar possíveis melhorias ambientais através da:

- identificação, avaliação e seleção de opções para melhoria ambiental;

- identificação de pontos críticos do ciclo de vida que precisam ser melhorados pela análise do inventário;

- estimativas de ganhos ambientais que podem ser obtido seguindo as melhorias sugeridas como: aumento de eficiência energética, diminuição da geração de resíduos ou, melhor aproveitamento dos que forem inevitáveis, implantação de sistemas de filtragem e de tratamento de efluentes, etc. 


\section{7 - Informações qualitativas para ACV do Couro Vegetal produzida pela APAS}

Por questões de abrangência e objetivo desta dissertação serão levantadas informações relativas à da primeira e a segunda etapa do ACV, ou seja: Definição de Escopo e Objetivo.

É preciso esclarecer que o Inventário representa somente uma das fases do ACV. Este trabalho é essencialmente descritivo e a ACV é uma avaliação ampla dos impactos resultantes avaliados durante todo o ciclo de vida do produto. Porém acompanhando o raciocínio da medição da temperatura de um doente com febre, esta medição é importante e conclusiva sobre o estado de saúde do paciente, mas antes mesmo da mediçãoé possível perceber o mal funcionamento do organismo somente pela sensibilidade. Percebemos que alguma coisa não está funcionando bem numa cidade quando notamos uma grande quantidade de mendigos pelas ruas, mesmo sem conhecer o IDH daquela cidade. Com isso quero ressaltar a importância de uma ACV qualitativa que avalia, mesmo sem quantificar, os impactos ambientais de um produto desde seu nascimento até seu destino final. Aconsciência dos efeitos negativos permite que os mesmos sejam minimizados já na fase de projeto do produto.

\subsection{1 - Definição de Objetivo e Escopo}

Para definição de objetivo foram respondidas as questões sugeridas em Avaliação do Ciclo de Vida-Princípios e Aplicações no que se refere à produção do couro vegetal pela APAS e sua utilização na manufatura de produtos de uso pessoal pela Couro Vegetal da Amazônia.

Questionário respondido segundo escopo acadêmico deste trabalho: 


\section{- Porque realizar o estudo?}

Para avaliação de impacto ambiental, identificando pontos críticos e possíveis melhorias.

\section{- Para quem o estudo se destina?}

Para uso interno como instrumento de validação do produto como "produto ecológico". Para que a empresa Couro Vegetal da Amazônia tome consciência dos pontos críticos em relação à cadeia produtiva de seus produtos uma vez que a empresa atua no segmento do "mercado verde" e por desconhecimento de todo o processo poderia estar incorrendo em alguma decisão incorreta em relação à matérias primas ou processos.

\section{- Quais as fronteiras do estudo?}

Opresente estudoestárelacionadoà produção das lâminas de Couro Vegetal Produzidas pela APAS - Associação de Produtores de Artesanato e Seringa da Boca do Acre - AM. Serão incluídas no estudo as fases de obtenção da borracha natural, que é matéria prima que caracteriza o couro vegetal, e tratdo com menos importância o algodão, que é o suporte de aplicação do látex; o processamento para produção do couro vegetal, o transporte de Boca do Acre ao Rio de Janeiro, a transformação do material em produto (bolsas e outros acessórios), embalagem, venda através da loja, distribuição para clientes internacionais, e venda direta pela internet, distribuição pelo correio e descarte final pelo usuário.

Será avaliado potencial risco no impacto ambiental e seus efeitos na saúde durante toda a sua fase de produção, como também durante se uso e na eliminação dos produtos.

A etapa mais detalhada será a da extração da seringa pois esta etapa está relacionada a preservação da floresta e valorização do trabalho dos seringueiros. Ou seja a dimensão ambiental e social da sustentabilidade.

Menos atenção será destinada ao descarte final, uma vez, como muito bem Manzini e Vezzoli apontaram, é difícil identificar como o consumidor se comporta em relação ao produto, durante o uso e no descarte final do produto no seu final de vida. 
- Quais os critérios de alocação de consumo/emissões em processos que geram mais de um produto?

No processo do couro vegetal não existe outros produtos. O látex colhido é todo utilizado na produção deste material.

\section{- Como o resultado será divulgado?}

Através de relatório de uso interno.

\subsection{2 - Análise de Inventário}

Na Análise de Inventário são descritas todas as fases do ciclo de vida inteiro do produto: a extração e transformação da matéria prima, a fabricação do produto e a distribuição, o uso, a estocagem, a reciclagem e o descarte.

A contabilização do processo se inicia na natureza com a extração e utilização de recursos naturais e também é finalizada na natureza expressa em resíduos e emissões geradas.

Para produção de artefatos em couro vegetal são realizadas as seguintes etapas:

1- Plantio, colheita, fiação e tecelagem do algodão

- Transporte do tecido até Boca do Acre e depois até a colocação

- Estoque

2- Extração da seringa na floresta

- Transporte até a colocação

3- Processamento para obtenção do produto

- Estoque 


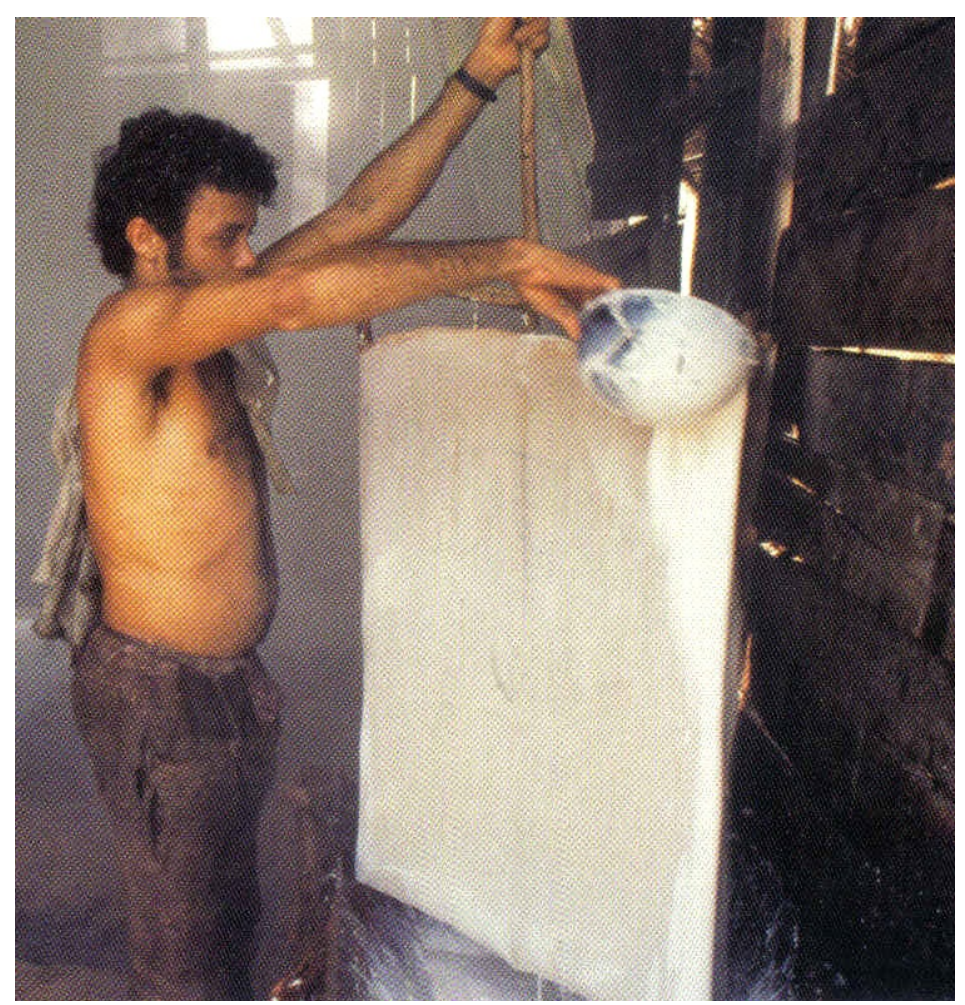

Figura 16: Foto de seringueiro banhando tecido de algodão com látex natural

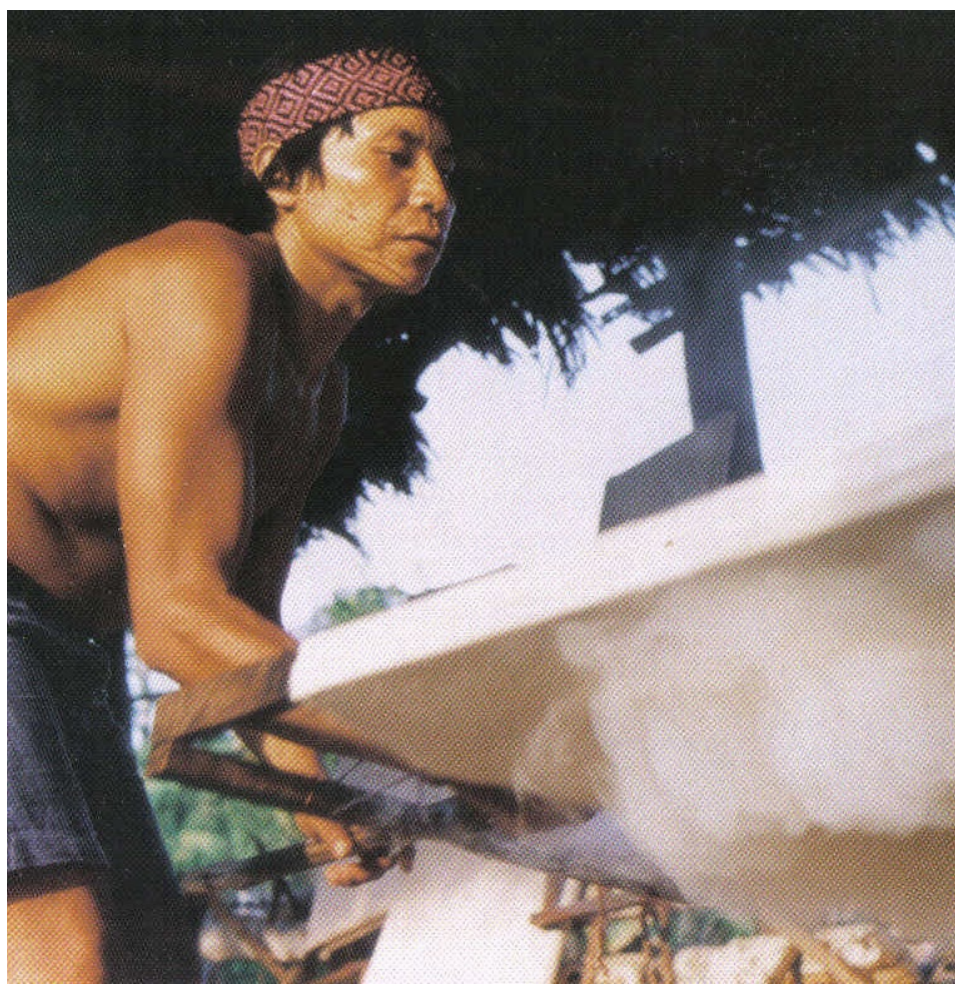

Figura 17: Foto de seringueiro defumando tecido de algodão em látex.
- Transporte da colocação até Boca do Acre, para Rio Branco e depois para o Rio de Janeiro.

- Estoque

4- Transformação do couro vegetal em produto na Confecção

- Estoque

- Embalagem

- Transporte para loja

5 - Venda

- Direta

- Internet

6 - Uso e manutenção

7 - Disposição final. 
Descrição das Etapas

Para coleta de dados com objetivo de elaboração do inventário foi realizada no dia 26 de outubro de 2006, no escritório da Brasil faz Design, uma entrevista com Maria Beatriz Saldanha, sócia gerente da empresa Amazon Life.

\section{1- Plantio, colheita, fiação e tecelagem do algodão}

O algodão é responsável por $10 \%$ da composição do couro vegetal.

O tecido de algodão é adquirido em sua maior parte da Tecelagem São Francisco de São Paulo.

As fases da produção do algodão são:

- Plantio, utilização de adubos e fertilizantes, defensivos, uso da terra e colheita.

- Transporte à tecelagem

- O algodão é estirado para ser transformado em fio.

- Enrolado em bobina

- Tecido

- Tingimento

Possíveis impactos negativos: uso de agrotóxicos, emissões poluidoras derivadas do tingimento, geração de resíduos sólidos.

Os rolos de tecido de algodão são transportados para de São Paulo para Boca do Acre - AM através de transportadora rodoviária e para a colocação por barco com motor à diesel. O diesel é adquirido pelo seringueiro em Boca do Acre. 
Este material é estocado na colocação.

\title{
2 - Extração da seringa na floresta
}

A extração do látex se dá sem a derrubada da árvore. A ação do homem na floresta só é visível através de minúsculos pontos espalhados - as clareiras que constituem as sedes das colocações.

\begin{abstract}
A marca da atividade extrativista são trilhas que atravessam a floresta sob a copa das árvores, e se as estradas fossem abandonadas, somente as cicatrizes dos numerosos cortes nos troncos de Hevea testemunhariam a longa história da borracha na floresta amazônica. (Enciclopédia da Floresta, 2002).
\end{abstract}

Recentemente foram criadas políticas dirigidas às reservas extrativistas reconhecendo o papel que a exploração da floresta por seringueiros desempenha na sua conservação. São valorizados os produtos dos seringueiros, como o couro vegetal, são estimuladas melhorias de qualidade com técnicas de processamento do látex e melhorias de produtividade na exploração da floresta como por exemplo através das ilhas de produtividade.

Após a sangria o látex está disponível em dois ou três dias e as árvores podem ser exploradas cerca de sessenta vezes por ano, durante decênios. Porém a extração é delicada e a sangria deve ser feita com cuidado. Uma pressão exagerada pode conduzir a uma deterioração do capital florestal. Não se corta em dias consecutivos, nem fora das leis de corte transmitidas pela tradição e reiteradas pelos planos de manejo. Não são permitidos roçados junto às estradas de seringa.

A extração exige prudência e abstenção: não sangrar demais, não abusar dos recursos sejam eles o látex, a caça, ou a mata bruta para roçados. Os ciclos e ritmos naturais devem ser respeitados. Os espaços criados no interior da floresta: pequenos roçados, piques 
de caça e estradas de seringas devem ser baixo impacto. Isto dá a estrutura básica do território de uma colocação, irradiando-se a partir da casa para dentro da mata bruta e ao longo de rios e igarapés, formando, por assim dizer, um esqueleto radial que delimita os estoques de plantas, animais e águas utilizados pelos seringueiros. As estradas de seringas são como túneis abertos na base das florestas: largas e limpas com escadas e pontes, raspadas com bandeiras, sempre reparadas para impedir sua reincorporação à natureza. Com 1 metro de largura, uma estrada de 10km de extensão representa cerca de 1 hectare de floresta que teve sua vegetação rasteira, e apenas ela, roçada para trânsito dos seringueiros. Apesar dos seringueiros trabalharem na formação e manutenção das estradas e das florestas e de seu entorno ao contrário do que acontece na agricultura, este trabalho não é reconhecida como benfeitoria.

As informações que seguem abaixo estão baseadas no Resumo Público de Certificação FSC - Programa Smartwood de Associação dos Produtores de Artesanato e Seringa - APAS em Boca do Acre, Amazonas.

Data da certificação e do Resumo Público de Certificação: 10/03/2005.

A certificação foi realizada em parceria com Instituto de Manejo e Certificação Florestal e Agrícola Imaflora de acordo com os padrões do SmartWood de SLIMF - Small and Low Intensity Managed Forests (Manejo Florestal em Pequenas Propriedades e de Baixa Intensidade). Para esta avaliação foi considerada a versão adaptada dos Padrões do FSC para Manejo Florestal em Terra Firme da Amazônia Brasileira, de março de 2002.

O Programa Smartwood é executado em nível mundial através dos membros institucionais (todos sem fins lucrativos) da Rede SmartWood que por sua vez é coordenada pela Rainforest Alliance, organização conservacionista sem fim de lucro com sede nos Estados Unidos da América. O programa SmartWood é aprovado pelo FSC - Forest Stewardship Council (Conselho de Manejo Florestal Mundial). Para receber a certificação 
de manejo florestal deve submeter-se a uma avaliação de campo. São realizadas auditorias anuais para monitorar as atividades de manejo florestal, para revisar o progresso da operação para cumprimento de suas condições de certificação e para verificar se os padrões de manejo são mantidos. A certificação é voluntária e realizada a pedido do interessado. O Imaflora é uma ONG certificadora e a única instituição no Brasil que realiza certificação, não só para empresas, mas também para comunidades seja ela indígena, de seringueiros, de ribeirinhos, etc. A certificação garante que a extração dos recursos florestais é feita de maneira ambientalmente correta, socialmente justo e economicamente viável.

Local da operação: Floresta Nacional Flona do Mapiá Inauní

Latitude: $07^{\circ} 57^{\prime} 39^{\prime \prime}$ a $08^{\circ} 41^{\prime} 54^{\prime \prime} \mathrm{S}$

Longitude: $67^{\circ} 42^{\prime} 02^{\prime \prime}$ a $68^{\circ} 38^{\prime} 50^{\prime \prime} \mathrm{W}$

As áreas de manejo se encontram distribuídas ao longo do IgarapéSão Francisco, dentro da Flona do Mapiá Inauiní e no seu entorno.

Não existe plantio. Olátex é extraído de seringueiras nativas (Hevea brasiliensis) através de processo manual de sangria.

Para estudo de caso foram consideradas as colocações certificadas pelo FSC. São ao todo seis que estão envolvidas na produção do couro vegetal, quatro dentro da Flona e duas em seu entorno. Quatro destas colocações possuem unidades de produção do couro vegetal e realizam manejo para extração do látex e produção de madeira para defumação das lâminas de couro vegetal. As outras duas colocações realizam o manejo apenas para a produção do látex de seringueira. A certificação de manejo florestal refere-se à extração do látex e da madeira.

O manejo para produção do látex segue o sistema tradicional extrativista na 
apenas com maior controle sobre a produção de cada estrada ${ }^{6}$ e numeração das árvores de seringueira para assegurar a certificação.

As etapas envolvidas no manejo para a produção do látex são, considerando as estradas já abertas: numeração e plaqueteamento (colocação de placas metálicas com número) das seringueiras, divisão das árvores em bandeiras ${ }^{7}$, raspagem das bandeiras e corte da seringueira.

Os meses de produção são de maio a agosto e de outubro a novembro, geralmente com uma estrada sendo cortada uma vez a cada três dias.

No extrativismo não são utilizados adubos ou fertilizantes. A floresta é manejada de acordo com o conhecimento tradicional dos seringueiros.

\section{3 - Processamento para obtenção do produto}

O couro vegetal é um produto derivado do aperfeiçoamento do saco encauchado, um tecido impermeabilizado pelo látex tradicionalmente usado pelos seringueiros como embalagem para transporte de látex e de bagagens especiais. O processo de aperfeiçoamento foi realizado pela empresa Couro Vegetal daAmazônia que, quando produziu as primeiras peças com este material verificou que os mesmos ficavam "melados" após o uso.

A Couro Vegetal da Amazônia solicitou pedido de invenção pela melhoria tecnológica do processo que permitiu maior estabilidade do látex pela vulcanização (processo de modificação da borracha natural obtida pela sua combinação com enxofre, para atribuirIhe maior força, elasticidade e resistência a temperaturas altas e baixas. Foram feitos três pedido: em 1993 (deferido), 1994 (indeferido) e 2000 ( aguardando avaliação).

${ }^{6}$ Estrada: estrada de seringa. Ex.: João tem duas estradas. (Enciclopédia da Floresta)

${ }^{7}$ Bandeiras: áreas dos troncos onde serão feitos os cortes. 
Resumo do pedido de patente ainda não avaliado:

\section{Processo e Composição para Obtenção de Tecido Emborrachado}

A presente invenção se refere a um processo e a uma composição, contendo látex, para a fabricação de lâminas de tecido emborrachado. O processo da presente invenção consiste nas etapas de formulação da composição; ciclos sucessivos de impregnação e defumação; e maturação. Também faz parte do escopo da presente invenção uma composição de impregnação que consiste essencialmente em uma solução aquosa contendo látex, fonte de enxofre e acelerador de vulcanização. As lâminas de tecido emborrachado obtidas da presente invenção podem ser submetidas a processos subseqüentes de manufaturamento para a fabricação de bolsas, malas, valises, vestimentas, agendas, carteiras, sapatos, e outros artefatos usuais em couro.

Antes deste pedido de patente outro pedido já havia sido analisado porém indeferido. O indeferimento daquele PI foi baseado no artigo 8 da LPI (Lei de Propriedade Industrial $-9.279 / 96)$

Art. 8o.- É patenteável a invenção que atenda aos requisitos de novidade, atividade inventiva e aplicação industrial.

Para o antropólogo professor da Unicamp, Mauro Almeida, não haveria inovação em um processo que envolve defumações e vulcanizações, que são operações já muito conhecidas pelo homem.

Resumo do pedido de patente indeferido:

Aperfeiçoamento em Processo de Beneficiamento de Tecido Emborrachado para Produção de Lâminas de Couro Vegetal compreendendo a adição, de látex, de solução de potassa a $10 \%$ na proporção de $0,4 \%$ sólido sobre o peso seco de borracha no látex, 
e adição, visando à efetivação da vulcanização e proteção à borracha, ao látex, de ingredientes obedecendo à seguinte formulação em peso: borracha seca (100), enxofre (1), óxido de zinco $(0,5)$, BDC (dibutil ditiocarbonato de zinco), antioxidante do tipo fenol-estirenado, homogeneizado, peneirado e aquecido a $45^{\circ} \mathrm{C}-50^{\circ} \mathrm{C}$, para utilização no emborrachamento dos tecidos através de sucessivos banhos alternados com igual número de defumações seguidos das secagens em estufas e ao ar livre, pelos períodos adequados, e à lixiviação em água corrente.

Descrição da produção do couro vegetal feita por técnico do Imaflora:

\begin{abstract}
Apesar do processo de produção do couro vegetal ser simples, ele exige uma mão-deobra qualificada para obter um bom produto com boas características para comercialização. Basicamente o processo envolve banhos de um tecido de algodão com late, misturado a alguns produtos químico, como potassa e um agente vulcanizante. Após cada banho, a lâmina é exposta a fumaça e após cerca de 7 banhos, as grades com os tecidos emborrachados vão para uma estufa de alvenaria. Após a estufa, o produto passa por uma rápida lavagem e se encontra pronto para o transporte. Aqui acrescentase que antes do transporte fica estocado.
\end{abstract}

Descrição feita pelo pesquisador da Unicamp, o economista Alexandre Goulart de Andrade:

\begin{abstract}
A produção do couro vegetal é um trabalho familiar, realizada por unidades domésticas, sendo que cada unidade envolve de seis a dez famílias. A atividade dos produtores é realizada em duas fases. Primeiro, recolhe-se o látex nos seringais da floresta, e uma vez feita a extração, o material é levado para o terreno de suas casas. Nesse terreno, existem dois espaços necessários para obtenção do couro vegetal: o defumador, onde o látex é envolvido em algodão e defumado, e uma estufa, para onde as tiras são vulcanizadas a altas temperaturas, usando-se lenha como combustível. Após essa última etapa, a tira ganha uma certa consistência e está feito o couro vegetal.
\end{abstract}

Segundo recomendações da certificadora deveriam ser implementadas melhorias no sistema de defumação das lâminas para minimizar a exposição dos produtores à fumaça. Deveria ser garantida a destinação adequada para o lixo/resíduos do manejo florestal e outros resíduos perigosos gerados na colocação. 
A produção é sazonal sendo realizada de maio a dezembro.

O desperdício no manuseio e mistura do produto químico com o látex é pequeno.

Na realização do banho de látex no algodão é pequeno.

No controle de qualidade APAS se aproveitam as lâminas refugadas como laminas de segunda e são produzidos produtos para o mercado local.

- Estoque na colocação

- Transporte da colocação até Boca do Acre. O transporte é feito por barco á motor á diesel. Lá é estocado na APAS que também realiza controle de qualidade.

- Transporte Boca do Acre até Rio Branco de caminhão.

- De Rio Branco até o Rio de Janeiro por transportadora rodoviária tercerizada

\section{4 - Transformação do couro vegetal em produto}

- Estoque dos componentes no galpão da Amazon Life:

Lâminas de couro vegetal e material complementar: tecido de algodão para forro e etiqueta impressa da tecelagem São Francisco, jeans já tingido da Santista, fivelas e ferragens da Altero, imãs da Eberle, zíper de nylon e algodão da YKK, espuma, papel cartão, selo da marca em borracha sintética da Plastitol.

- Embalagem individual em saco de tecido de algodão. Embalagem coletiva em caixa de papelão. 
- Transporte por caminhão à Diesel para a manufatura de confecção terceirizada no Rio de Janeiro

- Manufatura dos produtos

A manufatura é terceirizada na High Life.

Produção feita por costureiras através de corte e costura. Máquinas de costura elétrica. Ageração de resíduos pré-consumo é pequena por causa do corte que é otimizado. Às vezes material não aproveitado para exportação é utilizado para mercado local brasileiro.

- Transporte para loja no Leblon, RJ

Por caminhão à diesel

\section{Comercialização}

Em uma loja própria da marca no Rio de Janeiro.

A bolsa recebe uma segunda embalagem, um bolsa de papelão kraft impressa com a marca.

Venda por correio via Sedex.

Para exportação (Inglaterra, EUA, França, Itália, Noruega) através de embalagem coletiva da Fedex.

\section{Uso}

Manutenção: silicone

Não permite lavagem com produto químico pois danifica o material.

\section{Descarte}

Não está previsto nenhum destino específico no final de vida. O destino provável é que seja no em um aterro.

É biodegradável 
Considerando que as parte são unidas por costura é fácil separar as parte de diferentes materiais.

\section{Durabilidade Material}

De 3 à 10 anos dependendo do uso.

O couro vegetal tem a característica de ser um material de bom envelhecimento isto ajuda para um maior ciclo de vida do produto

Por ser um material natural o uso desgasta o material e a sua estética se transforma ganhando novos valores e significados sociais

\section{Possibilidade de conserto}

A empresa executa consertos na fábrica.

\section{Durabilidade de Estilo}

O design das peças não segue modismos sendo possível encontrar em linha os primeiros modelos desenvolvidos pela empresa.

Os design dos modelos não seguem o modelo de consumismo e de obsolescência programada sendo que a maioria dos usuários continuam a utilização do produto por longo período. 


\section{CONCLUSÃo}

O presente trabalho mostrou caminhos possíveis para o projeto de design sustentável apresentando-o como uma opção viável e desejável.

Seu objetivo foi o de sistematizar informações sobre sustentabilidade, apresentar características do meio ambiente e das políticas ambientais brasileiras, mostrando a possibilidade de interação do designer com esta realidade através do exemplo couro vegetal e da atuação da Amazon Life de maneira a criar exemplo de referência para atuação profissional do designer comprometido com o bem estar social e ambiental da sociedade. A isto foi somado um indicador de sustentabilidade ambiental , a ACV - Avaliação de Ciclo de Vida do Produto, uma ferramenta da área da engenharia, que se expressa através de um raciocínio e uma linguagem técnica e representa um importante instrumento para orientador de tomadas de decisões e neste sentido é desejável que o profissional de design se familiarize com o raciocínio do ciclo de vida produto pesando nos seus impactos desde a extração da matéria prima até seu descarte final

\footnotetext{
Potencialmente os designers podem dar contribuições significativas para o desafio da sustentabilidade desenvolvendo soluções que desafiem as anteriores e que demonstram possibilidades alternativas - mas para fazer isto precisamos transformar o ensino e a prática do design e desenvolver um novo entendimento da estética do produto e as noções de " bom design". ( Walker, 2006 ).
}

Os novos desafios se apresentam associados com a globalização do capitalismo industrial, disparidades sócio-econômicas nacionais e transnacionais e com os desenvolvimentos científicos e tecnológicos que acontecem rapidamente. É preciso encontrar novas idéias que rompam o convencional, que testem pré-conceitos, que redefinam as noções de design de produto e de cultura material pós-industrial.

Desenvolver produtos visando somente o mercado limita a atuação do design industrial e não estimula o enfrentamento de autenticas e importantes questões do nosso tempo: 
as responsabilidades éticas e ambientais da ação de cada um. É imperativo que sejam abordadas também questões de significado, identidade e cultura associada com bens materiais.

Para que novas idéias sejam significativas e inovadoras os designers deveriam receber educação em temas que vão além das tradicionais fronteiras do design como: Filosofia, Temas Históricos e Contemporâneos e discussões que estimulem o pensamento crítico.

Para Victor Papanek o futuro do design encontra-se associado ao papel fucral da síntese entre as várias disciplinas que constituem a matriz sócio-econômica-política dentro da qual o design funciona. À medida que avançamos no século XXI verifica-se a necessidade de designers especializados em design ecológico. Todavia toda educação deveria ser baseada em métodos e idéias ecológicos. Deveria incluir tanto estudos sobre o método científico como sobre biologia, antropologia, geografia e campos afins. A ecologia social e humana, bem como a filosofia e a ética deverão ser parte integrante desta formação.

Em geral jovens designers acreditam que a alta tecnologia possa alterar o equilíbrio ecológico. Esta preocupação se manifesta pelo desejo de um retorno a um estilo de vida simples e primitivo. Outros acreditam que precisamos ainda mais tecnologia para resolver os problemas criados pela própria tecnologia. Muitas respostas são provenientes de área associadas à alta tecnologia, como eletrônica, informática, circuitos integrados. Através da informática é possível analisar a destruição da camada de ozônio. Os satélites permitem compreender até que ponto a poluição, a desertificação, e as secas mudam o solo, os oceanos e o clima da Terra. Mas também através das ciências naturais como da antropologia, da geografia cultural e da geologia será possível chegar a indícios informativos sobre a verdadeira natureza das dificuldades que enfrentamos. Conhecimentos ainda mais profundos provirão de fontes biológicas, botânicas e biomórficas, assim como do estudo da história, da etnografia e da chamada "tecnologia antiga" . Estamos todos no 
e necessitamos de toda informação que conseguirmos obter. (Papanek, 1995)

\begin{abstract}
O designer trabalha, com algumas exceções para o mercado e responde à suas exigências. Os mercados são uma das instituições entre muitas: a governança democrática oferece o único esquema adequado à sua regulamentação (Sen, 2000). "Cada mecanismo de coordenação da sociedade - o Estado, o mercado, a comunidade - tem sua próprias falhas, mas cada um tem algumas vantagens únicas que podemos tentar combinar a fim de coordenar a correção das falhas (Bardhan, 2001).
\end{abstract}

O Estado nacional tem três funções principais:

a- A articulação de espaço de desenvolvimento, desde o nível local (que deve ser ampliado e fortalecido) ao transacional (que deve ser objeto de uma política cautelosa de integração seletiva, subordinada a uma estratégia de desenvolvimento endógeno);

b-A promoção de parcerias entre todos os autores interessados, em torno de um acordo negociado de desenvolvimento sustentável:

c - A harmonização de metas sociais, ambientais e econômicas, por meio do planejamento estratégico e do gerenciamento cotidiano da economia e da sociedade, buscando um equilíbrio. (Sachs, 2004, p.11)

O designeré um dos atores que interage na sociedade como um todo. Tem sido protagonista da chamada Revolução Industrial e do desenvolvimento dos produtos atuais muitos dos quais trazem benefícios reais ao consumidor e à sociedade e outros que respondem às exigências da indústria mas fica alienado em relação aos prejuízos que pode trazer sua atividade para o planeta quando por exemplo ao escolher para seu produto a madeira que destrói a floresta, utilizar recursos que não tem reposição e não se preocupa com sua reciclabilidade ou quando desenha carros sem se levar em conta a queima $\mathrm{CO}^{2}$ que vai para atmosfera aumentar o efeito estufa.

Vários seguimentos da sociedade têm se comprometido em encontrar soluções para um equilíbrio mais harmonioso entre homem e meio ambiente. O setor industrial é um deles. Depois de passado o momento que se acreditava que o problema estava no final do processo "end of pipe" a gestão ambiental tem mostrado a necessidade de atuar de forma preventiva, na origem dos problemas. 
Na origem de cada produto está a matéria prima e a sua extração. Saber escolher matérias primas de baixo impacto ambiental é um dos requisitos do design sustentável e saber tirar proveito das características da natureza brasileira é uma oportunidade de ganhar competitividade internacional. Acredito que com o exemplo do Couro Vegetal da Amazônia serviu para validar esta afirmação.

\begin{abstract}
"Um dos grandes méritos do Projeto Couro Vegetal daAmazônia é o de ensejar a modernização das relações em comunidades de floresta. É clara a mudança face do vínculo extremamente iníquo que costumava prevalecer entre o seringalista (o empresário da borracha) e os seringueiros e populações indígenas aliciadas para fazer o extrativismo do látex. Ficou para trás o tempo em que os seringalistas transformavam os trabalhadores da floresta em escravos por dívidas. " (Fujiwara e Alessio, 1998, p.18)
\end{abstract}

Um dos caminhos no Brasil para o design colaborar com o desenvolvimento sustentável, é tomar conhecimento da produção artesanal de comunidades tradicionais e agregar valor a seus produtos aumentando a geração de renda, gerando um,a relação de comércio justo, de maneira que os dois lados saia ganhando.

\footnotetext{
" Uma das propostas de desenvolvimento sustentável, alternativa à visão dominante do passado, é a do manejo florestal feito pelas populações tradicionais. O extrativismo vegetal, a caça e a pesca podem e devem ser aliados a mini-agroindústrias, a centros de produção artesanal ou a outros projetos de desenvolvimento comunitário. Uma alternativa que representa o abandono da idéia da super-estrada, para que se dê a abertura de variados caminhos - as pequenas trilhas, correndo pararelamente a um modelo de desenvolvimento que se submeta ao princípio da sociobiodiversidade. (idem. P.14)
}

O negócio sustentável é o que se caracteriza pela adoção de medidas que reduzem ao máximo o impacto ambiental no processo produtivo, por gerar benefícios sociais para as comunidades envolvidas e que com como base relações comerciais justas, que possibilitam a capacitação dos produtores, o repasse de tecnologias, o pagamento de royalties e investimentos sociais, (Alegretti, 2002)

Seria o design sustentável um conceito a ser desenvolvidos por algumas empresas e alguns designer esperançosos em transformar o mundo num espaço mais agradável do ponto de vista ambiental e socialmente mais justo ou como comprovam as últimas notí 
cias estamos atingindo o nível de tolerância da Terra, e estamos entrando numa era de catástrofes ambientais: 2007 será o ano mais quente da Terra com aquecimento médio de 0,5\%; haverá derretimento de geleiras e conseqüente aumento dos problemas no meio ambiente e estamos correndo o perigo de iniciar um processo em que populações de áreas críticas podem perder seu território e se transformar em "refugiados ambientais" e sendo assim é necessário que a nossa maneira de administrar o mundo mude radicalmente?

Sendo assimé necessário a participação de que todos para que a situação não se agrave ainda mais e que seja possível encontrar alternativas mais saudáveis para a vida humana e que o design não seja, como afirmava Papanek (1978, p.9). uma das profissões mais perigosas que existem, só perdendo para outra que engana mais: a publicidade, que se caracteriza por convencer pessoas a comprar coisas que não precisam, com dinheiro que não tem, de modo a impressionar pessoas com que não se importam. 


\section{Referências Bibliográficas}

Livros

EDWARDS, Brian. Guia Básica de la Sostenibilidad. Barcelona: Gustavo Pili, 2004.

MANZINI, Ezio; VEZZOLI, Carlo. O Desenvolvimento de Produtos Sustentáveis. São Paulo: Editora da Universidade de São Paulo, 2002.

MOURAD, Ana Lúcia; GARCIA, Eloísa Elena Corrêa; VILHENA, André. Avaliação do Ciclo de Vida: Princípios e Aplicações. Campinas: CETEA/CEMPRE, 2002.

RICARDO, Beto; CAPANILI, Maura (orgs). Almanaque Brasil Socioambiental. São Paulo: Editores, 2004.

SACHS, Wolfgang; REINHARD, Loske; LINZ, Manfred. Futuro Sostenibile. Bologna: Wupertal Institut - Editrice Missionaria Italiana, 1997.

HINTE, Ed Van; BAKKER, Conny. Trespassers: Inspirations for Eco-efficient Design. Netherlands Design Institute, Amsterdan: 010 Publishers, 1999.

VILHENA, André; POLITI, Elie. Reduzindo, Reutilizando, Reciclando: A Indústria Ecoeficiente. SãoPaulo: CEMPRE-CompromissoEmpresarial para Reciclagem: SENAI, 2000.

PAPANEK; Victor. Arquitetura e Design, Ecológica e Ética. Lisboa: Edições 70, 1995.

SACHS, Ignacy. Desenvolvimento Includente, Sustentável, Sustentado. Rio de Janeiro: Garamond, 2004. 
ROGERS, Richard; GUMUCHDJIAN, Philip. Cittá, perumpiccolo pianeta. Roma: Kappa, 1997.

WALKER, Stuart. Sustainable by Design, explorations in theory and practice. Rio de Janeiro: Garamond, 2004.

DEAN, Warren. A Luta Pela Borracha no Brasil, Um Estudo de História Ecológica. São Paulo: Nobel, 1989.

MANZINI, Ezio; JÉGOU, François. Quotidiano Sostenibile, Scenari di Vita Urbana. Milano: Edizione Ambiente, 2003.

IMAFLORA-Piracicaba. Brasil Certificado: A História da Certificação Florestal no Brasil. São Paulo: Imaflora, 2005.

VILHENA, André; GARCIA, Eloísa; MOURAD, Anna. Avaliação do Ciclo de Vida: Princípios e Aplicações. Campinas: CETEA/CEMPRE, 2002.

KAZAZIAN, Thierry (org). Haverá a Idade das Coisas Leves, Design e Desenvolvimento Sustentável. São Paulo: Editora Senac, 2005.

MARCHESE, Daniela. Eu Entro Pela Perna Direita: Espaço, Representaçãoe ldentidade do Seringueiro no Acre. Rio Branco: Edufac, 2005.

SOUZA, Márcio. A Luta de Cada Um. São Paulo: Instituto Callis, 2005.

CARNEIRO DA CUNHA, Manuela; ALMEIDA, Mauro (orgs). Enciclopédia da Floresta, O Alto Juruá: Práticas e Conhecimentos das Populações. São Paulo: Companhia das Letras, 2002. 
RIBEIRO, Wagner C. (org). Patrimônio Ambiental Brasileiro. São Paulo: Editora da Universidade de São Paulo, 2003.

VIANA, Gilney; SILVA, Marina; DINIZ, Nilo (orgs). O Desafio da Sustentabilidade, Um Debate Socioambiental no Brasil. São Paulo: Editora Fundação Perseu Abramo, 2001.

\section{$\underline{\text { Catálogos }}$}

CENTRO SÃO PAULO DESIGN; FIESP/CIESP. Catálogo Prêmio Ecodesign. São Paulo, 2003.

DRABBE, Natascha. Refuse: Lê Design d'Aujourd'Hui Pour Environnement de Demain. Paris: Institut Néerlandais. 2000.

SALDANHA, Bia. Exposição Negócios para Amazônia Sustentável. Rio de Janeiro: Ministério do Meio Ambiente, Secretaria de Coordenação da Amazônia, 2002 - 2003.

WOLF, Brigitte; VOGGENREITER, Meyer. Design et Ecologie: Perspectives Pour un Avenir Ecologique. Saint Etienne, 2000.

\section{Padrões Internacionais}

ISO TR 14062, Integração de Aspectos Ambientais no Projeto e desenvolvimento do Produto. 


\section{Dissertações e Teses}

ALLEGRETTI, Mary Helena. Construção social de políticas ambientais: Chico Mendese o movimento dos seringueiros. Brasília, 2002. 811p. Tese de Doutorado em Antropologia. Universidade de Brasília.

MACIEL, Raimundo Cláudio Gomes. Ilhas de alta produtividade: inovação essencial para a manutenção do seringueiro nas reservas extrativistas. Campinas, 2003. 99p. Dissertação de Mestrado em Economia. Universidade Estadual de Campinas. Instituto de Economia.

ANDRADE, Alexandre Augusto Lopes Goulart de. Artesão da floresta. População tradicional e inovação tecnológica: o caso do "couro vegetal" na reserva extrativista do Alto Juruá Acre. Campinas, 2003. 174p. Dissertação de Mestrado. Universidade Estadual de Campinas. Instituto de Economia.

SÉRVOLO FILHO, Henrique José. Avaliação da resistência à tração de couro vegetal de tecido de algodão impregnado com látex de cinco cultivares de seringueira (Hevea spp.) e vulcanizado. Piracicaba, 2006. Dissertação de Mestrado. Escola Superior de Agricultura Luiz de Queiroz. Universidade de São Paulo.

MOUSINHO, Patrícia de Oliveira. Indicadores de desenvolvimento sustentável: modelos internacionais e especificidades no Brasil. Rio de Janeiro, 2001. Dissertação (Mestrado em Ciência da Informação) - Universidade Federal do Rio de Janeiro, Conselho Nacional de Desenvolvimento Científico e Tecnológico. 


\section{$\underline{\text { Relatórios }}$}

FUJIWARA, Luiz M.; e ALLESIO, Nelson L. N. O Projeto Couro Vegetal da Amazônia. Relatório de Visita de Campo. Rio de Janeiro: FGV - Fundação Ford - CVA S/A, 1999.

\section{Documento Público e de Eventos}

Ministério da Agricultura Pecuária e Abastecimento. Situação Atual e Perspectivas. Agenda de Trabalho. Câmara Setorial da cadeia Produtiva da Borracha Natural. 54p. 2006

ALBALGLI, Sarita. Interesse Global no Saber Local: geopolítica da biodiversidade. In: SEMINÁRIO SABER LOCAL/ INTERESSE GLOBAL: PROPRIEDADE INTELECTUAL, BIODIVERSIDADEECONHECIMENTOTRADICIONALNAAMAZONIA.MuseuParaense Emílio Goeldi, Cesupa, Belém, 10 a 12 de setembro de 2003. Disponível em <http://www. museu-goeldi.br.

Resumo Público de Certificação FSC. Programa Smart Wood de ASSOCIAÇÃO DOS PRODUTORES EM ARTESANATO E SERINGA - APAS em Boca do Acre, Amazonas, Brasil. Certificado: SW-FM/COC-NTFP1447. 2005.

SNUC - Sistema Nacional de Unidades de Conservação. Texto da Lei 9.985 de 18 de julho de 2000 e vetos da Presidência da Republica ao PL aprovado pelo Congresso Nacional. 


\section{Pesquisa na Internet}

www.ecotool.it. Acesso em 19/9/2006

www.amazonlife.com. Acesso em 24/8/2006

www.amazonlink.org/seringueira/couro_vegetal_quem.html. Acesso em 24/8/2006

http://www.inpi.gov.br/. Acesso em 31/01/2007

http://www.mma.gov.br/. Acesso em 31/01/2007

http://www.cspd.com.br/. Acesso em 9/01/2007

http://www.wwf.org.br/. Acesso em 10/10/2006

http://www.ambientebrasil.com.br/. Acesso em 3/10/2006

http://www.gta.org.br/. Acesso em 28/12/2006

http://www.funbio.org.br/. Acesso em 29/12/2006

http://www.imaflora.org/. Acesso em 10/10/2006

http://www.unb.br/. Acesso em 11/11/2006

http://www.pnud.org.br/home/. Acesso em 20/08/2006

http://www.fsc.org.br/. Acesso em 23/12/2006 